\title{
Geology and Paleoenvironment of the Oligocene Jebel Qatrani Formation and Adjacent Rocks, Fayum Depression, Egypt
}

U.S. GEOLOGICAL SURVEY PROFESSIONAL PAPER 1452
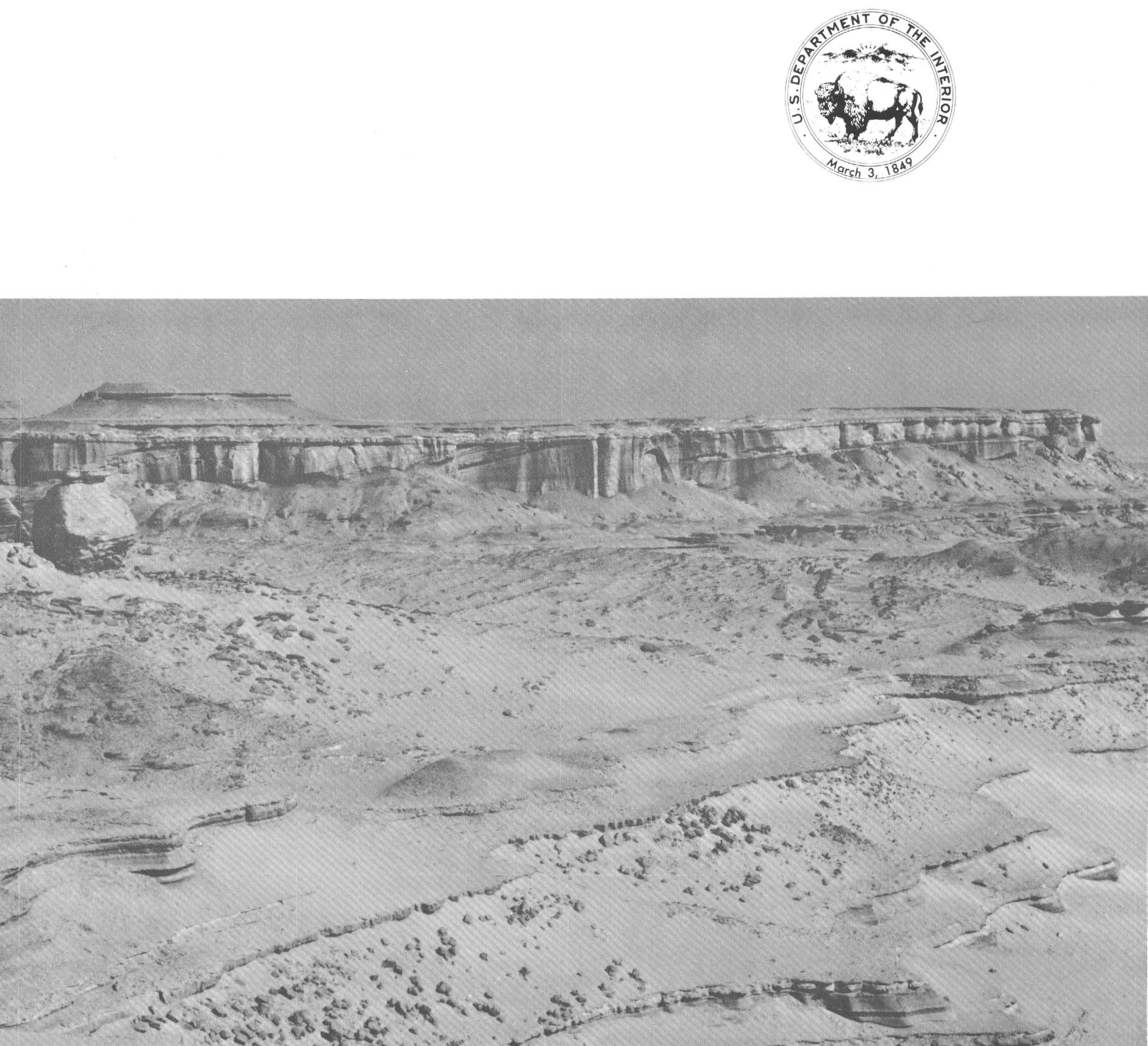
Front Cover: View to northeast of upper Eocene rocks of the Temple Member and the lower part of the Dir Abu Lifa Member of the Qasr el Sagha Formation, about $0.5 \mathrm{~km}$ northwest of the Qasr el Sagha Temple, Fayum Province, Egypt. 


\section{Geology and Paleoenvironment of the Oligocene Jebel Qatrani Formation and Adjacent Rocks, Fayum Depression, Egypt}

By THOMAS M. BOWN and MARY J. KRAUS

U.S. GEOLOGICAL SURVEY PROFESSIONAL PAPER 1452

Sedimentologic studies of lower Tertiary rocks in the Fayum Depression of Egypt clarify the alluvial environment and paleogeography of northern Egypt during the Eocene-Oligocene Tethyan regression and offer insights into the paleoenvironmental setting of the oldest known higher primates

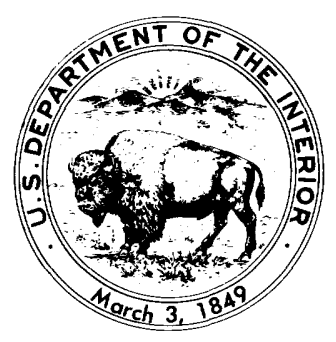




\section{DEPARTMENT OF THE INTERIOR \\ DONALD PAUL HODEL, Secretary}

\section{U.S. GEOLOGICAL SURVEY}

Dallas L. Peck, Director

\section{Library of Congress Cataloging in Publication Data}

Bown, Thomas $M$.

Geology and paleoenvironment of the Oligocene Jebel Qatrani Formation and adjacent rocks, Fayum Depression, Egypt.

(U.S. Geological Survey professional paper ; 1452)

Bibliography: $p$.

Supt. of Docs. No.: | 19.16:1452

1. Geology, Stratigraphic-Oligocene. 2. Geology, Stratigraphic-Eocene.

3. Geology-Egypt-Fayyum (Province) I. Kraus, Mary J.

II. Title. III. Series: Geological Survey professional paper ; 1452.

QE693.B68 $\quad 1986 \quad 551.7^{\prime} 85^{\prime} 09622 \quad 86-600277$

For sale by the Books and Open-File Reports Section, U.S. Geological Survey, Federal Center, Box 25425, Denver, CO 80225 


\section{CONTENTS}

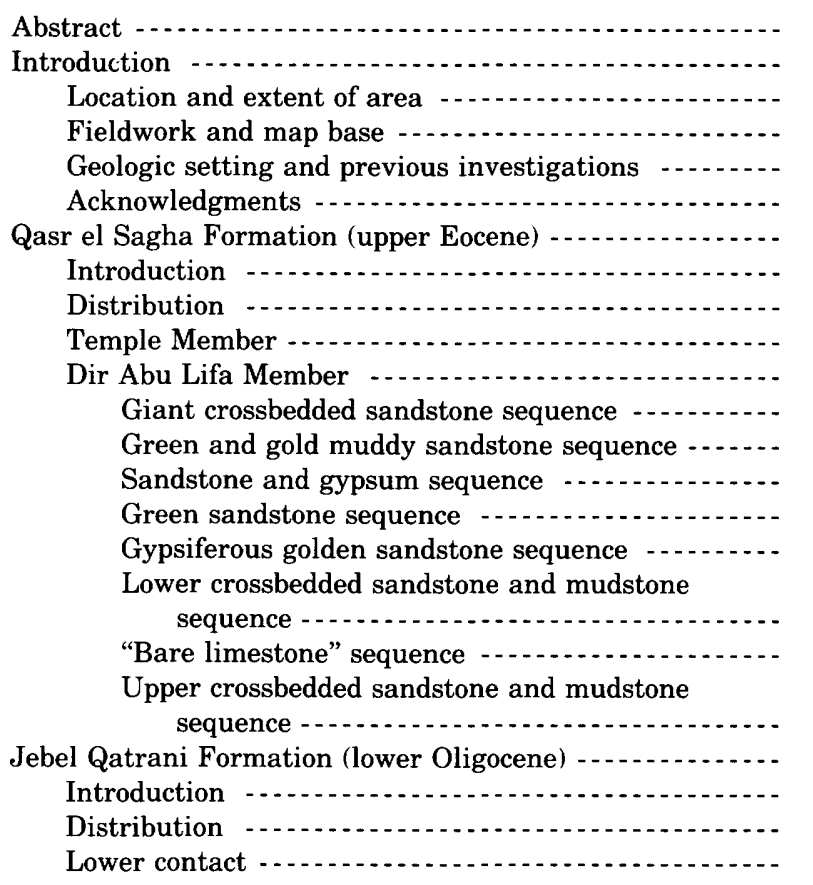

\begin{tabular}{|c|c|}
\hline Page & \\
\hline 1 & Jebel Qatrani Formation-Continued \\
\hline 2 & Lithology \\
\hline 2 & Lower sequence of Jebel Qatrani Formation ...... \\
\hline 2 & Barite sandstone \\
\hline 8 & Upper sequence of Jebel Qatrani Formation \\
\hline 9 & Chemical lithologies in the Jebel Qatrani \\
\hline 11 & Formation \\
\hline 11 & Gypsum \\
\hline 11 & Carbonates and flint \\
\hline 11 & Ironstone \\
\hline 12 & Paleosols \\
\hline 14 & Widan el Faras Basalt (upper Oligocene) \\
\hline 15 & Distribution \\
\hline 16 & Internal stratigraphy and age $\ldots \ldots \ldots$ \\
\hline 16 & Kashab Formation (Miocene) \\
\hline \multirow[t]{2}{*}{18} & Sedimentary environments \\
\hline & Qasr el Sagha Formation \\
\hline 18 & Jebel Qatrani Formation and younger rocks .......... \\
\hline \multirow[t]{2}{*}{19} & Alluvial system \\
\hline & Climate \\
\hline 20 & Depositional setting and paleogeography $\ldots \ldots$ \\
\hline 20 & Provenance \\
\hline 20 & References cited \\
\hline 20 & Glossary \\
\hline
\end{tabular}

\section{ILLUSTRATIONS}

Figure 1. Maps of northern Egypt, Fayum Depression, and Jebel Qatrani region, main study area, depicting natural landmarks and localities discussed in text . . . .

2. High-angle oblique aerial photographs of parts of the Qasr el Sagha Escarpment and the Jebel Qatrani and intervening areas in the northern part of the Fayum Depression, Egypt

3. Tertiary sequence in the Fayum area

4. Photograph of cliffs and benches developed on the Temple Member and the lower part of the Dir Abu Lifa Member, Qasr el Sagha Formation -

5. Stratigraphic column showing lithologies of the type section of the Dir Abu Lifa Member of the Qasr el Sagha Formation exposed in Wadi Efreet

6-17. Photographs showing:

6. North-dipping large-scale lateral accretion deposits within giant crossbedded sandstone sequence of the lower part of the Dir Abu Lifa Member of the Qasr el Sagha Formation - .

7. Giant crossbedded sandstone sequence of the Dir Abu Lifa Member of the Qasr el Sagha Formation with a channel scour truncating the lower part of the sequence

8. South-dipping lateral accretion deposits within giant crossbedded sandstone sequence in the lower part

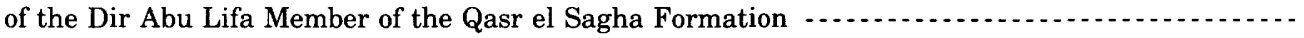

9. Green sandstone and gypsiferous golden sandstone sequences of the Dir Abu Lifa Member of the Qasr el

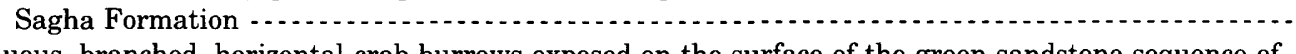

10. Sinuous, branched, horizontal crab burrows exposed on the surface of the green sandstone sequence of the Dir Abu Lifa Member of the Qasr el Sagha Formation 
FIGURES 11-17. Photographs showing:

11. Trace fossils from the Dir Abu Lifa Member of the Qasr el Sagha Formation and fossil fruit and wood from the Jebel Qatrani Formation

12. Gypsiferous golden sandstone sequence overlain by lower crossbedded sandstone and mudstone sequence

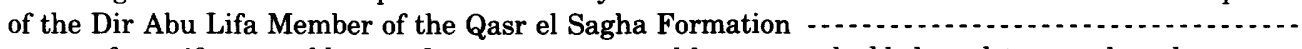

13. Exposures of gypsiferous golden sandstone sequence and lower crossbedded sandstone and mudstone sequence of the upper part of the Dir Abu Lifa Member of the Qasr el Sagha Formation ............

14. "Bare limestone" and upper crossbedded sandstone and mudstone sequence of the upper Dir Abu Lifa Member of the Qasr el Sagha Formation . . .

15. Hills capped with conglomerate of sedimentary iron ore, Bahariya Oasis, Western Desert of Egypt -...-

16. Conglomerate of sedimentary iron ore lying in scour developed on variegated fluvial rocks, Bahariya Oasis, Western Desert of Egypt

17. Rhizoliths at Sarab Mukhafet, western part of the Fayum Depression, Jebel Qatrani Formation .......

18. Diagram showing relations of units in the lower part of the Jebel Qatrani Formation in the region between Tel

Homar and a point on the Qasr el Sagha Escarpment -

19. Stratigraphic column showing lithologies, paleocurrent directions, and stratigraphic arrangement of fossil

vertebrate localities in units of the Jebel Qatrani Formation

20, 21. Photographs showing:

20. Bar tops exposed by deflation in the base of the middle gravelly sandstone sequence of the lower part of the Jebel Qatrani Formation

21. Fossil logs, lower part of the Jebel Qatrani Formation -

22. Rose density diagrams showing long axis orientations of fossil logs at two major concentrations in the lower part of the middle gravelly sandstone sequence of the lower part of the Jebel Qatrani Formation ............... 23-30. Photographs showing:

23. Rocks of the upper part of the lower Jebel Qatrani Formation showing epsilon crossbedding, channel scour, and ripup clasts

24. Rocks of the lower and upper variegated sequences of the lower part of the Jebel Qatrani Formation -..

25. Rocks of the lower green sandstone sequence of the lower part of the Jebel Qatrani Formation -.......

26. Rhizoliths of stump and root system of a small mangrove in the lower part of the Jebel Qatrani Formation at the head of Wadi Kadish, western part of the Fayum Depression . . . .

27. Rocks of the upper part of the lower Jebel Qatrani Formation and the lower part of the upper Jebel Qatrani Formation -..................

28. Natural cross section of small termitaria and gallery systems of a subterranean termite in fine to medium sand of middle variegated sequence in the upper part of the Jebel Qatrani Formation -...-

29. South-dipping epsilon cross stratification overlain by floodplain mudstones near base of lower variegated sequence of upper part of the Jebel Qatrani Formation -

30. Medium to coarse marine-mollusk-bearing green sandstone near top of upper variegated sequence of upper part of the Jebel Qatrani Formation

31. Stereophotographs of specimens of the trace fossil Ophiomorpha in the upper part of the Jebel Qatrani

Formation

32-39. Photographs showing:

32. Zone of calcium-carbonate-cemented sandstone at base of scour into less permeable rocks on southeast side of Tel Beradt-shay, middle variegated sequence of the upper Jebel Qatrani Formation ........

33. Rhizoliths in ironstone, Jebel Qatrani Formation -

34. Termitarium and entrance gallery of nest of subterranean termite (Termitichnus), in situ, in the upper

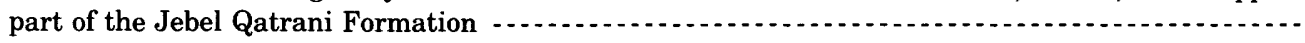

35. Rinizoliths in inceptisol, middle variegated sequence of upper part of the Jebel Qatrani Formation .....

36. Fragipan horizons in Jebel Qatrani paleosols

37. Exposures of upper variegated sequence of upper part of the Jebel Qatrani Formation and of Widan el Faras Basalt -........

38. Plane-bedded and large-scale cross-trough-stratified, medium to fine sandstones of alluvial Miocene

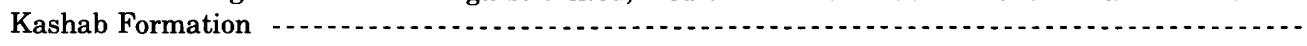

39. Curved tops of large-scale lateral accretion surfaces in the giant crossbedded sandstone sequence of the Dir Abu Lifa Member of the Qasr el Sagha Formation . . .

40. Diagram showing influence of buried Eocene and Oligocene anticlines on formation thicknesses, facies distributions, and trough of the principal early Tertiary Fayum Basin, northern Fayum Depression .................

41. Hypothetical depositional model for the Fayum Depression and adjoining areas of northern Egypt during the early

Oligocene

\section{TABLE}




\title{
GEOLOGY AND PALEOENVIRONMENT OF THE OLIGOCENE JEBEL QATRANI FORMATION AND ADJACENT ROCKS, FAYUM DEPRESSION, EGYPT
}

\author{
By Thomas M. Bown and Mary J. Kraus ${ }^{1}$
}

\begin{abstract}
Late Paleogene rocks in the Fayum Depression of northern Egypt consist of the nearshore marine and fluvial upper Eocene Qasr el Sagha Formation, the conformably overlying, dominantly fluvial Oligocene Jebel Qatrani Formation, and the Widan el Faras Basalt. In its type area, the upper part of the Qasr el Sagha Formation (Dir Abu Lifa Member) consists of 77 meters of nearshore marine sandstones and alluvial lateral accretion channel deposits that record sporadic but gradual late Eocene regression of the Tethys Sea and the western advance of alluvial plain conditions.

The Jebel Qatrani Formation is composed of about 340 meters of variegated alluvial rocks: fine to coarse sandstone, granule and pebble conglomerate, sandy mudstone, carbonaceous mudstone, and limestone. Most of these rocks show evidence of profound geochemical and mechanical alterations due to ancient soil (paleosol) formation. The lower part of the Jebel Qatrani Formation is dominated by coarse, multistory, multilateral sand bodies that record deposition by meandering streams under essentially quiescent tectonic conditions. In contrast, the upper part of the formation contains both a greater proportion of fine sandstone and mudstone and more discontinuous sand bodies. These attributes point to deposition in a more active tectonic setting, under the influence of an encroaching marine strandline. Nearshore marine conditions prevailed in some areas of deposition of the upper part of the Jebel Qatrani Formation, but this advance was both minor and short lived and was followed first by a return to alluvial deposition and then by regional erosion. This erosive episode might have been instigated by local uplift or by more regional tilting of the alluvial plain, and erosion was followed by increased tensional stress resulting in normal faulting and basalt extrusion (Widan el Faras Basalt). In the Jebel Qatrani area, the earliest basalt flows are dated at 31.0 \pm 1.0 million years (late early or early late Oligocene).

It is known that early and middle Eocene sedimentation in much of the Western Desert of Egypt consisted of the filling of synclinal basins that formed during the Late Cretaceous. By the end of the middle Eocene, most of these basins on the greater Tethyan shelf had been filled; however, this research suggests that an inner basin in the Fayum area aligned essentially west-southwest-east-northeast remained active, or at least continued to receive an extraordinary thickness of sediment during the late Eocene and early Oligocene. Because late Eocene-early Oligocene rocks thin markedly to the north and because paleocurrent data indicate deposition by principally west-flowing streams, the Fayum Basin was almost certainly isolated from the Tethys Sea on the north by highlands. Owing to these topographic constraints, streams during Dir Abu Lifa time and
\end{abstract}

1University of Colorado, Boulder, Colo. most of Jebel Qatrani time gained access to the Tethys Sea by flowing more or less westward, eventually debouching into coastal mangrove swamps in the vicinity of the El Bahr Depression.

Coarser clastics of the Dir Abu Lifa Member of the Qasr el Sagha Formation are dominated by medium- to fine-grained quartz sand, whereas those of even the lowest rocks of the Jebel Qatrani Formation show a major influx of distinctive second-cycle sediment (especially chert granules and pebbles) as well as primary clasts (including relatively unabraded feldspar crystals) derived from felsic igneous rocks. This evidence indicates that sediment sources for these rocks were much closer than the several hundred kilometers away in Upper Egypt that has been suggested by earlier workers. Paleocurrent data show that these source areas must have lain to the east of the Fayum Depression, probably in the vicinity of El Galala el Bahariya in the Eastern Desert.

In Oligocene times, the Fayum area was a tropical to subtropical lowland coastal plain characterized by an abundance and variety of vegetation. Mangrove swamps dominated the Oligocene coastline and gave way landward to a forested interior that supported many varieties of trees, large vines, legumes, marshy plants, and aquatic ferns. Many of these floral elements resemble tropical to subtropical species of the present-day Indomalaysian region. Paleosols show evidence of generally damp soil conditions but indicate that rainfall was probably seasonal (monsoonal). Freshwater limestones containing ostracodes and charophytes record the local formation of broad, shallow floodplain ponds. This forested coastal lowland was broken by several meandering streams which debouched westward and northwestward, a short distance away, into the Tethys Sea. The alluvial plain had little relief, and storms or tidal incursions introduced saline water into the streams for several kilometers inland, causing these waters to be cohabited by marine fish, sharks, skates, rays, mollusks, and crabs, as well as by crocodiles, sirenians, and freshwater turtles, fish, and mollusks. The Jebel Qatrani forest supported a large and varied vertebrate fauna dominated by rodents, browsing herbivores, carnivorous mammals, and arboreal quadrupedal higher primates. A large fauna of terrestrial invertebrates is recorded by trace fossils; those of wasps or bees, crayfish, ants, and subterranean termites are especially well represented.

In the Fayum area, the tropical to subtropical lowland coastal plain environment typical of the Jebel Qatrani Formation persisted well into the Miocene, and rocks of the dominantly alluvial Kashab Formation closely resemble those of the Jebel Qatrani lithologically. By latest Oligocene and early Miocene time, sedimentation had largely filled the Fayum Basin and streams were at last able to enter the nearby Tethys Sea directly from the south. Periodic and localized marine incursions typified the Miocene depositional regime until they finally prevailed in the middle Miocene with deposition of the marine Marmarica Formation in the northern part of the Western Desert. 


\section{INTRODUCTION}

\section{LOCATION AND EXTENT OF AREA}

This report pertains to research undertaken in an area approximately bounded by $29^{\circ} 24^{\prime}$ to $29^{\circ} 45^{\prime} \mathrm{N}$. latitude and $30^{\circ}$ to $30^{\circ} 45^{\prime} \mathrm{E}$. longitude, in the northern part of the Fayum Depression (Fayum Province) of northern Egypt (figs. 1,2). The most detailed work was accomplished in rocks exposed north of Birket Qarun, from the base of the Qasr el Sagha Escarpment on the south to the top of the Jebel Qatrani on the north, and from the large isolated butte (Tel Homar) on the west to Dir Abu Lifa on the east (figs. $1 C$ and 5). Several geologic reconnaissance surveys added supplementary information from more outlying areas of the Western Desert of Egypt, especially in areas to the north between Jebel Qatrani and Wadi Farîgh (fig. 1B) and areas to the west, between the Sarab Mukhafet (fig. $1 B$ ) and the Bahariya Oasis (Geological Survey of Egypt, 1981).

\section{FIELDWORK AND MAP BASE}

Fieldwork was accomplished over 10 months in 1980 , 1981, 1983, 1984, and 1985. Sections were measured with a Jacob's staff, and locality information in unsurveyed areas was obtained by compass triangulation. Few detailed small-scale topographic or relief maps of the Fayum area have been published. Map controls for physiographic features, localities mentioned in the text, and lines of measured sections in the principal report area (fig. $1 C$ ) were established using Beadnell (1905, plan XVIII), Gebel Qatrani Quadrangle (1:50,000, AMS series P773, sheet 5484 III), Qaret elGundi Quadrangle (1:50,000, AMS series P773, sheet $5484 \mathrm{II}$ ), and the Gebel Qatrani relief quadrangle map (1:100,000, Geological Survey of Egypt, 1956). Map controls for areas farther afield in the Western Desert of Egypt were obtained from Beadnell (1905, plan XVII), Bartholemew (1978), and Geological Survey of Egypt quadrangle maps of Cairo (1:500,000, 1940),

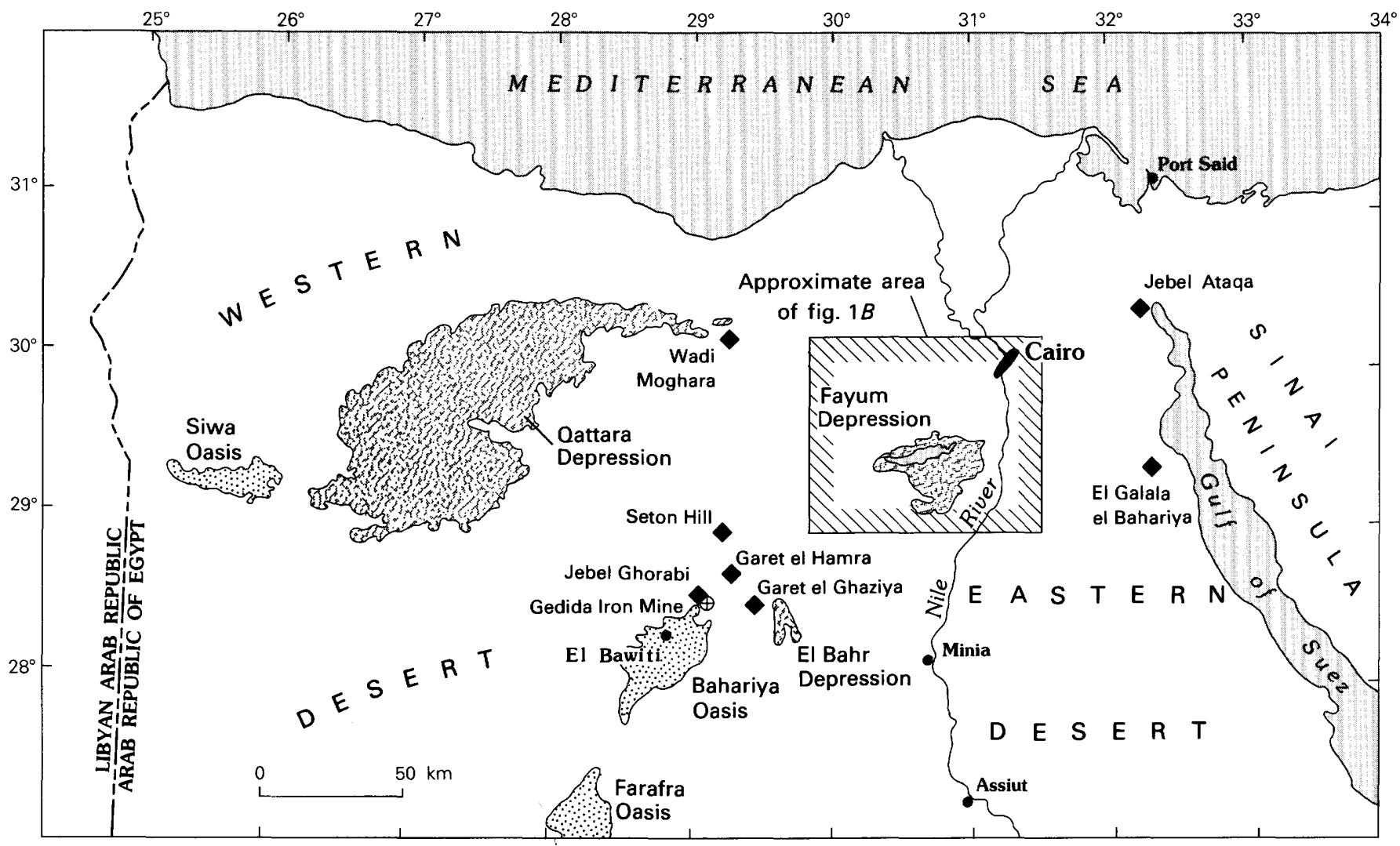

EXPLANATION

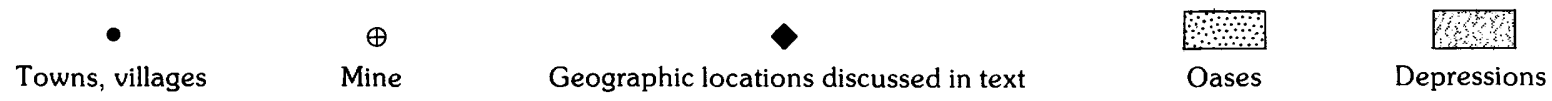

FiguRE 1A.-Map of northern Egypt depicting natural landmarks and localities discussed in text. 


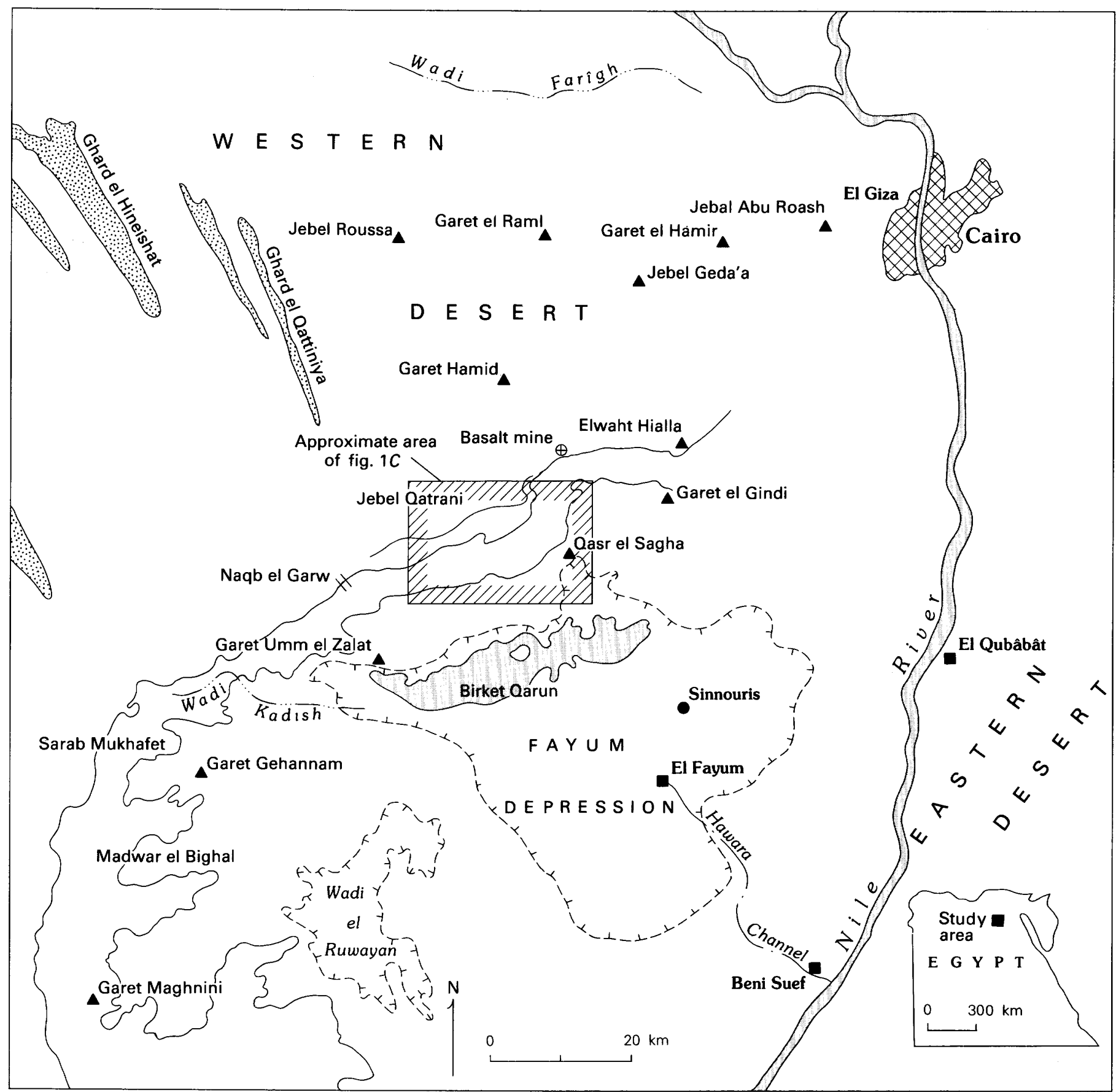

\section{EXPLANATION}

$\Delta$

Topographic landmark

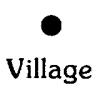

Major town

\section{$\infty$}

Metropolitan area

\section{$\oplus$}

Mine

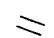

Pass
Escarpment line

$T-T-T-$

Sea level datum

(hachures in depression)

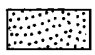

Seif dunes

Wadi (dry watercourse)

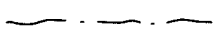

Canal

FIGURE 1B. - Map of Fayum Depression depicting natural landmarks and localities discussed in text. 


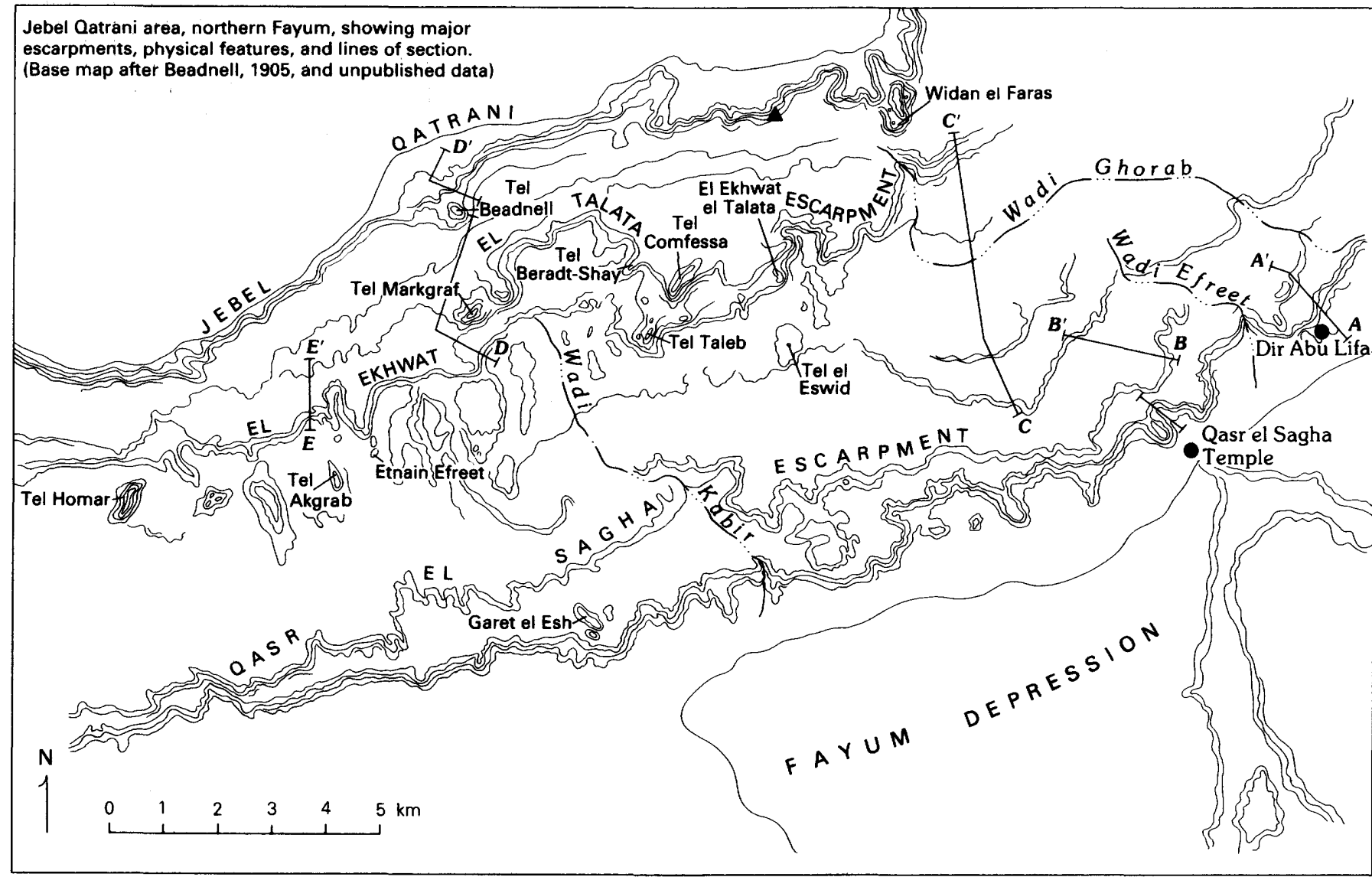

Escarpment lines

Dry watercourse (Wadi)

\section{EXPLANATION}

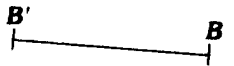

Lines of measured stratigraphic sections

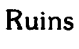

$\Delta$

Figure 1C.-Map of Jebel Qatrani region, main study area, depicting natural landmarks and localities discussed in text.

El Faiyum (1:100,000, 1938), Qaret Gehannam (1:100,000, 1945), and Wadi Farîgh $(1: 100,000,1945)$.

Because earlier geologic studies of the Fayum area lack detailed locality information, a great deal of attention has been given to as precise as possible locality data throughout the text. Because much of the Fayum area has not been mapped in detail, place names are lacking for many of the most prominent physiographic features (e.g., hills, mesas, and wadis). Many have had names applied to them here for ease of discussion and reference to maps. In all instances, these names have been drawn from the colorful Arabic language and existing local place name nomenclature has been retained for all features for which this nomenclature is
FIGURE 2.-High-angle oblique aerial photographs of parts of the Qasr el Sagha Escarpment and the Jebel Qatrani and intervening areas in the northern part of the Fayum Depression, Egypt. Illustrations $A$ through $F$ overlap from west to east and depict natural landmarks and localities discussed in the text. Numbers with arrows indicate locations of certain other photographic illustrations, as well as the direction in which the photograph was made. The scale is accurate for the lower half of the photograph only; the upper part is foreshortened. $A$, Region west of the Alexandria Trail, showing poor exposures of a barite sandstone sequence and thinning of the Jebel Qatrani Formation across a buried anticline beyond the west margin of the photograph (compare lines $A-A^{\prime}$, thinner, and $B-B^{\prime}$, thicker). $B$, Region of Naqb el Garw and the Alexandria Trail, showing exposures of the barite sandstone.

Geologic contacts for $2 A-F$ are approximate and are depicted as follows: Tmk=Kashab Formation (lower Miocene); Tomw=Widan el Faras Basalt (upper Oligocene); Toj=Jebel Qatrani Formation (lower Oligocene); Teq=Qasr el Sagha Formation (upper Eocene). 

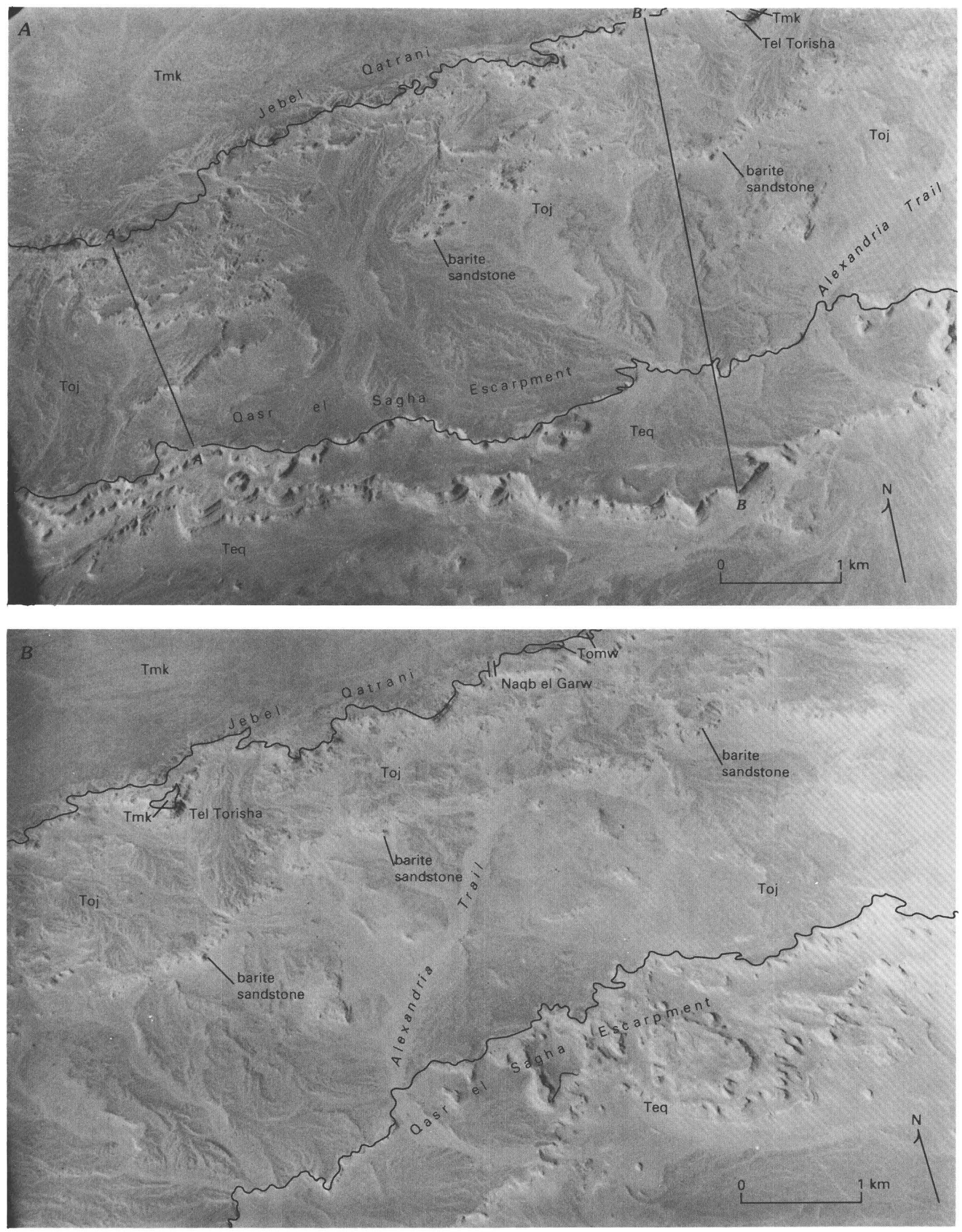

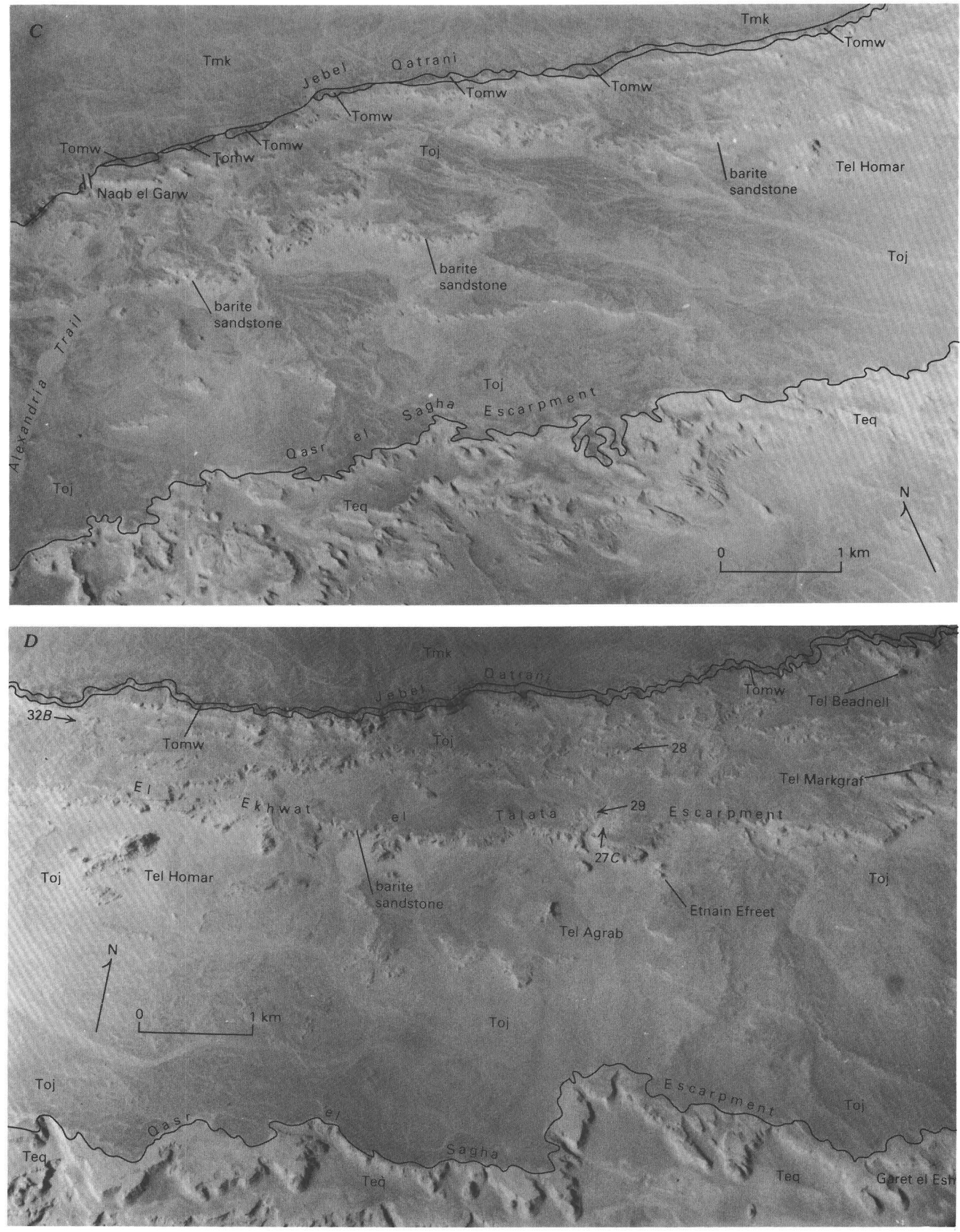

FIGURE 2.-Continued. $C$, Region between Naqb el Garw, and Tel Homar showing exposures of the barite sandstone. $D$, Region between Tel Homar and Tel Markgraf showing exposures of barite sandstone. 

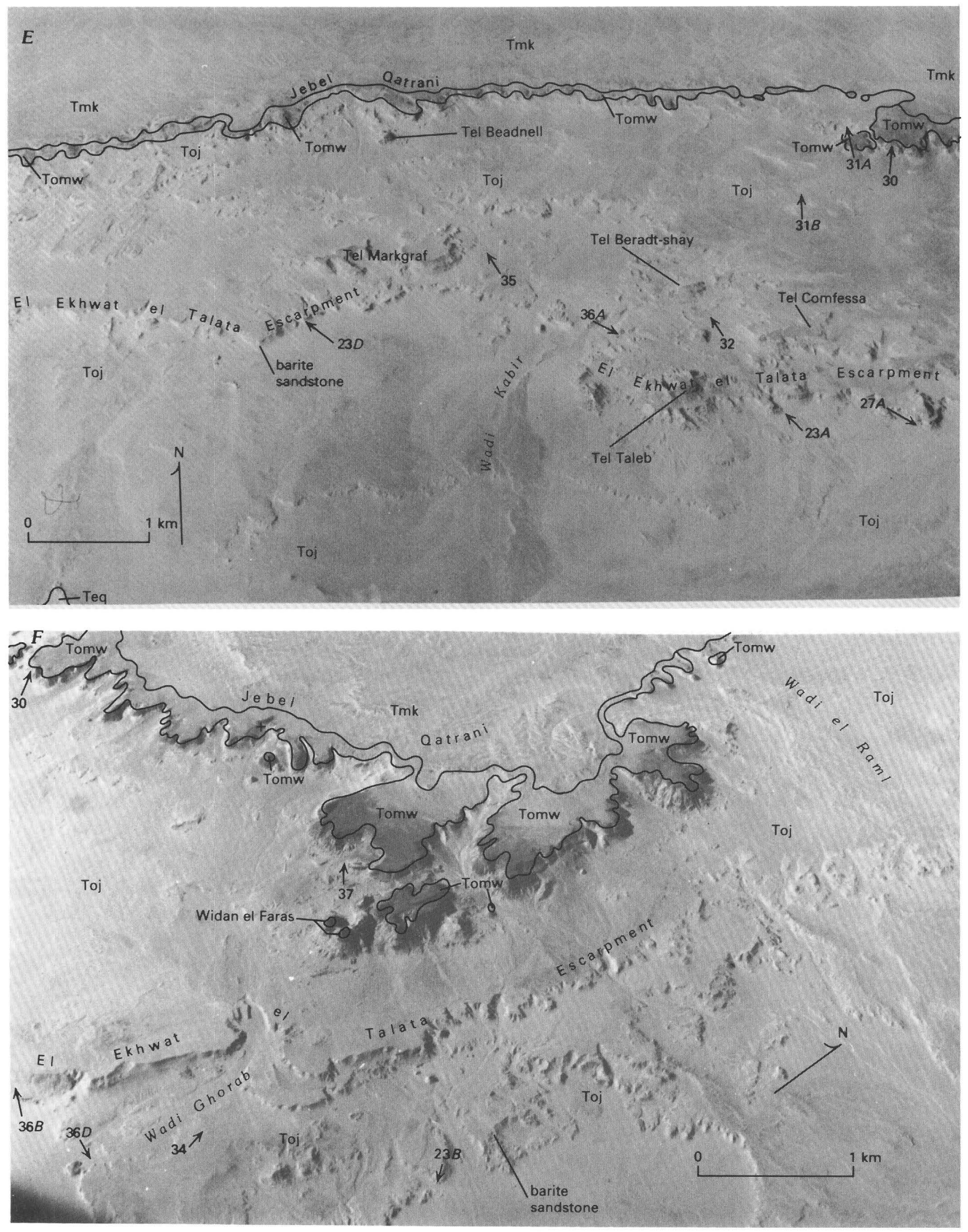

Figure 2.-Continued. E, Region of Tel Markgraf-Tel Beadnell-Tel Homar. $F$, Region of Widan el Faras, with Widan el Faras Basalt clearly outlined as a black band at the top of Jebel Qatrani. The location of the dated basalt sample $(31.0 \pm 1.0 \mathrm{Ma})$ is denoted by a cross $(+)$. 
known. English transliteration of Egyptian place names and names of geologic units varies considerably in the older literature. The usages employed in this report conform, as well as we have been able to determine, with those currently sanctioned by the Geological Survey of Egypt. Etymologies for certain Arabic words and place names that appear commonly in the text are provided in the "Glossary."

\section{GEOLOGIC SETTING AND PREVIOUS INVESTIGATIONS}

The Fayum Depression is a roughly triangular region occupying about $12,000 \mathrm{~km}^{2}$ adjacent to the Nile Valley in the Western Desert of Egypt (fig. 1A, $1 B$ ). The Fayum consists of a small cultivated area (about $1,800 \mathrm{~km}^{2}$; Beadnell, 1905) that is surrounded by a much larger expanse of desert on the south, west, and north. The desert in the south and southwest parts of the Fayum Depression contains the El Gharaq Basin and the self-contained Wadi Muela and Wadi el Ruwayan depressions (Beadnell, 1905). The western part of the Fayum Depression is made up of desert serir and minor amounts of dune sand in a large topographic basin which is bounded on the west by a low escarpment between Garet Maghnini and Wadi Kadish (fig. $1 B$ ). This escarpment is a southern salient of a much more prominent cliff, the Qasr el Sagha Escarpment, that trends east-northeast from Wadi Kadish to Elwaht Hialla (fig. $1 B$ ), and that forms the northern boundary of the Fayum Depression. Farther north, and above the Qasr el Sagha Escarpment, are two higher scarps-a lower one, here termed the El Ekhwat el Talata Escarpment, and above it the Jebel Qatrani (fig. 2). Beyond the low escarpment at the west end of the depression as well as to the north, beyond the Jebel Qatrani, the desert is composed of essentially featureless serir and dune sand. On the east, a low desert ridge 5-12 km wide separates the Fayum Depression from the Nile Valley for about $50 \mathrm{~km}$ between the villages of Beni Suef and El-Qubâbât (fig. $1 B$ ).

Birket Qarun (fig. $1 B$ ), a saline lake, occupies about $220 \mathrm{~km}^{2}$ of the lowest part of the Fayum Depression; its surface lies $44 \mathrm{~m}$ below sea level and it is the largest lake in Africa north of the Sahara. The present lake is much smaller than its former extent in prehistoric times (Caton-Thompson and Gardner, 1934); irrigation of the cultivated area and the level of the lake were regulated in Dynastic through Ptolemaic times by means of the Bahr Youssef (Hawara Channel, fig. 1B), which connects the lake with the Nile River. The origin of the Fayum Depression is conjectural, but, like the larger Qattara Depression (fig. 1A ) some $300 \mathrm{~km}$ to the west-northwest, it is believed to have been excavated by subaerial erosion (probably deflation) during the
Pleistocene. Beadnell (1905) gives a much fuller account of the topography and geography of the Fayum Depression.

Approximately $815 \mathrm{~m}$ of middle Eocene through late Oligocene rocks are exposed in the Fayum Depression. The middle Eocene sequence is largely nearshore marine and shallow shelf in origin (Said, 1962); it is best exposed in badlands developed in the southern and western parts of the depression, in the areas of Wadi el Ruwayan and Garet Maghnini and beneath Garet Gehannam (fig. $1 B$ ), and to the northeast in the region surrounding Garet el Gindi. Nearshore marine upper Eocene rocks form the top of Garet Gehannam and most of the lowest escarpment bounding the Fayum Depression on the west, northwest, and north. These rocks are especially well exposed at Madwar el Bighal, in the lower drainage of Wadi Kadish, on the Qasr el Sagha Escarpment, and at the base of Elwaht Hialla (figs. $1 B, 1 C$; also see Beadnell, 1905, plates XIX, XX, XXII). Oligocene terrestrial rocks are largely confined to the Jebel Qatrani and the El Ekhwat el Talata Escarpment (fig. $2 E$ ); however, these rocks persist as far west as the head of Wadi Kadish and the divide separating the Fayum Depression from the Western Desert serir (between Madwar el Bighal and the Sarab Mukhafet; fig. 1B). An unknown thickness of Miocene terrestrial and fluvio-marine rocks is poorly exposed at the top of Jebel Qatrani and in and around Wadi Farîgh, and probably extends continuously to the northwest some $160 \mathrm{~km}$ to Wadi Moghara.

From youngest to oldest, the Tertiary sequence in the Fayum area is shown in figure 3. Structurally, the Fayum Depression lies within the southern shelf region of the early Tertiary Tethys Sea. Early Tertiary and Miocene rocks there dip gently $\left(1^{\circ}-5^{\circ}\right)$ north or north-northwest, except where they have been affected by local faulting or by local anticline and syncline development. The major faults are normal and are generally confined to the Qasr el Sagha, El Ekhwat el Talata, and Jebel Qatrani Escarpments where, in the main, they trend essentially east-west, with downthrown blocks generally on the southern side. Displacement rarely exceeds $25 \mathrm{~m}$. A few noteworthy normal faults that trend northwest-southeast displace rocks on the Qasr el Sagha Escarpment at Garet el Esh (fig. 1C) and a few kilometers to the west of there. Major folds formed in and near the Fayum Depression both before and during deposition of the early Tertiary rocks. At Jebel Abu Roash (fig. $1 B$ ) is a major anticline that existed prior to deposition of the Qasr el Sagha Formation (Salem, 1976), and several parallel folds between the basalt mine and Elwaht Hialla (fig. $1 B$ ) were active during or immediately prior to deposition of the Jebel Qatrani Formation. Other buried folds, probably active 


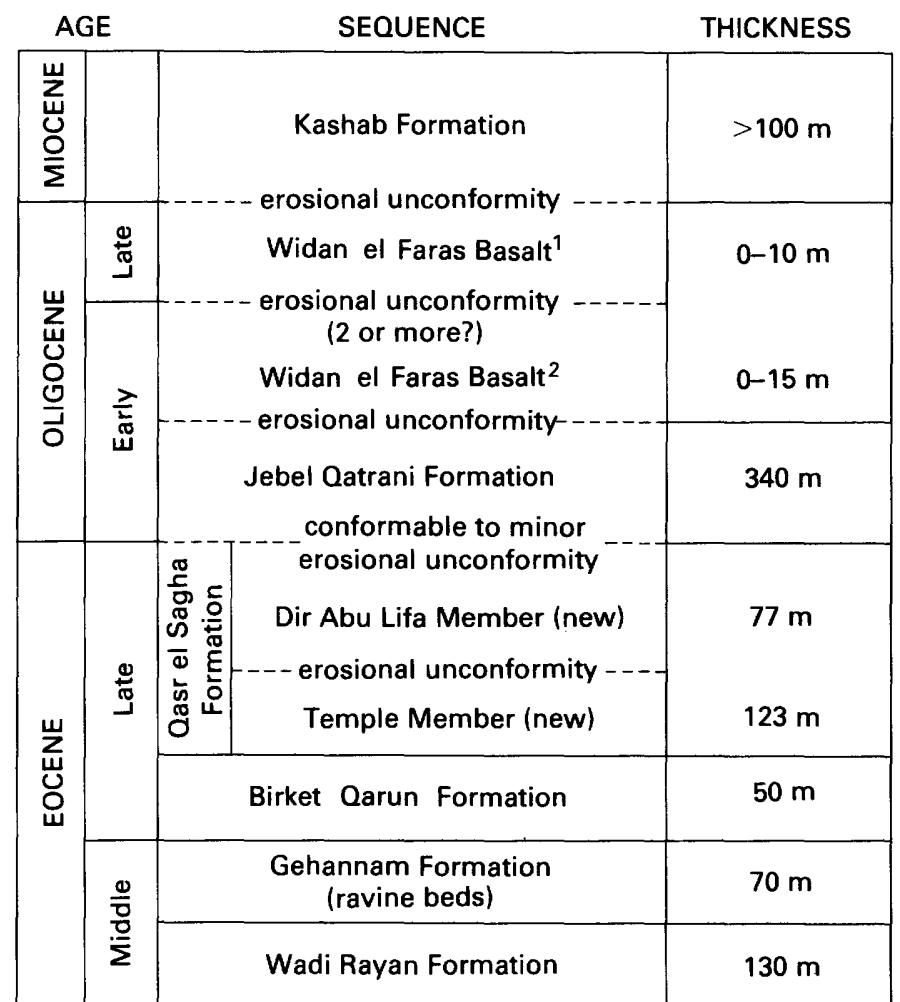

$124.7 \pm 0.4 \mathrm{Ma}$

$27.0 \pm 3.0 \mathrm{Ma}$

$231.0 \pm 1.0 \mathrm{Ma}$

FIGURE 3.-Tertiary sequence in the Fayum area (from Beadnell, 1905, as modified by Said, 1962, Vondra, 1974, Bowen and Vondra, 1974, Bown, 1982, and this paper).

during lower Oligocene deposition, occur in the area between the Alexandria Trail and Wadi Kadish (fig. $2 B$ ).

The early Tertiary of Egypt is perhaps best known for its large and diverse fossil mammal fauna, first recorded by Schweinfurth's 1879 discovery of Eocene whale remains and later marked by recovery of the first Oligocene continental mammals from Africa (e.g., Andrews, 1901, 1903, 1906; Beadnell, 1901, 1902). The Oligocene Jebel Qatrani Formation became especially noteworthy for discovery of abundant new remains of the earliest Old World higher primates, described most recently by E.L. Simons and his colleagues (e.g., Simons, 1961, 1962, 1974; Fleagle and others, 1975; Simons and Kay, 1983), and for recovery of the first known African marsupials (Bown and Simons, 1984; Simons and Bown, 1984) and African tarsioid primates (Simons and Bown, 1985).

From 1961 to 1968, and pursuant to the paleontological work of Simons and the Cairo Geological Museum, geological studies of the Jebel Qatrani Formation and the underlying upper Eocene Qasr el Sagha Formation were undertaken by C.F. Vondra and his students.
These studies (e.g., Vondra, 1967, 1971, 1974; Bowen, 1971; Bowen and Vondra, 1974) described deltaic and other nearshore paleoenvironments of the Qasr el Sagha Formation and established the largely alluvial depositional setting of the Jebel Qatrani Formation (termed "fluvio-marine beds" by Beadnell, 1905).

Under the auspices of the Geological Survey of Egypt and the Cairo Geological Museum, a second phase of recent paleontological operations in the Fayum area was initiated by E.L. Simons at Duke University and B. Issawi of the Geological Survey of Egypt in 1977. This research effort continued until 1983 and in 1984 and 1985 was carried out cooperatively with the General Petroleum Company of Egypt. In conjunction with these studies, geologic research was renewed by geologists of the Geological Survey of Egypt and by us. These efforts have led to considerable advances in understanding the geology, paleoecology, and paleogeography of the early Tertiary of northern Egypt and the physical setting of the late Eocene and Oligocene fossil mammal faunas of the Fayum region. In the last 6 years, this research has emphasized (1) physical stratigraphy and biostratigraphy, (2) fluvial sedimentology, (3) paleopedology (fossil soils), (4) vertebrate taphonomy, and (5) vertebrate and invertebrate paleoichnology (trace fossils).

A preliminary report of recent findings in most of these subjects was presented by Bown and others (1982), and a survey of the trace fossils of the Jebel Qatrani Formation documented the first such assemblage from the continental Tertiary of Africa and described the first ichnofossils of subterranean termites (Bown, 1982). Current research on upper Eocene and Oligocene rocks of the Fayum Depression by many workers stresses not only the fossil vertebrates, trace fossils, and physical geology, but also newly discovered fossil leaf, fruit, and seed floras (Wing and Tiffney, 1982), palynology, and invertebrate fossils.

A summary of pertinent geological investigations in the Fayum region is presented in table 1.

\section{ACKNOWLEDGMENTS}

We thank P.D. Gingerich, E.L. Simons, and S.L. Wing for technical review of this paper, and J.G. Fleagle, P.D. Gingerich, B. Issawi, L.T. Middleton, D.T. Rasmussen, E.L. Simons, C.F. Vondra, and S.L. Wing for much informative discussion. B. Issawi, A. Kandil, A. Shellaby, and M. Askalany of the Geological Survey of Egypt and H. Kamal and A. El-ostaz of the General Petroleum Company of Egypt were instrumental in providing geological and logistical support in the field, and we are grateful to E.L. Simons for inviting us to participate in five expeditions to the Fayum Depression. In the field, we were ably assisted in our studies 
TABLE 1.-Historical summary of pertinent geological investigations of Tertiary rocks in the northern Fayum Depression and related areas of Egypt

1845

1848

1859

1879

1901-05

1901-04

1905-06

1906-07

1961-67

1962

1968

1974

1976

1977-85

1980

1981

1982
A.B. Orlebar first described fossil trees from rocks of the Jebel Qatrani Formation at Ma'adi (Cairo).

L. Newbold described the fossil forest at Ma'adi in greater detail and noted other occurrences of fossil wood in Egypt from the Jebel Qatrani and Kashab Formations.

F. Unger first suggested that the fossil forests of Egypt are allochthonous and were derived from forested areas far south of where the fossil logs now lie, initiating the concept of an early Tertiary north-flowing "Protonile" River.

Schweinfurth discovered the first fossil vertebrates in the Fayum Depression (whale remains from the island Geziret el Qorn in Birket Qarun), published in 1882 by Dames.

H.J.L. Beadnell (1901) published a reconnaissance geological survey of Tertiary rocks in the Fayum area in which he first described the "bone beds" of the Jebel Qatrani Formation. This was followed by his two classics; "The Cretaceous Region of Abu Roash" (1902) and "The Topography and Geology of the Fayum Province of Egypt" (1905), which first described in detail the Eocene and Oligocene rocks discussed in this report.

C.W. Andrews of the British Museum recovered the first large collections of fossil vertebrates from the "bone beds" of the Jebel Qatrani Formation.

John Ball and Beadnell published "Baharia Oasis: Its Topography and Geology," offering some correlations of Eocene and younger rocks with those of the Fayum Depression.

Richard Markgraf, collecting for Eberhard Fraas of Stuttgart, assembled a large collection of vertebrate fossils from the "bone beds" of the lower part of the Jebel Qatrani Formation and was the first fossil collector to explore the upper levels of the formation.

An expedition by Osborn of the American Museum of Natural History and led in the field by Granger made a large collection of fossil vertebrates from quarries in the Jebel Qatrani Formation discovered by Beadnell, Andrews, and Markgraf. Markgraf worked for Granger during this season.

E.L. Simons (then at Yale University) directed the first phase of joint paleontological and geological expeditions to the Fayum with the Geological Survey of Egypt and the Cairo Geological Museum. C.F. Vondra and his students initiated new geological studies, and Simons and his colleagues authored numerous papers describing the Fayum mammals, especially the primates.

Rushdi Said published his "Geology of Egypt," summarizing the most up-to-date knowledge of the geology of the Fayum region and naming the Jebel Qatrani Formation ("Qatrani Formation").

Simons (in Simons and Wood, 1968) summarized paleontologic studies to date in the Fayum region, described the principal fossil quarries, placed them in their approximate stratigraphic context in the upper and lower "fossil wood zones" (upper and lower parts of the Jebel Qatrani Formation as used here), and published faunal lists of vertebrates from the Qasr el Sagha and Jebel Qatrani Formations. K.W. Butzer and C.W. Hansen, in their book "Desert and River in Nubia," again suggested that Oligocene rocks in the Fayum Depression were deposited by an ancestral, north-flowing Nile River.

Vondra (based on work accomplished with the Simons expeditions in 1966 and 1967) described the stratigraphy and paleoenvironments of the upper Eocene Qasr el Sagha Formation, suggesting a deltaic origin for much of the upper part of that unit. B.E. Bowen and Vondra determined that the overlying Oligocene Jebel Qatrani Formation is almost exclusively alluvial in origin, supplanting the nearly 70-year-old use of the term "fluvio-marine beds." Bowen and Vondra named the Widan el Faras Basalt and recognized the unconformity at its base.

R. Salem published a paper on the "Evolution of Eocene-Miocene Sedimentation Patterns in Parts of Northern Egypt" based largely on new subsurface data. Salem identified a narrow structural basin aligned west-southwest-east-northeast and situated between elevated areas in the Fayum region during the late Eocene and Oligocene. Not aware of the work of Bowen and Vondra, he believed Oligocene rocks in the Fayum area to be a combination of prodelta, fan delta, delta front, and marine shale sediments.

Simons (at Duke University) directed the second phase of (ongoing) joint paleontological and geological expeditions to the Fayum with the Geological Survey of Egypt, the Cairo Geological Museum, and the General Petroleum Company. Simons and his colleagues authored numerous papers about the Oligocene mammal fauna of the Jebel Qatrani Formation.

Adriaan Kortlandt published a paper suggesting that geologic and paleontologic evidence of earlier workers shows that the Oligocene paleoenvironment of the Fayum was akin to the sahélien; that is, it was quite dry and had very sparse vegetation. He also believed that the fossil logs of the Jebel Qatrani Formation are allochthonous and were transported as trees hundreds of kilometers northward by an Oligocene "Protonile" river.

Said published "The Geological Evolution of the River Nile," establishing the modern course of the Nile River as a geological feature initiated in the Miocene.

S.L. Wing and B.H. Tiffney published a preliminary study of the fossil leaves, fruits, and seeds of the Jebel Qatrani Formation showing that these forms probably grew in a wet, tropical, probably monsoonal climate. The fruits and seeds show affinities to the fruit and seed flora of the Eocene London Clay and to some modern Indomalaysian fruit and seed floras. T.M. Bown and others published a variety of sedimentologic, paleopedologic, and paleontologic evidence showing that the paleoenvironment of the Jebel Qatrani Formation was a wet, tropical, coastal alluvial plain and that the fossil forests of the Jebel Qatrani are autochthonous and demonstrate that there were major forested areas in the Fayum area during the Oligocene. Sedimentologic studies negate an ancestral Nile River in the Fayum area during the Oligocene. Bown published a study of the ichnofossils and rhizoliths of the Jebel Qatrani Formation, describing rhizoliths of mangroves and larger trees, the first vertebrate burrows from the African Tertiary, and the first trace fossils of subterranean termites.

J.G. Fleagle and others (in press) published a date of 31.0 $\pm 1.0 \mathrm{Ma}$ for the lowest flow of the Widan el Faras Basalt, establishing the age of the Jebel Qatrani Formation fairly conclusively as early Oligocene. 
by the efforts of M. Askalany, Y. Attia, P.J.S. Chatrath, H.H Covert, J.G. Fleagle, D. Gebo, P.D. Gingerich, M. Godinot, G. Gunnell, A. Kandil, J. Kappelman, R.F. Kay, A.A./Latief-Houdab, R. Madden, A. McKenna, B. McKenna, K.C. McKinney, D.T. Rasmussen, E. Rahorimavo, Y. el-Safori, A. Shellaby, B.H. Smith, J.P. Watters, S.L. Wing, and M. Wolfe. We are very grateful to A. Zohdy for the Arabic translation of the abstract and to A. el-Ostaz for its typing. C.F. Vondra generously permitted us to make use of much of his unpublished information on his sections of the Qasr el Sagha and Birket Qarun Formations. Financial support for this research was provided by National Science Foundation grants BNS-80-16206, BNS-81-14925, and BNS-82-09937 and by Smithsonian Foreign Currency grants 70869600 and 809479 to E.L. Simons. Bown's research was assisted in part by a G.K. Gilbert Professional Fellowship with the U.S. Geological Survey.

\section{QASR EL SAGHA FORMATION (UPPER EOGENE)}

\section{INTRODUCTION}

Beadnell (1905) proposed the "Qasr el Sagha series (Carolia beds)" for about $200 \mathrm{~m}$ of crossbedded sand, sandy mud, limestone, and carbonaceous shale that make up the lower of the three principal escarpments bounding the north margin of the Fayum Depression (Qasr el Sagha Escarpment; figs. 1B, 1C). Vondra (in Simons and Wood, 1968) replaced Beadnell's term "series" with "formation" and described this sequence in its type area near the Qasr el Sagha Temple on the northern shore of Birket Qarun, where it is best exposed.

The Qasr el Sagha Formation is distinguished from the conformably underlying upper Eocene Birket Qarun Formation by its greater proportions of sandstone, sandy mudstone, and carbonaceous shale (but see discussion below). From the overlying Jebel Qatrani Formation ("fluvio-marine series" of Beadnell, 1905), the Qasr el Sagha Formation differs in the absence of variegated beds and gravels and in its greater proportion of limestone and shale. Though principally nearshore marine, the Birket Qarun Formation and the Temple Member of the Qasr el Sagha Formation locally contain shoreline deposits and may in part be facies correlatives of about the same age. Detailed studies of the upper $77 \mathrm{~m}$ of the Qasr el Sagha Formation in its type area indicate that this part of the section is both lithologically and paleoenvironmentally quite distinctive. A new name, Dir Abu Lifa Member, is proposed to accommodate these rocks. The name comes from Dir Abu Lifa (see "Glossary"), an ancient Coptic
Christian church about $3 \mathrm{~km}$ above and northeast of the Qasr el Sagha Temple (fig. 1C). The lower $123 \mathrm{~m}$ of the Qasr el Sagha Formation is accorded the name Temple Member for superb exposures in the type area of the formation in the area around the Qasr el Sagha Temple. The temple is a XII(?) Dynasty shrine, possibly to the ancient Egyptian crocodile god Sobek.

\section{DISTRIBUTION}

Though best developed in its type area (figs. $1 C, 3$ ), the Temple Member of the Qasr el Sagha Formation is well exposed to the west along the lower north escarpment of the Fayum Depression to Wadi Kadish (fig. $1 B$ ), where the escarpment turns southward, and in the area west of Garet Gehannam and to the south as far as Garet Maghnini (fig. 1B). South of Garet Maghnini, the lower escarpment merges gradually with the desert serir; however, rocks of the Temple Member have been mapped from poor exposures developed entirely around the Fayum Depression (Said, 1962). To the east of the type area, southeast of Widan el Faras (figs. $1 C, 2 F$ ), the Temple Member thins to about half its normal thickness $3 \mathrm{~km}$ north of Wadi Ghorab (fig. $2 F$ ), and exposures are again subdued until the area north of Wadi el Raml (fig. $2 F$ ), where the lower escarpment is again developed adjacent to the Nile Valley. The Temple Member, or a close lithological correlative, is also present beneath some of the extensive serir separating the Fayum Depression and the Bahariya Oasis (fig. $1 A$ ), in the upper part of the eastern escarpment of the Bahariya Oasis, and in and around the Qattara Depression (Geological Survey of Egypt, 1981; G. Franks, oral commun., 1981).

In the region about $15 \mathrm{~km}$ west of Garet Gehannam and on the northwest shore of Birket Qarun, it seems likely that the Temple Member of the Qasr el Sagha Formation is actually a facies correlative of at least part of the supposedly older Birket Qarun Formation.

The Dir Abu Lifa Member of the Qasr el Sagha Formation is also relatively unrestricted in its areal distribution; it thickens considerably west of the Alexandria Trail (on the west; figs. $2 B, 2 C$ ) and thins markedly east of the basalt mine (on the east). It is best exposed in the castellate exposures in the region around Garet el Esh, the Qasr el Sagha Temple, and Dir Abu Lifa (fig. 4). The Birket Qarun and Qasr el Sagha Formations are believed to be facies correlatives of the Operculina bed of the Mokattam Formation and the Upper Mokattam (Ma'adi) Formation, respectively, of the Nile Valley near Cairo (Said, 1962).

\section{TEMPLE MEMBER}

The Temple Member includes the lower $123 \mathrm{~m}$ of the Qasr el Sagha Formation and consists primarily of thin 


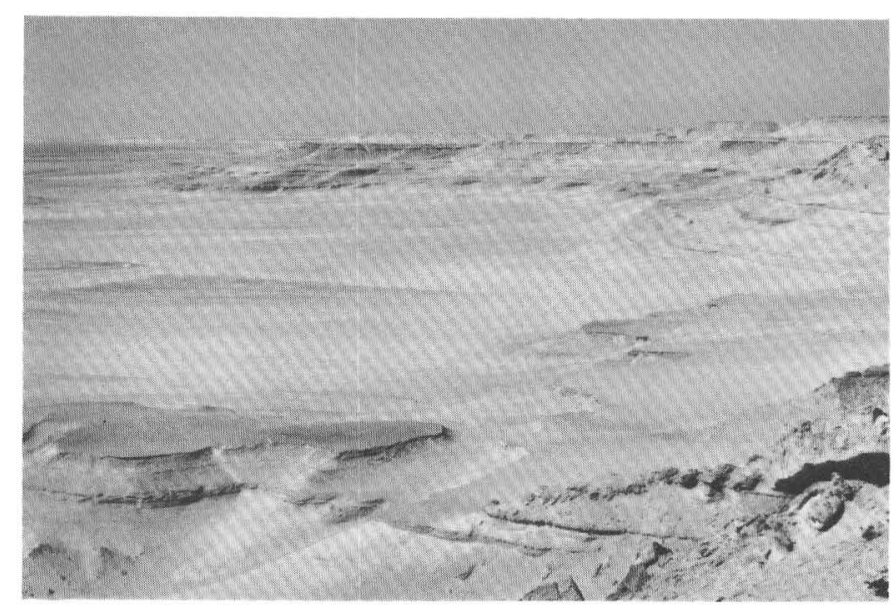

Figure 4.-Cliffs and benches developed on the Temple Member and (above top of bench in far distance) the lower part of the Dir Abu Lifa Member, Qasr el Sagha Formation. View is to west-southwest. Top of bench in far distance is about $65 \mathrm{~m}$ above valley floor.

glauconitic to limonitic arenaceous limestones and fine quartz sandstones that are interbedded with thicker, generally laminated sandy mudstones and carbonaceous mudstones. As observed by Vondra (1974), gypsum is abundant in this part of the formation where it is distributed throughout the sediments as finely disseminated fibrous crystals, as platy masses developed along fractures and bedding planes, and as " "***wedges that fill polygonally disposed subvertical to vertical shrinkage cracks" (Vondra, 1974, p. 85). Leaf remains are common in the carbonaceous units, and numerous mollusks occur in the sandy limestones and, less commonly, in the quartz sandstones and sandy mudstones. The molluskan faunas were described in Beadnell (1905) and by E.G. Kauffman (in Vondra, 1974), and the fossil leaf flora from a few localities in the Temple Member is currently under study (S.L. Wing, written commun., 1983). The trace fossil Ophiomorpha is common in some of the sandy mudstones.

Temple Member lithologies are laterally quite persistent and individual beds a few tens of centimeters thick are sometimes traceable for several kilometers. The sandy limestones and sandstones form numerous somber gray, green, and brown ledges all along the lower part of the Qasr el Sagha Escarpment, where they are separated by more gentle slopes developed on the finer grained clastic units.

Beadnell (1905) and Vondra (1974) have adequately described the rocks, faunas, and paleoenvironments of the Temple Member of the Qasr el Sagha Formation. A brief summary of Vondra's observations is relevant here to place the Temple Member in its sedimentary and paleoenvironmental context relative to the Dir Abu Lifa Member. Vondra (1974) placed all of the rocks here included in the Temple Member in his "arenaceous bioclastic carbonate facies" and his superjacent "gypsiferous and carbonaceous laminated claystone and siltstone facies," observing that these two facies packages intertongue considerably throughout their area of distribution. On the basis of studies of the sediments and mollusks, Vondra concluded that the lower part of the Temple Member (the "arenaceous bioclastic carbonate facies") was deposited in marine bar front to estuarine mouth environments characterized by “****water depths generally less than $20 \mathrm{~m}$ " (Vondra, 1974, p. 85). In contrast, the upper part of the Temple Member (Vondra's "gypsiferous and carbonaceous laminated claystone and siltstone facies") appears to have been deposited in shallow lagoons, possibly on the “***lee side of barrier islands" (Vondra, 1974, p. 86).

This interpretation agrees well with conclusions we have reached regarding the paleoenvironment of the Temple Member south and east of Dir Abu Lifa. In that area, the middle third of the Temple Member yields abundant cetacean (whale) remains associated with limonitized fossil logs, the bones of sea snakes, crocodiles, turtles, and fish, countless vertebrate coprolites, and waterworn mollusk shells. These fossils occur in four thin calcareous quartz sandstones and sandy mudstones. The association of large numbers of fossils of marine mammals with both terrestrial and marine reptiles, fish, coprolites, and reworked mollusks is suggestive of strandline deposits that accumulated as swash lags on beaches or as intertidal lags that formed somewhat offshore. The extreme lateral persistence of these deposits, often several kilometers in lateral extent, combined with the more or less east-west parallel alignment of most of the fossil logs, is also indicative of nearshore accumulation, probably under the influence of essentially unidirectional currents. Whether the fossil concentrations accumulated in an estuarine environment, in a shallow lagoon, or on the lee side of barrier islands cannot yet be determined; however, it is clear that water depths were almost certainly in places less than $20 \mathrm{~m}$. Several similar fossil lag deposits containing higher proportions of the remains of land vertebrates are developed in the overlying Dir Abu Lifa Member, a unit that appears to be estuarine and lagoonal as well as alluvial in origin.

\section{DIR ABU LIFA MEMBER}

The upper $77 \mathrm{~m}$ of the Qasr el Sagha Formation is here referred to the Dir Abu Lifa Member (new name). These rocks were examined by us in the area between Dir Abu Lifa and Garet el Esh (fig. 1C) during the 1981 and 1983 field seasons, between Dir Abu Lifa and Elwaht Hialla during the 1984 season, and in the areas of Wadi Kadish and west of Garet Gehannam in the 1985 season. The type section of the Dir Abu Lifa Member (fig. 5) reveals the presence of eight principal units that can be correlated over most of the type area. 

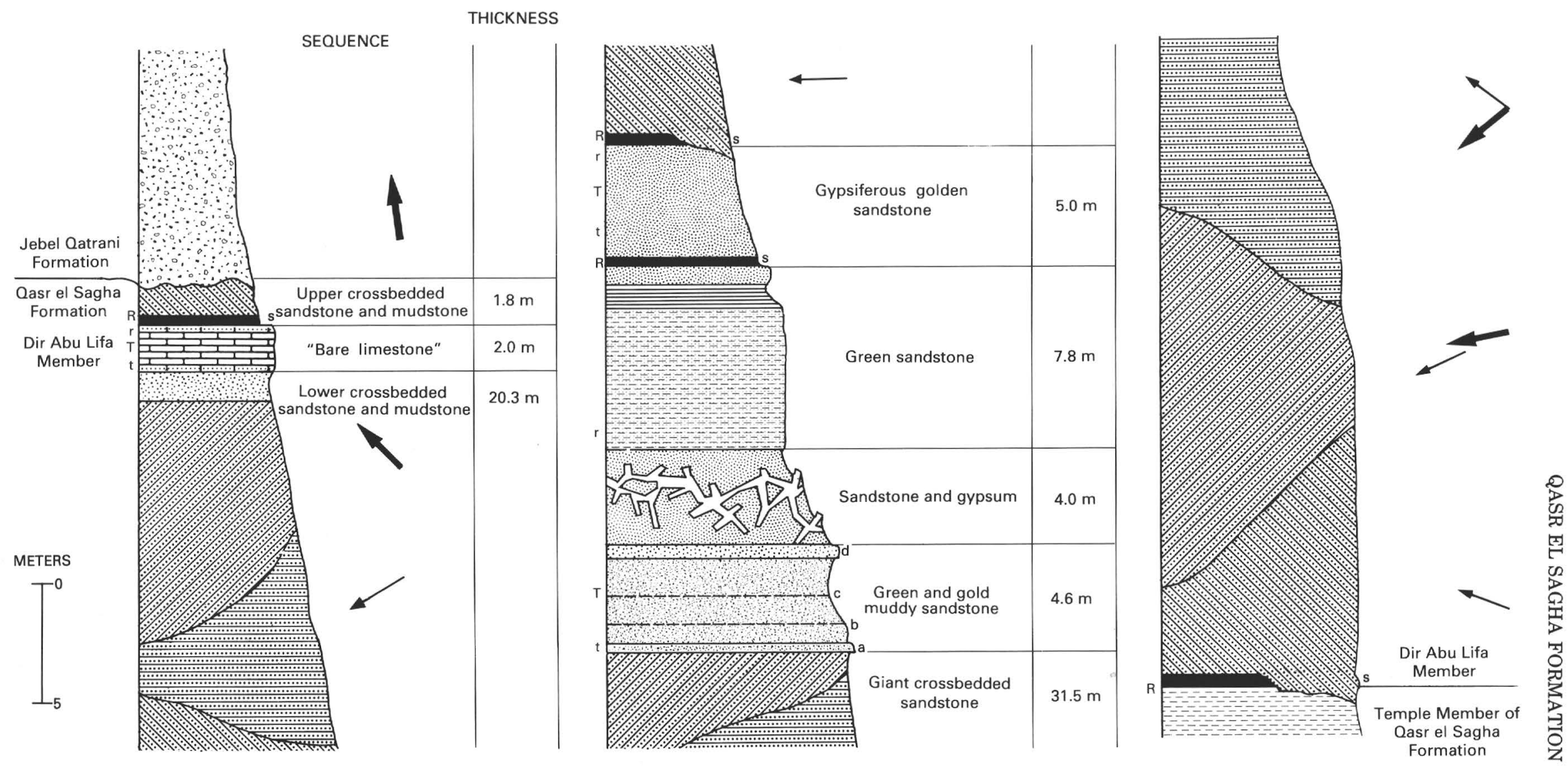

\section{EXPLANATION}

$\therefore$ Sandstone; coarse to medium; gravelly

. Sandstone; coarse to medium; little or no gravel

... Sandstone; medium to fine

W. Sandstone; gypsiferous

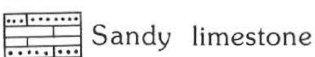

Gypsum dikes

W. W $_{\text {K }}$ Sandstone; medium to fine; epsilon cross stratification

$=$ Mudstone; sandy

Mudstone

Limestone

Shale

Letters a-d and other letters $(R, r, T, t)$ refer to specific units and transgressive and regressive phases, respectively, that are discussed in text. $\mathrm{S}$ denotes strandline accumulations of conglomeratic coquina rich in fossil vertebrate remains.

IGURE 5.-Stratigraphic column showing lithologies of the type section of the Dir Ab west of Dir Abu Lifa. Large arrows show paleocurrent directions on large-scale stratification, and small arrows, on small-scale stratification, for columns on left. 


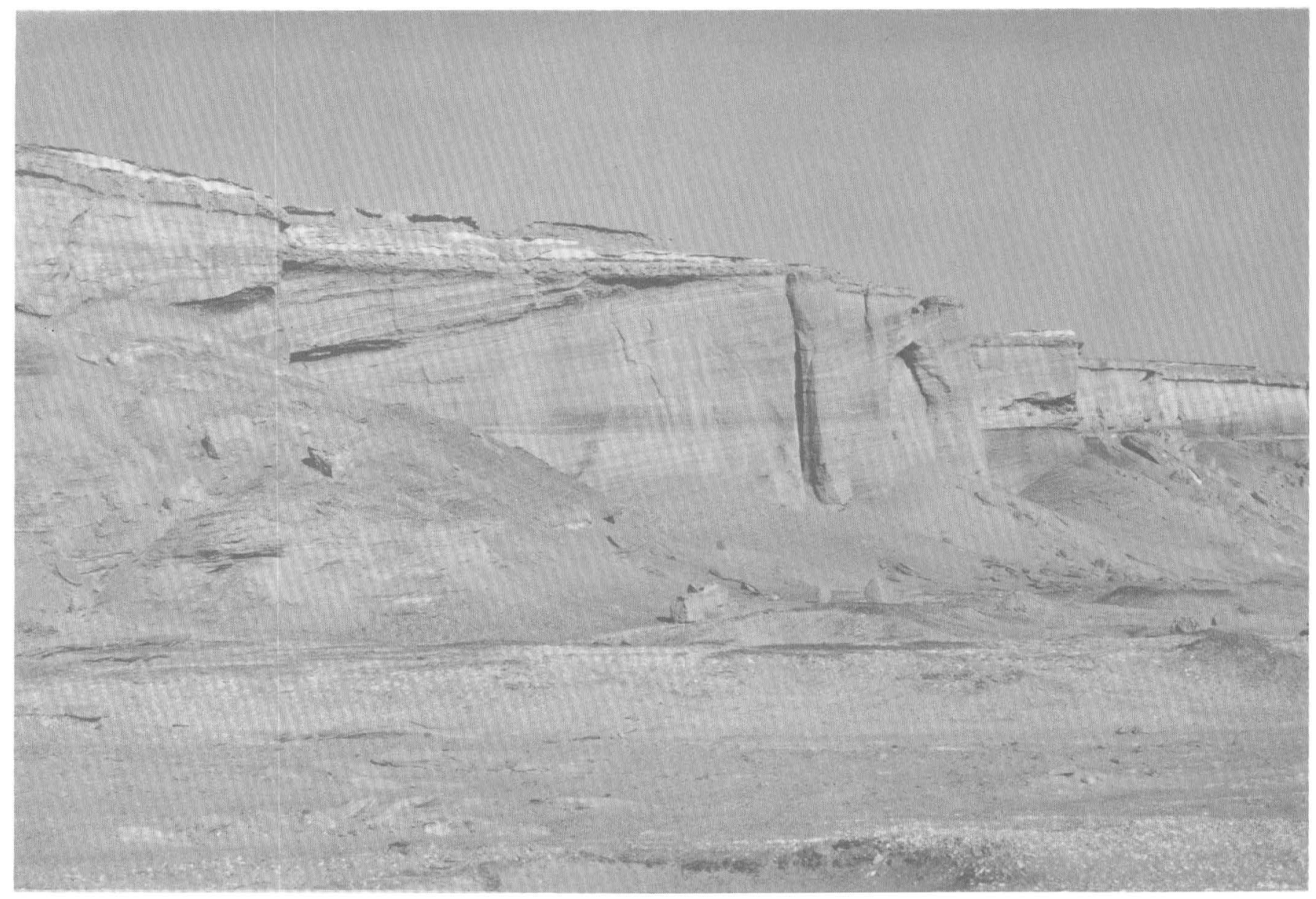

FiguRE 6.-North-dipping large-scale lateral accretion deposits within giant crossbedded sandstone sequence of the lower part of the Dir Abu Lifa Member of the Qasr el Sagha Formation, as exposed about $0.5 \mathrm{~km}$ northwest of the Qasr el Sagha Temple,
Fayum Province, Egypt. Deposits lie in two superposed channels. Flat-laying rocks on the horizon belong to the green and gold muddy sandstone sequence of the Dir Abu Lifa Member. Cliff is approximately $31 \mathrm{~m}$ high.

\section{GIANT CROSSBEDDED SANDSTONE SEQUENCE}

This unit is topographically and sedimentologically the most distinctive in the Qasr el Sagha Formation and is characteristically developed as vertical cliffs in and surrounding the type area above Qasr el Sagha Temple (figs. 6, 8). It was termed the "interbedded claystone, siltstone, and quartz sandstone facies" by Vondra (1974, p. 86) and consists mainly of unusually thick sets of cross-stratified white sandstone (foresets) that contain smaller intrasets of alternating crossbedded sandstone and carbonaceous mudstone. Because the large cross sets greatly exceed $3 \mathrm{~m}$ in thickness, they are giant in scale (McCabe, 1977). The giant cross sets lie above erosion surfaces that appear to be channel scours varying in breadth from 40 to $750 \mathrm{~m}$ and in depth from 3 to $25 \mathrm{~m}$ (figs. 6,7 ). Therefore, the entire giant crossbedded sandstone sequence consists of several superposed channel deposits.

The giant foresets show intrasets of large- and medium-scale trough and tabular cross stratification with sets $20-80 \mathrm{~cm}$ thick, and of ripples up to $12 \mathrm{~m}$ thick. Clay drapes are abundant and rhizoliths are common locally. In places, small-scale cross-stratified sets rest above the large-scale sets. The giant foresets $\operatorname{dip} 3^{\circ}-12^{\circ}$ in directions that are approximately transverse to current orientations determined from ripples $\left(305^{\circ}\right)$ and large-scale intrasets $\left(285^{\circ}\right.$ and $\left.294^{\circ}\right)$. The direction of dip of the giant foresets (north to northwest, according to Vondra, 1974) actually varies from $355^{\circ}$ at Qasr el Sagha to $185^{\circ}$ at Garet el Esh (fig. 8), and $229^{\circ}$ and $345^{\circ}$ at Dir Abu Lifa, and $236^{\circ}$ at a locality $4 \mathrm{~km}$ west of the Alexandria Trail. The alignment of the channels that contain the giant crossbed sets is therefore essentially west or west-northwest, and ap- 


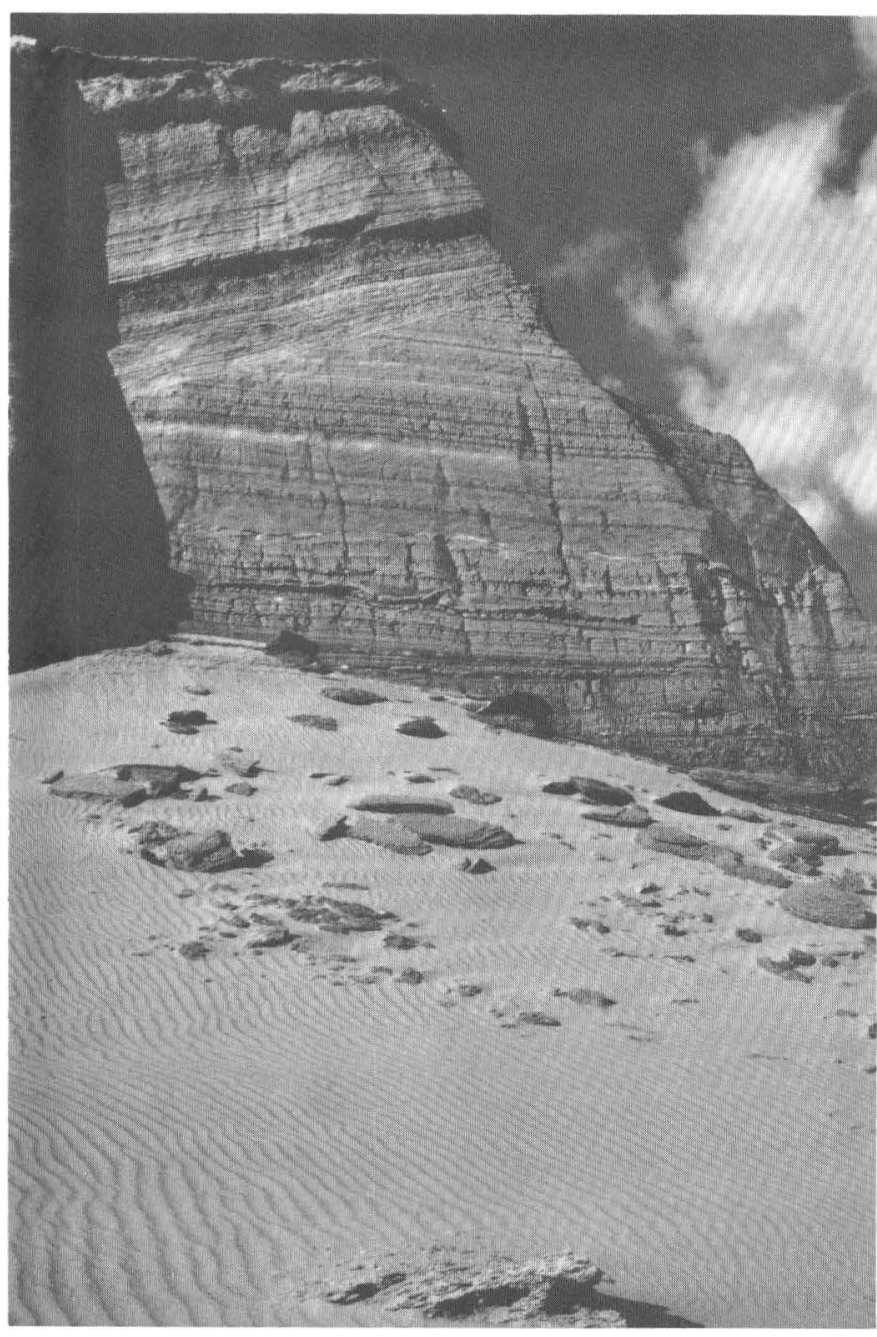

FiguRE 7.-Giant crossbedded sandstone sequence of the Dir Abu Lifa Member of the Qasr el Sagha Formation, as exposed about $1 \mathrm{~km}$ northeast of the Qasr el Sagha Temple, with a channel scour truncating the lower part of the sequence (about halfway up the cliff). Cliff top is about $25 \mathrm{~m}$ above head of dune.

proximately parallel to current orientations obtained from ripples and large-scale intrasets.

The giant crossbedded sandstone sequence is channeled into the underlying Temple Member of the Qasr el Sagha Formation and intertongues with the overlying green and gold muddy sandstone sequence. The sequence thickens markedly west of Garet el Esh and thins northeast of Dir Abu Lifa and is absent along the low escarpment between the basalt mine (fig. $1 B$ ) and Elwaht Hialla. It is well developed and thick far to the west beyond the Alexandria Trail, 10-15 km west of Garet Gehannam, and at Madwar el Bighal. North and northeast of Dir Abu Lifa, it is replaced by a similar sequence but one without the giant foresets.

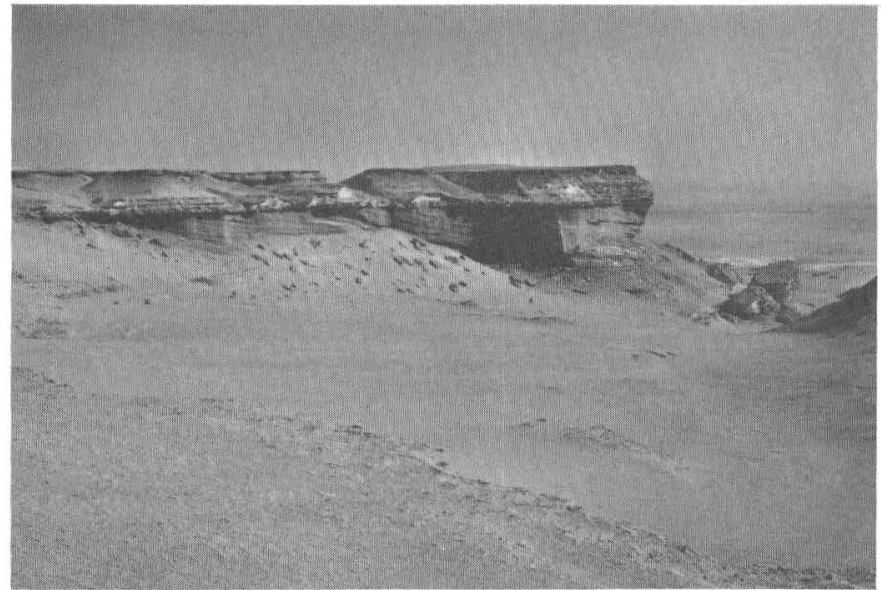

FigURE 8.-South-dipping lateral accretion deposits within giant crossbedded sandstone sequence in the lower part of the Dir Abu Lifa Member of the Qasr el Sagha Formation, as exposed $2.5 \mathrm{~km}$ east of Garet el Esh. Overlying rocks include the green and gold muddy sandstone sequence, the sandstone and gypsum sequence, and the green sandstone sequence of the Dir Abu Lifa Member of the Qasr el Sagha Formation. Cliff in right middle distance is approximately $35 \mathrm{~m}$ high.

As observed by Vondra (1974), fossils are rare in this unit; however, Carolia valves, crab claws, shark teeth, and plant fragments are found locally, and many of the sands contain structureless vertical and inclined burrows a few centimeters long and horizontally disposed sinuous, anastomosed burrows up to $0.8 \mathrm{~m}$ in length and $5 \mathrm{~cm}$ in breadth. The base of the giant crossbedded sandstone sequence and the bases of some of the channels contained in this sequence are marked locally by thin coquinas of marine shell fragments and vertebrate remains. These include Carolia and Ostrea fragments, crab claws, shark, skate, and ray teeth, Pterosphenus (sea snake) vertebrae, and rare turtle, crocodile, and mammal bones. Bones and teeth of the mammals Brachyodus, Moeritherium, Barytherium, Apterodon, Eotheroides, and, possibly, Arsinoitherium are associated with the latter remains in a similar coquina developed locally near the top of the sequence. A partial skeleton of Moeritherium was discovered about $12 \mathrm{~m}$ above the base of the sequence in 1984 .

GREEN AND GOLD

MUDDY SANDSTONE SEQUENCE

This sequence is thin in the area around Qasr el Sagha Temple but thickens to its maximum of about $6 \mathrm{~m}$ near Dir Abu Lifa and between Qasr el Sagha and Garet el Esh. Because the base of the sequence is gradational with underlying rocks or has a mildly erosional relationship to them, it is thin or absent where the giant crossbedded sandstone sequence is thickest. 
Where the green and gold muddy sandstone sequence is best developed, it is expressed topographically as one or more low benches. This and the six succeeding sequences were included by Vondra (1974) in his "quartz sandstone facies."

Above Qasr el Sagha Temple, this sequence consists from bottom to top of (1) a basal golden sandstone containing abraded mollusk shells, (2) a calcareous green shale capped by a thin calcareous sandstone containing numerous single valves of the oyster Carolia placunoides, (3) a calcareous green shale capped by another thin calcareous sandstone containing numerous single valves of an oyster resembling Exogyra (D. Wilson, oral commun., 1985), and (4) another calcareous green shale with a sandy zone near the top and with a coquina of rounded fragments of shells of several kinds of mollusks. (Fossil-bearing units are a-d to right of middle column, fig. 4).

In other areas, the green and gold muddy sandstone sequence consists of interbedded green and gold medium sandstone that becomes muddier upwards. Internal stratification is poor owing to disruption by growth of satin spar veinlets and by abundant anastomosed burrows, including Ophiomorpha and burrows of crabs. Where cross stratification is discernible, it is large-scale trough or tabular. Iron oxyhydrate nodules (including high-grade yellow, brown, and red ochre) are common in 10-45-cm bands, where they are associated with pervasive mottling.

The green and gold muddy sandstone sequence or a lateral variant forms much of the upper part of the Dir Abu Lifa Member in the western part of the Fayum Depression (at Madwar el Bighal and Wadi Kadish).

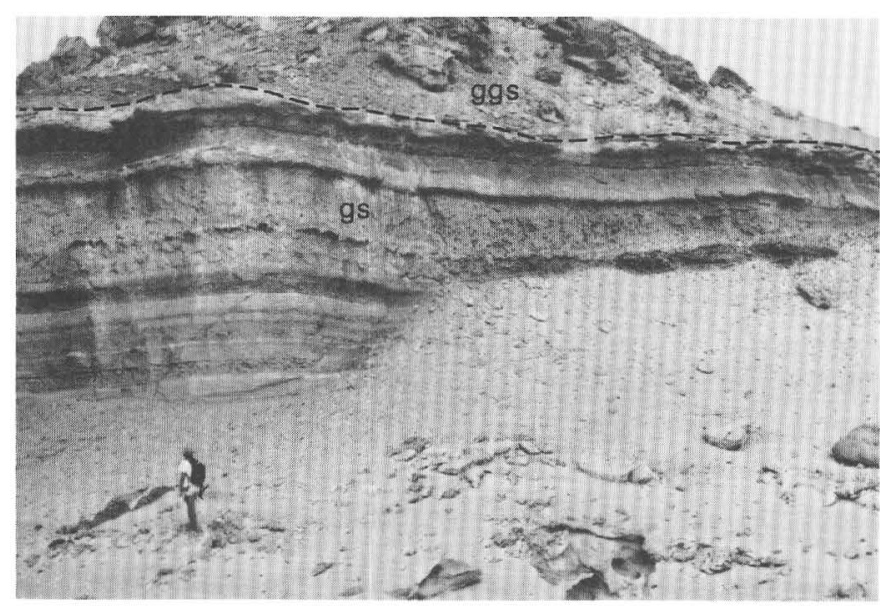

FiguRE 9.-Green sandstone (gs) and gypsiferous golden sandstone (ggs) sequences of the Dir Abu Lifa Member of the Qasr el Sagha Formation, as exposed in Wadi Ghorab, about $0.5 \mathrm{~km}$ north of Dir Abu Lifa. Dashed line indicates contact. Rugose areas in middle of green sandstone sequence are innumerable sinuous horizontal burrows cemented with iron oxyhydrate minerals.
SANDSTONE AND GYPSUM SEQUENCE

A layer of $4 \mathrm{~m}$ of green shaly mudstone containing massive sandy gypsum and barite nodules (up to $30 \mathrm{~cm}$ in diameter) at the base overlies the green and gold muddy sandstone sequence at Qasr el Sagha and is present sporadically at the same level as far as $1 \mathrm{~km}$ west of Garet el Esh and $8.5 \mathrm{~km}$ northeast of Dir Abu Lifa. Gypsum is abundant throughout the unit and that in the middle of the sequence is developed as polygonal satin spar dikes with polygons up to $4.5 \mathrm{~m}$ in diameter. Nodules of barite are commonly associated with the gypsum and locally make up about 10 percent of the unit. The gypsum is similar to that described by Vondra (1974, p. 85, and his fig. 4) from the Temple Member, and the presence of lunate worked flints and partially fashioned gypsum bowls scattered on the surface of the bed show that it was a source of industrial gypsum in pre-Dynastic Egypt (Caton-Thompson and Gardner, 1934).

\section{GREEN SANDSTONE SEQUENCE}

This unit (figs. 5, 9) consists of $7.8 \mathrm{~m}$ of fine-medium green muddy sandstone with prominent gold mottles and no preserved internal stratification. It is well exposed above the sandstone and gypsum sequence throughout the Dir Abu Lifa-Garet el Esh area, though it is locally more gold than green in color (Dir Abu Lifa) or is reddish in the upper part (Garet el Esh). It is typified by innumerable golden brown to red anastomosed burrows and nodules of barite, siderite, and iron oxyhydrates. The burrows include poorly preserved vertical and inclined unstructured forms, sinu-

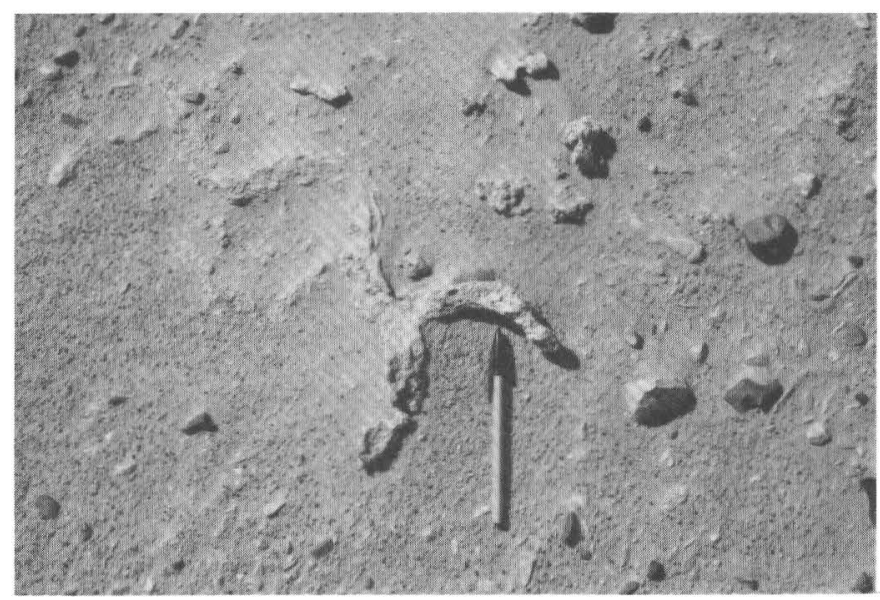

Figure 10.- Sinuous, branched, horizontal crab burrows exposed on the surface of the green sandstone sequence of the Dir Abu Lifa Member of the Qasr el Sagha Formation. 
ous horizontally disposed branched crab burrows (fig. 10), and Ophiomorpha. About $2 \mathrm{~m}$ below the top of the sequence is a green shale with abundant plates of selenite and satin spar gypsum. The upper meter is a gypsiferous golden sand which has an upper surface covered by a veneer of platy dark brown ironstone and siliceous ironstone fragments. Though the fragments seem to originate from this level, none were found in place. Scattered among the ironstone fragments are pieces of poorly preserved fossil wood (sometimes containing vertical borings $=$ Teredolites, fig. $11 \mathrm{~A}$; see Kelly and Bromley, 1984), and in one instance bearing
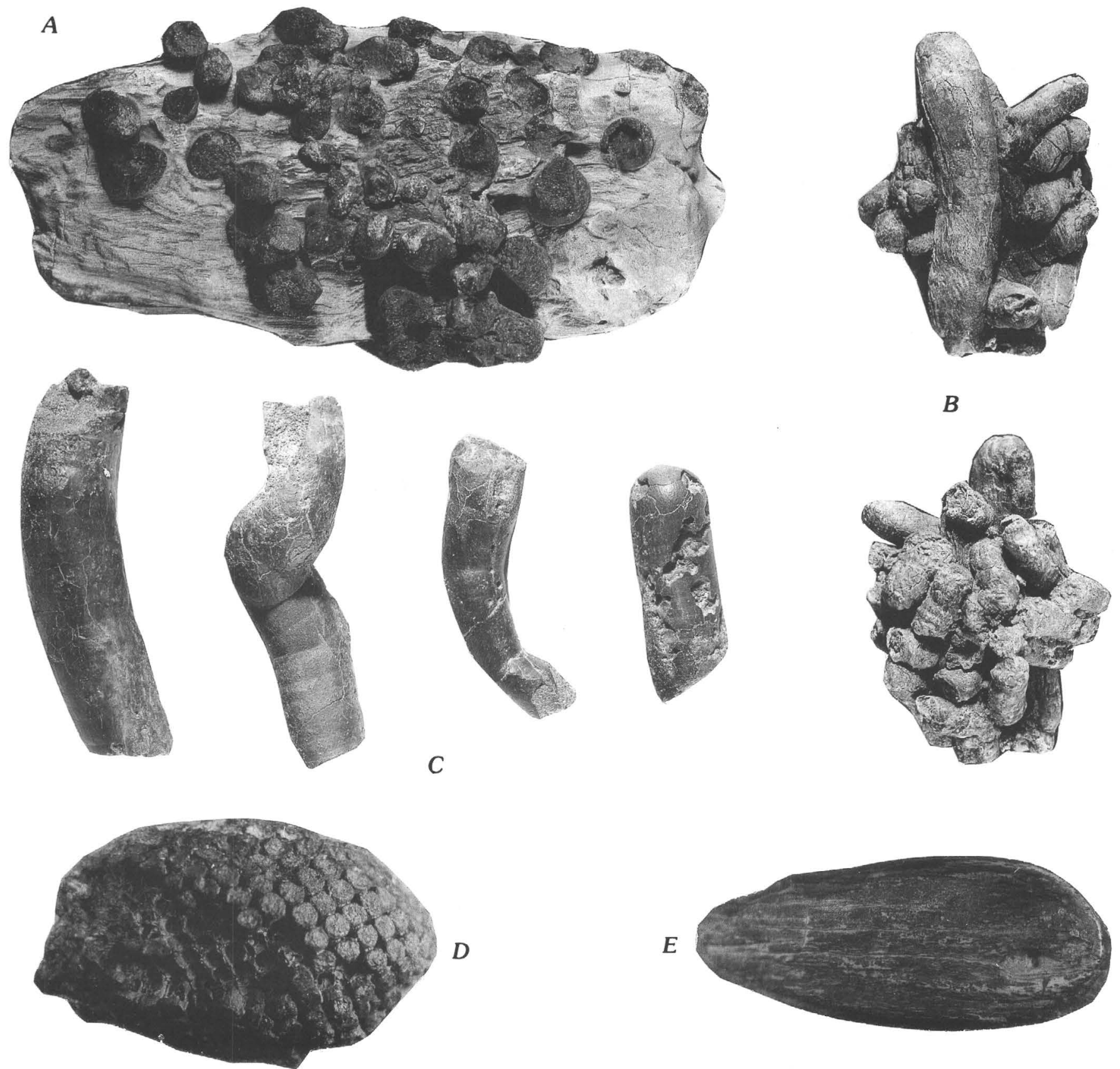

Figure 11.-Trace fossils from the Dir Abu Lifa Member of the Qasr el Sagha Formation $(A-C)$ and fossil fruit and wood from the Jebel Qatrani Formation $(D, E)$. A, B, Teredolites clavatus and Teredolites sp., USGS 10517 and 10518, respectively. $C$, Teredolites sp., USGS 10519. D, Iron-silicate petrifaction of compound infructescence of the liane Epipremnum. $E$, Water-abraded silicified wood. 
a colony of complete (unidentified) pelecypods in growth position.

\section{GYPSIFEROUS GOLDEN SANDSTONE SEQUENGE}

The base of the gypsiferous golden sandstone sequence is conglomeratic coquina about $10-15 \mathrm{~cm}$ thick of hollow, broken, reddish-brown iron oxyhydrate nodules, vertebrate coprolites, fish vertebrae and spines, shark teeth, skate and ray mouthparts, catfish remains, sea snake vertebrae, sirenian bones, gypsum and ironstone steinkerns of coprolites and several kinds of gastropods and bivalves, and gypsiferous limonitized wood. Much of the fossil wood contains borings (fig. 11A). This unit persists lateral to the line of section for at least $8 \mathrm{~km}$ and is quite similar in appearance and composition to those at the bases of the giant crossbedded sandstone sequence and the lower and upper crossbedded sandstone and mudstone sequences. The conglomeratic coquina is succeeded by about $4 \mathrm{~m}$ of green and gold silty sandstone that is permeated with red, yellow, and brown sinuous crab burrows and plates and veinlets of selenite. Red mottling is developed locally in this part of the unit and single valves of Carolia placunoides are encountered immediately above the basal conglomeratic coquina. The top of this sequence is a resistant medium-fine massive golden sandstone about a meter thick and containing impressions of shells, broken, waterworn gastropods, and valves of bivalves. The gypsiferous golden sandstone sequence is practically devoid of cross stratification or laminae, the numerous crab burrows (see Hayasaka, 1935) suggesting these have been obliterated by bioturbation.

\section{LOWER CROSSBEDDED SANDSTONE AND MUDSTONE SEQUENCE}

Like the gypsiferous golden sand sequence, the base of this unit is made up of a thin, tabular, conglomeratic coquina. This conglomerate varies in thickness from 0.1 to $0.5 \mathrm{~m}$ and persists laterally more than $60 \mathrm{~km}$ between the area west of Garet Gehannam, eastward to at least the vicinity of Wadi Ghorab (fig. $1 C$ ). In the Garet el Esh-Qasr el Sagha-Dir Abu Lifa area (fig. $1 C$ ), the conglomerate consists of broken, hollow, sometimes water worn iron oxyhydrate nodules (sometimes containing coprolites), vertebrate coprolites, shark teeth, skate and ray mouthparts, fish bones of all kinds, reptile and mammal bones and teeth, and both limonitized and silicified fossil wood. The fossil remains are overwhelmingly dominated by coprolites and shark and ray teeth, but bones of sawfish, catfish, sea snakes (Pterosphenus), crocodiles, turtles, whales, sirenians, Moeritherium, and iron-silicate petrifactions of compound water lily fruits (S.L. Wing, oral commun., 1984) occur. Also abundant locally are fragments of waterworn silicified wood (some specimens are pervasively burrowed, cf. Teredolites; fig. $10 C$ ). The ironstone nodules, coprolites, and body fossils are held together in a friable to moderately well cemented matrix of finemedium limonitic sand containing some crystalline gypsum. Though generally present, fossils are not everywhere abundant, and in many places this unit is marked only as a zone of transported waterworn ironstone nodules and coprolites (for example, about $3 \mathrm{~km}$ northeast of Wadi Ghorab, fig. $2 E$ ). Some $10 \mathrm{~km}$ north of Wadi Ghorab this unit is marked by a conspicuous zone of rhizoliths in growth position.

In the type area of the Dir Abu Lifa Member, the conglomeratic coquina lies in a trough that is shallowly $(5.8 \mathrm{~m})$ excavated into underlying rocks. One kilometer north of Dir Abu Lifa at Wadi Ghorab (fig. 12), this trough has a bearing of $9^{\circ}$, and the base of the trough there is made up of about $1 \mathrm{~m}$ of ironstone nodules. The topographically highest margins of the basal trough deposit in this area yield numerous cross sections of stumps of small trees replaced by gypsiferous sand (analogs from older rocks were described by Kraus, 1985).

Above the conglomeratic coquina, the lower crossbedded sandstone and mudstone sequence is made up of about $20 \mathrm{~m}$ of gently inclined, giant sets of crossbedded white or gold fine- to medium-grained sandstone and pale green or gold sandy mudstone (fig. 13). Sets are developed above scours, which range in depth from 3 to $5 \mathrm{~m}$ and which generally lack a coarse basal lag. In general, scour fills at the top of the sequence contain finer sediment than do scour fills at the bottom. Giant sandstone foresets consist internally of large- and small-scale cross stratification, whereas sandy mudstone foresets consist internally of small-scale cross stratification and horizontal stratification. Small- and large-scale cross stratification yield paleocurrent bearings ranging from $260^{\circ}$ to $320^{\circ}$. Rhizoliths and small vertical cylindrical burrows commonly occur immediately beneath set boundaries and more rarely occur elsewhere.

This unit thins to about $8 \mathrm{~m}$ some $3 \mathrm{~km}$ east of Wadi Ghorab and is about $15 \mathrm{~m}$ thick some $10 \mathrm{~km}$ farther north. It is absent at Elwaht Hialla. The lower crossbedded sandstone and mudstone sequence is distinctive near the top of the Dir Abu Lifa Member and is readily identified throughout the Wadi Kadish-Dir Abu Lifa area by alternation of white and green crossbedded units and the several large and obvious scour surfaces (figs. 12, 13).

In the type area of the Dir Abu Lifa Member, the top of the lower crossbedded sandstone and mudstone sequence is a gold sandstone, consisting of medium- to 


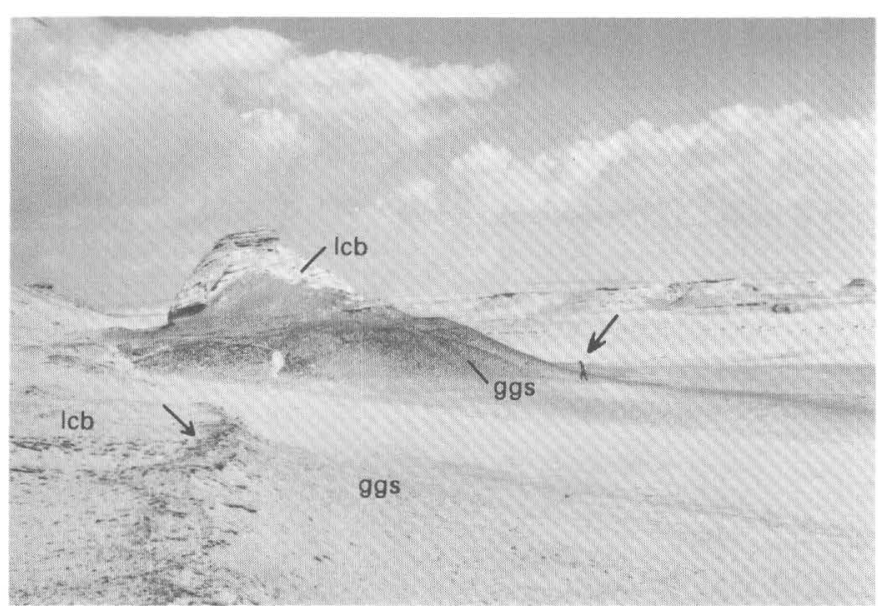

FIGURE 12.-Gypsiferous golden sandstone sequence (ggs) overlain by lower crossbedded sandstone and mudstone sequence (Icb) of the Dir Abu Lifa Member of the Qasr el Sagha Formation, in Wadi Ghorab about $4.0 \mathrm{~km}$ north of Dir Abu Lifa. Note conglomeratic coquina (arrow in foreground and very dark platy unit one-third of way up hill in distance) at base of lower crossbedded sandstone and mudstone sequence. In this area, the conglomeratic coquina is developed at the base of a trough-shaped scour that is aligned essentially east-northeast-west-southwest. Man (at arrow) gives scale.

coarse-grained gold and greenish-gold sand that is cemented with calcium carbonate and is resistant and ledge-forming. Internal stratification has largely been obscured by burrowing but where determinable it appears to be horizontal. Termitaria (Termitichnus; Bown, 1982) occur in the top of.this sandstone, as do poorly preserved sinuous, cylindrical burrows. Waterworn silicified wood, vertebrate bone, and fragments of marine mollusks occur locally.

"BARE LIMESTONE" SEQUENCE

North of Qasr el Sagha Temple, the lower crossbedded sandstone and mudstone sequence is overlain by a laterally persistent, unsorted, fine to course sandstone with lateral equivalents of arenaceous biomicrosparudite (Bowen and Vondra, 1974, p. 118). This sequence contains occasional shark and ray teeth, fragments of bone and silicified wood, and late Eocene marine mollusks. Most of these fossils appear to be abraded, and fossil ants' nests and Termitichnus occur locally. Called the "bare limestone" by Beadnell (1905), this sequence (fig. 14) derives its name from its upper surface, which is exposed over a wide area at the top of the Qasr el Sagha Escarpment; its distinctive gray color appears shiny and bare when viewed from a distance owing to sand polishing by the wind. The "bare limestone" sequence extends from the Madwar el Bighal area west of Garet Gehannam (fig. $1 B$ ) for an unknown distance east of Dir Abu Lifa. It is well developed at the top of the Qasr el Sagha Escarpment north

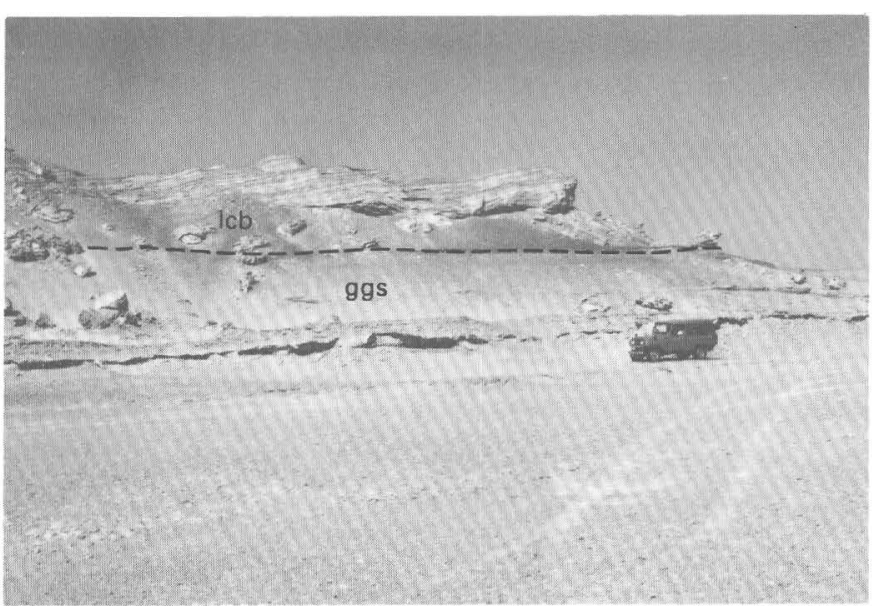

Figure 13.-Exposures of gypsiferous golden sandstone sequence (ggs) and lower crossbedded sandstone and mudstone sequence (Icb) of the upper part of the Dir Abu Lifa Member of the Qasr el Sagha Formation, as exposed about $1.5 \mathrm{~km}$ west of the Qasr el Sagha Temple. Dashed line indicates contact. Note large-scale lateral accretion deposits in lower crossbedded sandstone and mudstone sequence.

of Garet Umm el Zalat at the west edge of Birket Qarun (fig. $1 B$ ) and is very thick (exceeding $10 \mathrm{~m}$ ) near Madwar el Bighal at the far western extremity of the Fayum Depression. On the east, the "bare limestone" sequence is present at least $6 \mathrm{~km}$ east of the basalt mine and may persist all the way to Elwaht Hialla. In the area around the Qasr el Sagha Temple, the contact of the "bare limestone" sequence with the underlying lower crossbedded sandstone and mudstone sequence

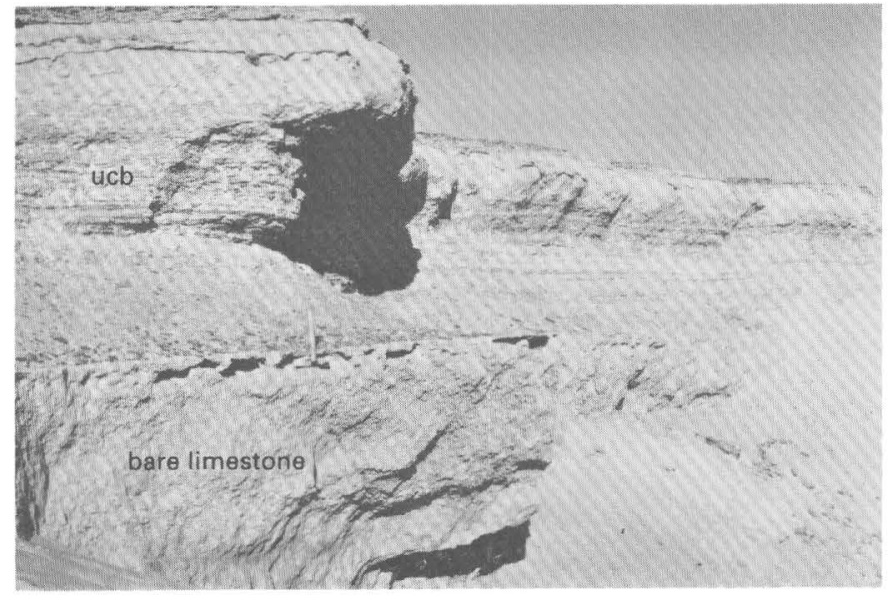

FIGURE 14.- "Bare limestone" and upper crossbedded sandstone and mudstone sequence (ucb) of the upper Dir Abu Lifa Member of the Qasr el Sagha Formation at the head of Wadi Efreet, about $2.5 \mathrm{~km}$ north-northeast of the Qasr el Sagha Temple. Hammer denotes contact. 
appears to be gradational, whereas its upper contact varies from gradational to shallowly erosional. In no place, however, does the Qasr el Sagha FormationJebel Qatrani Formation contact appear to represent a major unconformity. The "bare limestone" sequence has traditionally marked not only the Qasr el Sagha Formation-Jebel Qatrani Formation contact (Vondra, 1974; Bowen and Vondra, 1974), but also the EoceneOligocene boundary in northern Egypt (Said, 1962). Its stratigraphic significance has been modified somewhat by discovery of the following unit.

\section{UPPER CROSSBEDDED SANDSTONE AND MUDSTONE SEQUENCE}

The Jebel Qatrani Formation was once thought to lie conformably (Said, 1962) or paraconformably (Bowen and Vondra, 1974) on the Qasr el Sagha Formation. In 1984, examination of exposures in Wadi Efreet (fig. $1 C$ ), at the point where the wadi begins to cut through the top of the Qasr el Sagha Escarpment, revealed about $8 \mathrm{~m}$ of rocks lithologically resembling those of the lower crossbedded sandstone and mudstone sequence and lying atop the "bare limestone" sequence (fig. 14). These rocks consist of (1) a basal 10-12-cmthick conglomeratic coquina (similar to others described from the Dir Abu Lifa Member) and (2) about $8 \mathrm{~m}$ of medium-scale trough and ripple cross-stratified quartz sandstone containing abundant mud drapes and rhizoliths. The top of this sequence is truncated by an erosion surface that in places descends more than $9 \mathrm{~m}$, penetrating the "bare limestone" sequence. The entire exposure of the upper crossbedded sandstone and mudstone sequence, as far as is known, is confined to the Wadi Efreet area. Elsewhere, it has been removed by erosion or is buried beneath float debris from the overlying unconsolidated lower gravelly sandstone sequence of the Jebel Qatrani Formation. This unit is important only in that it demonstrates that the Qasr el Sagha Formation-Jebel Qatrani Formation contact (and possibly also the Eocene-Oligocene boundary) is at least locally marked by a minor erosional unconformity.

\section{JEBEL QATRANI FORMATION (LOWER OLIGOCENE)}

\section{INTRODUCTION}

Said (1962) supplanted Beadnell's (1905) term "fluvio-marine series" with "Gebel Qatrani Formation" or "Qatrani Formation" for the variegated sandstones, gravelly sandstones, sandy mudstones, limestones, and shales that make up the El Ekhwat el Talata Escarpment and the Jebel Qatrani at the northern margin of the Fayum Depression (fig. 1; fig. 2D, E, F). In its type area, the formation is about $340 \mathrm{~m}$ thick; however, the unit thins considerably to the west, reaching less than $200 \mathrm{~m}$ in the Sarab Mukhafet area and less than $100 \mathrm{~m}$ at Madwar el Bighal. The Jebel Qatrani Formation is also less than $100 \mathrm{~m}$ thick in a restricted area about 25-32 km east of Wadi Kadish. To the east, the Jebel Qatrani Formation appears to be thinnest (about $50 \mathrm{~m}$ ) in the vicinity of the basalt mine (fig. $1 B$ ), but it thickens to nearly $200 \mathrm{~m}$ at Elwaht Hialla.

The Jebel Qatrani Formation is readily distinguished from the underlying drab green and gray Dir Abu Lifa Member of the Qasr el Sagha Formation in its dominance of brightly variegated rocks, including red, purple, yellow, green, gray, and brown sandy mudstones, white, red, green, and gray sandstones, and brown and white gravelly sandstones. Limestones and shales together make up less than 3 percent of the Jebel Qatrani section. From the overlying alluvial Miocene Kashab Formation, the Jebel Qatrani is separated by an erosional unconformity, followed in places by up to $25 \mathrm{~m}$ of the Widan el Faras Basalt (Bowen and Vondra, 1974), a dense, iron-rich, cliff-forming unit capping the Jebel Qatrani for nearly $50 \mathrm{~km}$. In areas where the Widan el Faras Basalt is absent, the Jebel Qatrani Formation is overlain by the Kashab Formation with an erosional unconformity.

\section{DISTRIBUTION}

One objective of fieldwork was to reconnoiter the Jebel Qatrani northwest of Birket Qarun to search for exposures of continental Oligocene rocks farther afield in the Western Desert, between the Fayum Depression and the Bahariya Oasis. This exploration has added significantly to knowledge of the distribution, stratigraphic character, and facies relations of the Jebel Qatrani Formation. In the Fayum Depression and areas to the east, the exposure and topographic expression of the formation is controlled largely by the presence or absence of the Widan el Faras Basalt and by development of large east-west-trending normal faults. In places where the basalt is thick, the Jebel Qatrani Formation is well exposed in alternating benches and steep cliffs beneath it. The basalt thins to the west, north, and east of Widan el Faras (fig. $2 F$ ) and, where it is thin or absent, exposures of the Jebel Qatrani Formation are limited to local, isolated benches rising above the desert serir, or to scattered yardangs and blowouts. Exposures are also subdued on the downthrown sides of normal faults, particularly in the area between a point about $4 \mathrm{~km}$ north of Widan el Faras, eastward to the vicinity of Elwaht Hialla (fig. $1 B$ ).

Though thickest, best known, and best exposed in its type area in the vicinity of Widan el Faras, Jebel 
Qatrani rocks are exposed between this area and Cairo and, in the Eastern Desert, its equivalents are sporadically present as far eastward as the Bitter Lakes and as far to the south as the area of El Galala el Bahariya (Barron, 1907; Shukri, 1953; Shukri and Akmal, 1953; Said, 1962; Geological Survey of Egypt, 1981; see fig. $1 A$, this paper). In those areas, Oligocene alluvial rocks indistinguishable from the Jebel Qatrani Formation have been referred to the "Jebel Ahmar beds" (Fourtau, 1894) and are noted for their abundant silicified logs (Carruthers, 1870; Krausel, 1939) and rhizocretionary sandstones (Aghion, 1940). The Jebel Qatrani Formation is also exposed at Ma'adi, a suburb of southern Cairo, where the abundant fossil logs weathering from it are a local tourist attraction. Between Ma'adi and Widan el Faras, Jebel Qatrani rocks are preserved, though poorly exposed, at the middle and top of the escarpment Elwaht Hialla (Beadnell, 1905), about $30 \mathrm{~km}$ north of the village of Sinnouris (fig. $1 B$ ). There, Beadnell (1905) recorded a thickness of only 90 $\mathrm{m}$ of the "fluvio-marine series," including basalt; however, Vondra (written commun., 1982) provides a more correct figure near $200 \mathrm{~m}$. West of Elwaht Hialla, in the vicinity of the basalt mine, the Jebel Qatrani Formation is exceedingly thin, perhaps less than $50 \mathrm{~m}$, and appears to be made up largely of rocks equivalent to those of the lower half of the formation elsewhere.

From Widan el Faras southwest some $35 \mathrm{~km}$ to a point about $10 \mathrm{~km}$ southwest of Naqb el Garw (figs. 1, $2 B$ ), the Jebel Qatrani Formation is well exposed and appears to maintain a more or less even thickness. Farther west along the Jebel Qatrani, between Tel Torisha and Wadi Kadish (fig. $2 A, B$ ) the formation thins rapidly to less than $100 \mathrm{~m}$, the thinning probably resulting from buried anticlinal folds active during the early Oligocene. However, at Wadi Kadish, the formation appears again to have thickened to about $200 \mathrm{~m}$. The Widan el Faras Basalt is absent west of Naqb el Garw, probably reflecting both distance from source vents (believed to be situated to the northeast) and erosion following basalt extrusion but prior to deposition of the lower part of the Kashab Formation. However, many units in the lower part of the Jebel Qatrani Formation are not only present but are readily traced farther west across this area of greatest formation thinning. These relationships demonstrate that the westward thinning is probably due to reduced net deposition over buried structural highs and not to postdepositional erosion or facies intertonguing with the underlying Dir Abu Lifa Member of the Qasr el Sagha Formation.

About $60 \mathrm{~km}$ southwest of Widan el Faras the Jebel Qatrani turns sharply southward and its continuity is broken by two eastward-reaching salients, Madwar el
Bighal, and a large outlier, Garet Gehannam, in the western Fayum Depression (fig. 1B). These features are developed on the upper Eocene Birket Qarun and Qasr el Sagha Formations, and the Madwar el Bighal salients merge westward with the combined Qasr el Sagha Escarpment and the Jebel Qatrani, there capped by about $50-150 \mathrm{~m}$ of the Jebel Qatrani Formation. The greater of these thicknesses is preserved in and north of the circular Sarab Mukhafet (fig. 1B), about $15 \mathrm{~km}$ north of Madwar el Bighal, and at Wadi Kadish. There, the Jebel Qatrani Formation contains very little mudstone or other flood plain deposits, the rocks are drabber than farther east, and the sands are, in general, better cemented with calcium carbonate than in the type area. South of Madwar el Bighal and west of Wadi el Ruwayan, the Jebel Qatrani Formation is at least locally absent, though the Geologic Map of Egypt (Geological Survey of Egypt, 1981) indicates its presence there as well as much farther to the south, depicting Oligocene rocks covering a vast area of the Western Desert between the Fayum Depression and the Bahariya Oasis.

Northwest of Madwar el Bighal, rocks of the Jebel Qatrani Formation merge with and are covered by dune sand and the Western Desert serir. It is likely that the formation as well as upper Eocene rocks exist beneath this serir as far west as the west-facing breaks some $50-80 \mathrm{~km}$ east of the village of El Bawiti in the Bahariya Oasis (fig. 1A), as is depicted on the Geologic Map of Egypt. Our reconnaissance work suggests that the lower part of the Jebel Qatrani Formation is exposed in the vicinities of Seton Hill, Garet el Hamra, and Garet el Ghaziya, east of the Bahariya Oasis (fig. $1 A$ ). Ball and Beadnell (1903), Beadnell (1905), and Attia (1950) believed that sedimentary iron ores capping Jebel Ghorabi were Oligocene; however, they are now known to be middle Eocene (Faris and others, 1956; Said, 1962). The ferruginous "silicified grits and puddingstone" that cap hills between Garet el Hamra and the "chief bone-bearing localities in the north of the Fayum" that Beadnell (1905, p. 67) believed might be equivalent to his "fluvio-marine series" (Jebel Qatrani Formation) were not encountered during our reconnaissance survey of that area. Nonetheless, similar deposits cap Garet Harra and other hills in the eastern and northern parts of the Bahariya Oasis area (Said, 1962; G. Franks, oral commun., 1981), as well as Garet Hamid and Garet el Hamir, north and northeast, respectively, of Widan el Faras (fig. $1 B$ ). Some of these deposits adjoining the Bahariya Oasis have been assigned to the Radwan Formation, provisionally of Oligocene age, whereas those north of the Jebel Qatrani appear to belong to the Miocene Kashab Formation. Nonetheless, the ages of all of these ferrugi- 


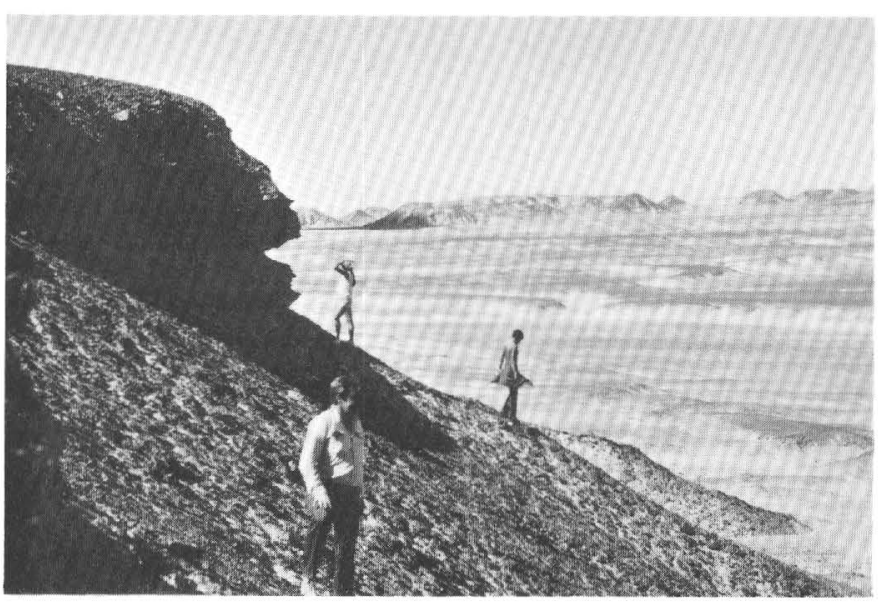

FIGURE 15.-Hills (in foreground and distance) capped with conglomerate of sedimentary iron ore. View to northeast of exposures about $20 \mathrm{~km}$ south-southwest of El Bawiti, Bahariya Oasis, Western Desert of Egypt.

nous silicified sandstones remain uncertain; none of them closely resemble lithologies of the Jebel Qatrani Formation in its type area.

About $10-30 \mathrm{~km}$ south of the village of El Bawiti in the Bahariya Oasis, the generally flat countryside is broken by numerous conical hills and tablelands that are capped variously by basalt flows or by dark conglomeratic sedimentary iron ore (figs. 15, 16). These rocks were included in the Cretaceous Series on the Geologic Map of Egypt (Geological Survey of Egypt, 1981), but close inspection of the iron-rich conglomerates indicates that they are almost surely younger, as originally observed by Ball and Beadnell (1903). The conglomeratic sedimentary iron deposits lie atop variegated sandstones with a pronounced erosional contact (up to $10 \mathrm{~m}$ of relief) and are quite similar to sedimentary iron deposits developed in situ in Eocene host rocks at the nearby Gedida Iron Mine (fig. $1 A$ ), some $30 \mathrm{~km}$ northeast of El Bawiti. If these sedimentary iron ores prove to be the source of the conglomeratic clasts (and no other source is apparent), the units capping the buttes must be Eocene or younger, perhaps Oligocene in age. The size of the largest conglomerate clasts (up to 0.7 -m-long axis) indicates a proximal source. Moreover, much of the underlying truncated variegated sandstone closely resembles Jebel Qatrani rocks elsewhere and is unlike the drab Cretaceous rocks exposed in other areas of the oasis. Until the conglomerate and associated underlying variegated rocks can be dated, their relations and ages will remain unclear.

\section{LOWER CONTACT}

The Jebel Qatrani Formation overlies the upper part of the Qasr el Sagha Formation with apparent ero-

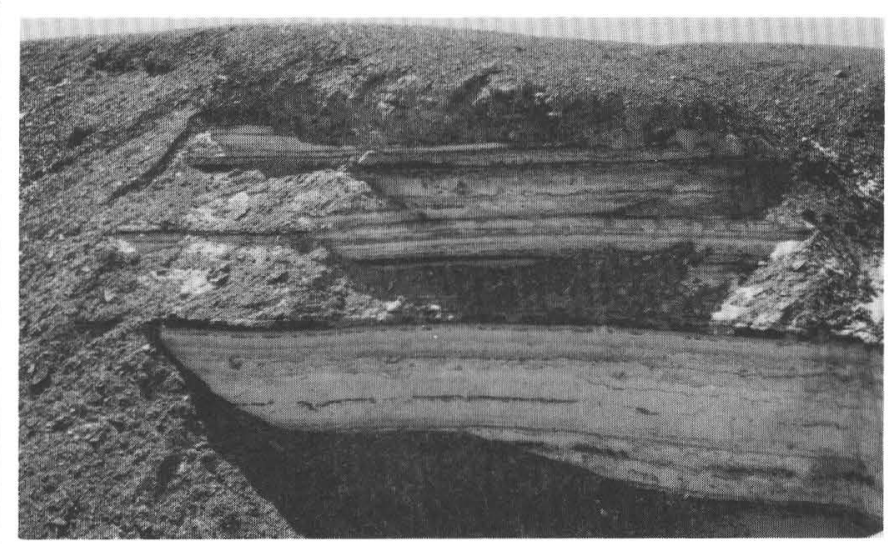

FIGURE 16.-Conglomerate of sedimentary iron ore lying in scour developed on variegated fluvial rocks, about $20 \mathrm{~km}$ southsouthwest of El Bawiti, Bahariya Oasis, Western Desert of Egypt. Depth of scour at this site is approximately $5 \mathrm{~m}$.

sional unconformity everywhere the base of the formation is exposed in the Fayum Depression. In most areas the contact is picked at the top of the "bare limestone" sequence, though other Qasr el Sagha beds (upper crossbedded sandstone and mudstone sequence) locally are preserved. Though a case could be made for lowering the contact to include the largely alluvial Dir Abu Lifa Member of the Qasr el Sagha Formation in the Jebel Qatrani Formation, in some areas lateral to the Qasr el Sagha type area the Dir Abu Lifa Member is absent beneath the "bare limestone" sequence and where present it contrasts markedly with the overlying brightly variegated beds typical of the Jebel Qatrani Formation. Moreover, Dir Abu Lifa rocks above the giant crossbedded sandstone sequence include several marine intercalations. The "bare limestone" sequence, though not an ideal formation boundary unit, also marks the final phase of marine deposition in this part of the Tertiary section.

Beyond the Alexandria Trail north of Garet Umm el Zalat at the west end of Birket Qarun (fig. $1 B$ ), the "bare limestone" sequence is developed as far west as $15 \mathrm{~km}$ west of Wadi Kadish, in the area of Madwar el Bighal, at the west margin of the Fayum Depression (fig. $1 B$ ). In those areas, the lowest beds of the Jebel Qatrani consist of friable gravelly white sandstone containing silicified wood fragments, or of well-cemented green or white sandstone, commonly with densely packed rhizolith masses (fig. 17). These beds lie with apparent conformity on the bare limestone sequence, there overlying an unusually thick section of the Dir Abu Lifa Member of the Qasr el Sagha Formation. The lowest beds of the Jebel Qatrani Formation are there overlain by nearly $200 \mathrm{~m}$ of drab, yellow and green gravelly sandstone and minor amounts of variegated sandy mudstone. 

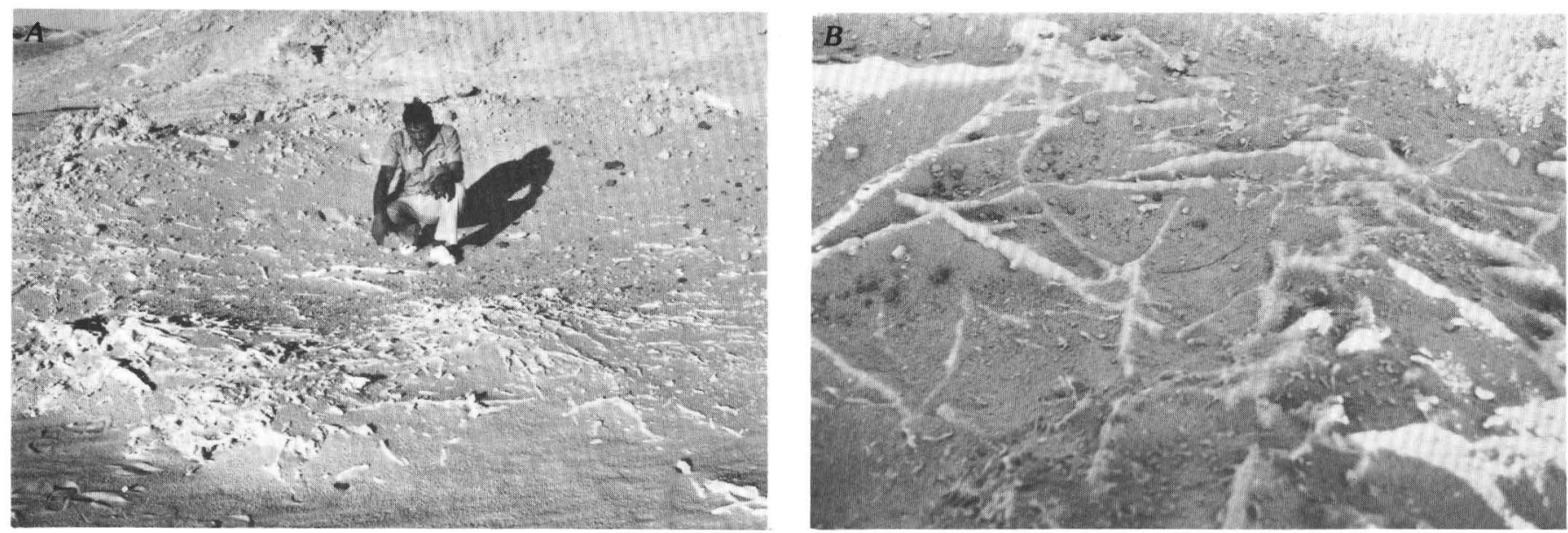

Figure 17.-Rhizoliths at Sarab Mukhafet, western part of the Fayum Depression, Jebel Qatrani Formation. A, Rhizoliths, probably of mangroves, exposed by deflation on exposed surface. $B$, Nonmangrove rhizoliths exposed by deflation. Frame for $B$ shows about $3 \mathrm{~m}$ from top to bottom.

At Elwaht Hialla, east of Widan el Faras, Beadnell (1905) observed that the "fluvio-marine series" (Jebel Qatrani) rocks are much thinner than they are farther west and that the contact with the Qasr el Sagha, though "conformable," is with beds lower in the Qasr el Sagha section than in the type area (with those rocks of the Temple Member, as used here). Beadnell attributed this relationship to an earlier onset of Jebel Qatrani environments at Elwaht Hialla; however, it appears instead to have resulted from the absence of deposition of the Dir Abu Lifa Member of the upper Qasr el Sagha Formation. In the Eastern Desert, the Jebel Ahmar beds (=Jebel Qatrani Formation equivalents) lie unconformably on all older rocks.

\section{LITHOLOGY}

The Jebel Qatrani Formation was examined by us in detail in a quadrangle containing much of the top of the Qasr el Sagha Escarpment, all of the El Ekhwat el Talata Escarpment, and much of the Jebel Qatrani (fig. $1 C$ ). This area is approximately bounded on the south by a line connecting Garet Umm el Zalat (on the west) and Dir Abu Lifa (on the east), and it is bounded on the north by a line connecting Naqb el Garw (on the west) and Widan el Faras (on the east, fig. 2). It is here that the formation is thickest and best exposed and that most of the fossil localities yielding the important Fayum fossil vertebrate fauna are contained. As observed by Beadnell (1905), the character of the Jebel Qatrani Formation is essentially tripartite; we find that it consists of (1) a lower sequence dominated by coarse to gravelly friable sandstones (153 m="lower fossil wood zone" of Simons, in Simons and Wood, 1968), (2) a middle marker bed of cliff-forming medium- to coarse-grained gypsiferous sandstone $(7-10$ $\mathrm{m}=$ marker, or barite sandstone of this report; fig. 18), and (3) an upper sequence of variegated sandstone and sandy mudstone with a few lenses of gravelly sandstone and a few thin beds of limestone (about 190 $\mathrm{m}=$ "upper fossil wood zone" of Simons, in Simons and Wood, 1968).

The lower part of the Jebel Qatrani Formation is exposed on a broad, flat bench (up to $5 \mathrm{~km}$ wide) at the top of the Qasr el Sagha Escarpment that was formed by deflation of the gently dipping friable sandstones that make up most of this sequence. The upper part of the formation is exposed on a steeper and narrower upper bench (top of El Ekhwat el Talata Escarpment) where exposures are instead developed on friable sandstones and a higher proportion of more resistant fine sand and sandy mudstones. In general, the lower part of the Jebel Qatrani Formation is made up of units that can be traced laterally for great distances (fig. 18), well west and east of the quadrangle studied most thoroughly by us. The marker, or barite sandstone that separates the lower and upper parts of the formation was traced west of the formation type area more than $60 \mathrm{~km}$ to Wadi Kadish (fig. $1 B$ ) and northeast of Widan el Faras for about $6 \mathrm{~km}$. The barite sandstone and the other large sand bodies in the lower part of the formation are coalesced channel deposits that are both multistory and multilateral. Most of the originally deposited floodplain mudstones were reworked as channels migrated laterally. In contrast, floodplain mudstones account for significantly more of the volume of the upper part of the formation, and the pervasive intertonguing of sandstones and mudstones in that part of the section results in greater lateral discontinuity of these units; most cannot be traced for more than a few kilometers and generally less. Therefore, both lithostratigraphic 


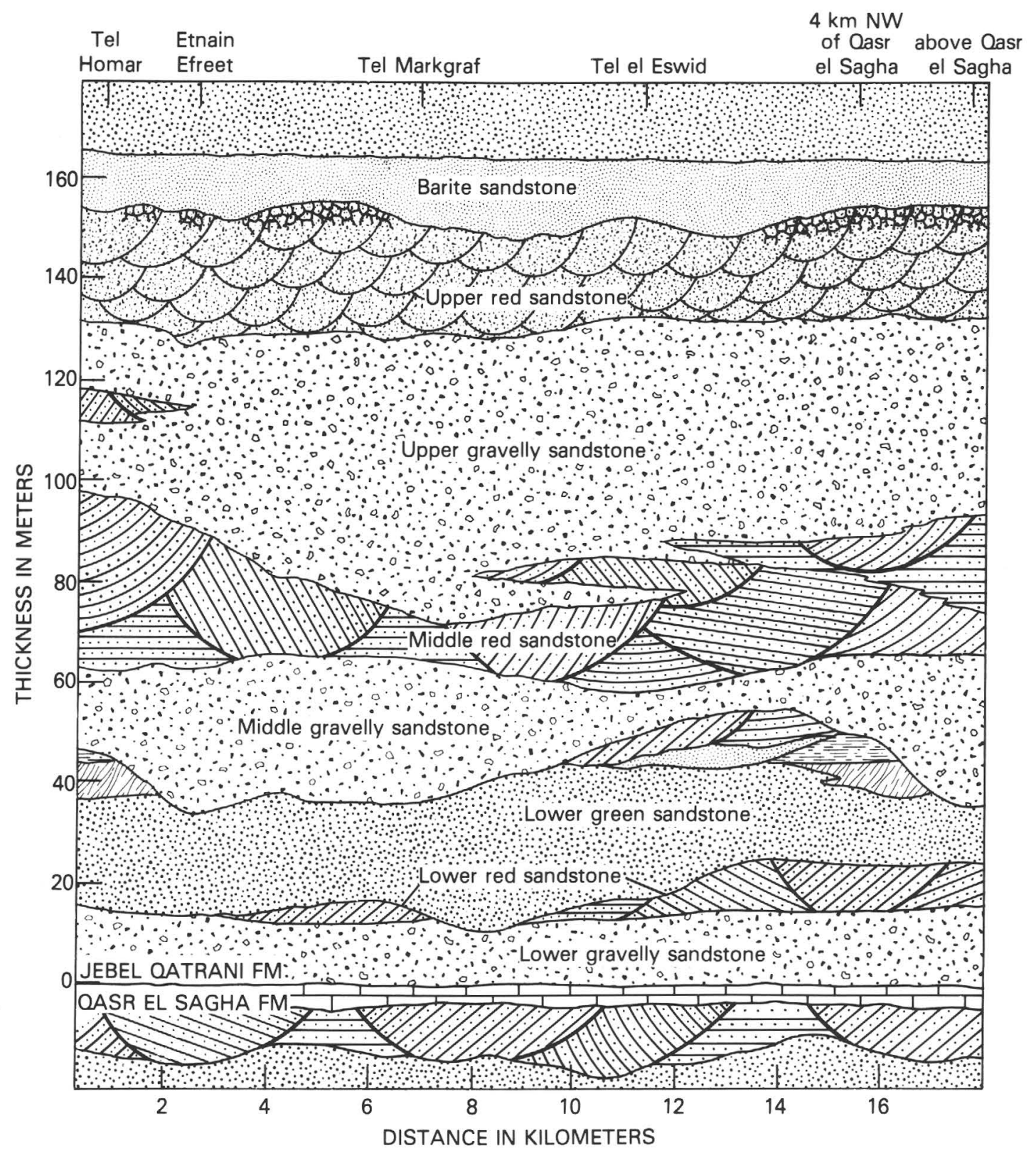

FIGURE 18.-Diagram showing relations of units in the lower part of the Jebel Qatrani Formation in the region between Tel Homar and a point on the Qasr el Sagha Escarpment due north of the Qasr el Sagha Temple. The lower and upper variegated sequences of the lower part of the Jebel Qatrani Formation are depicted as two laterally discontinuous sequences above the lower green sandstone sequence and truncated over most of this area by scour at the base of the middle gravelly sandstone sequence.

and biostratigraphic control is best defined for the lower $160 \mathrm{~m}$ of the Jebel Qatrani Formation.

\section{LOWER SEQUENCE OF \\ JEBEL QATRANI FORMATION}

In stratigraphic arrangement, the lower sequence of the Jebel Qatrani Formation in its type area is divisible into the units shown in figures 18 and 19 .
The lower, middle, and upper gravelly sandstone sequences are composed of white and yellow mediumcoarse sand with occasional stringers, lenses, and interbeds of gravel. Yellow mottling is pervasive in some of the white sands and red mottling is encountered more rarely. The sandstones are generally friable but may have local areas of calcium-carbonate cement, especially in the lower 1 or $2 \mathrm{~m}$. These units are clearly 
recognized in the field by their surficial peach color (imparted by mixing of outcrop sand and the coarser particles of dune sand), surface-lag accumulations of chert pebbles, and overall lack of consolidation which causes these units to be expressed as the tops of vast benches above and below more resistant units. The units are also characterized locally by abundant silicified wood, occurring both as logs and smaller fragments. Fossil vertebrate remains, located by concentrations of white coprolites, occur locally in the middle and upper gravelly sandstone sequences. Rhizoliths and animal bioturbation are common and are most obvious and best preserved in the cemented portions of these units, where deflation of the surrounding friable host rock causes them to be exhumed in bas relief.

Both the coarsest and the finest sand in the gravelly sandstone sequences is composed dominantly of quartz, though chert and feldspar are common. Grain roundness varies from angular to moderately well rounded; most of the pebbles and granules of chert are moderately well rounded. The chert pebbles are commonly associated with mudstone clasts and occur at the bases of large-scale trough and tabular crossbed sets. In some areas, cross stratification is well exposed in plan view on the upper bedding surfaces of these sandstones (fig. 20). Paleocurrent directions obtained from large-scale cross stratification in the lower gravelly sandstone sequence yield a mean bearing of $276^{\circ}$ (seven measurements).

"Forests" of a few to about 200 logs are common in the middle and upper gravelly sandstone sequences, but logs are relatively rare in the lower gravelly sandstone sequence. The logs are iron-silica petrifactions and those that are best preserved have the greatest silica content (fig. 21A). Logs resembling masses of rotten wood (fig. $21 B$ ) appear to be composed principally of limonite. Two major log fields occur (fig. $21 C$ ); both are in the middle gravelly sandstone sequence, and they contain about 60 and 200 logs, respectively. We record 7 instances of root flares at the bases of the $\log$ boles (fig. $21 \mathrm{~A}$ ) and 12 instances of branchings of the logs (Bown and others, 1982, pls. 2b, 2c). The longest log measured is $44 \mathrm{~m}$ and is incomplete. Taxa of Oligocene woods of Egypt (including those of the Jebel Qatrani Formation) were published by Krausel (1939) and discussed further by Wing and Tiffney (1982; and in Bown and others, 1982, p. 611-614). Other plant remains are rare in the lower part of the Jebel Qatrani Formation; however, one locality (probably in the middle gravelly sandstone sequence) has yielded about 30 specimens of compound fruits of the liane Epipremnum (fig. $11 D$ ), associated with poorly preserved limonitic fossil logs and possibly vines. None of the fossil logs occur in growth position, and sedimentologic evidence indicates that most were transported a short distance prior to burial. Orientations taken on about 200 logs at the two major log localities discussed above yield mean orientations of $319^{\circ}$ and $308^{\circ}$, respectively (fig. 22), and indicate current orientation of the logs, probably approximately parallel to flow (but see MacDonald and Jefferson, 1985). Small pieces of waterworn fossil driftwood are abundantly associated with the fossil logs at one locality in the middle gravelly sandstone sequence (fig. 11E). The origin of the forests of the Jebel Qatrani Formation has been debated for well over a century. As recently as 1980 it was suggested that the logs were derived from areas far to the south and that they were rafted to their present positions by an ancestral Nile River (Kortlandt, 1980). There is no geological or paleobotanical evidence to support this contention (Bown and others, 1982).

The lower, middle, and upper gravelly sandstone sequences are multistory and multilateral units; that is, they consist of vertically and laterally coalesced deposits of many channels. Poor exposure and poor threedimensional control, owing to the friable nature of these units, makes it very difficult to visualize relationships of channels to one another, but local observations show that the lower contacts of these channels are erosional, as are the bases of at least two of the compound multistory sequences themselves. The lower gravelly sandstone sequence has a relatively minor erosional relationship with the underlying Dir Abu Lifa Member of the Qasr el Sagha Formation; however, lateral relationships demonstrate that the base of the middle gravelly sandstone sequence is a major scour surface with up to $20 \mathrm{~m}$ of regional relief (fig. 18). Within the area of study, channels of the upper gravelly sandstone sequence have cut deeply into the underlying middle red sandstone sequence to the west, but the lower part of the upper gravelly sandstone sequence intertongues with the middle red sandstone sequence and overlies it, or a similar sequence, southeast of Widan el Faras. The lower, middle, and upper gravelly sandstone sequences are locally uraniferous (Shazly and others, 1974).

In the Wadi Kadish area and for some kilometers east of there, the entire lower part of the Jebel Qatrani Formation is made up of a single gravelly sandstone sequence, the upper red sandstone sequence and the barite sandstone sequence, reflecting less volumetric significance of overbank sediments in this part of the section to the west. It is unknown which of the three (or all) of the gravelly sandstone sequences is represented.

The lower, middle, and upper red sandstone sequences are composed of fine to coarse sand with volumetrically insignificant amounts of coarse silt and gravel. Locally, variegated mudstones intertongue with the upper red sandstone sequence or are preserved 


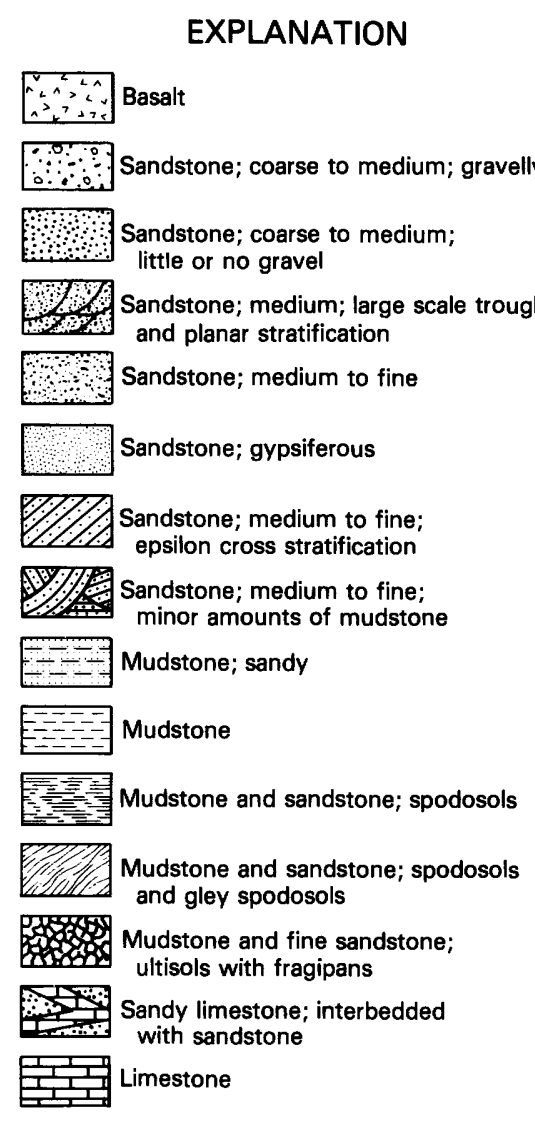

Paleocurrents (top of column is north)

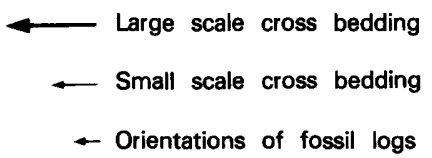

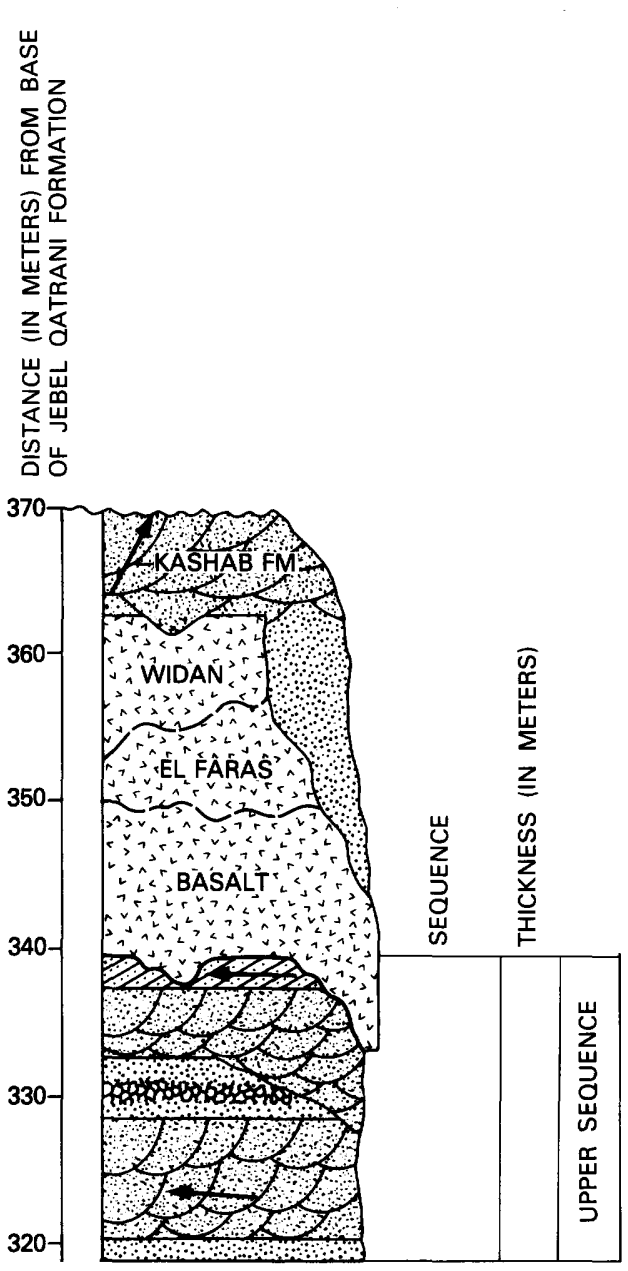

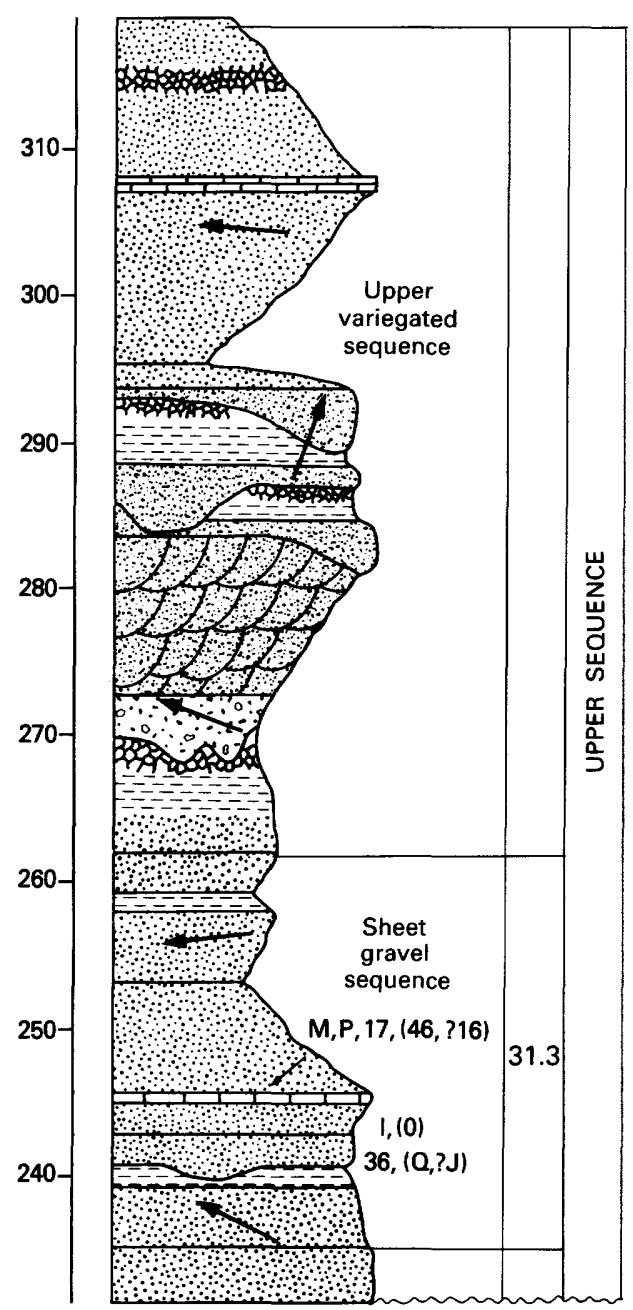

FIGURE 19.-Stratigraphic column showing lithologies, paleocurrent directions, and stratigraphic arrangement of fossil vertebrate localities (numbers and letters to right of columns) in units of the Jebel Qatrani Formation along the lines of section depicted in figure 1C. "Distance (in meters)" to left of columns indicates cumulative thicknesses of rocks above or below base of Jebel Qatrani Formation, with base of that formation designated by " 0 ." as erosional remnants within it. Like the gravelly sandstone sequences, the red sandstone sequences are tabular, multistory bodies with erosional lower contacts (fig. 18).

The lower and middle red sandstone sequences are easily recognized by their pervasive brick red coloration from oxidized iron minerals; however, these units exhibit laterally abrupt color changes from red to green or red to brown. The two lowest of the red sandstone sequences consist of large-scale epsilon cross strata which internally contain large-scale trough or tabular cross stratification and horizontal stratification. The large-scale trough cross stratification and horizontal stratification grade upward into grouped sets of small-scale trough cross stratification that have some silty sandstone cross laminae. Large-scale cross stratification in the lower red sandstone sequence indicates that flow was essentially from east to west. Though cross stratification from the middle red sandstone sequence is more variable, it also indicates paleoflow from east to west.

About $3.5 \mathrm{~km}$ north-northwest of Qasr el Sagha Temple, the middle red sandstone sequence overlies and intertongues with a striking sequence of alternating golden sandstones and deep yellow to gray-green silty sandstones. These rocks also exhibit epsilon cross stratification; internal stratification of the cleaner sands, though poorly preserved, appears to be horizontal. At the sequence's easternmost exposure, these drab units contain abundant large-scale load structures. 


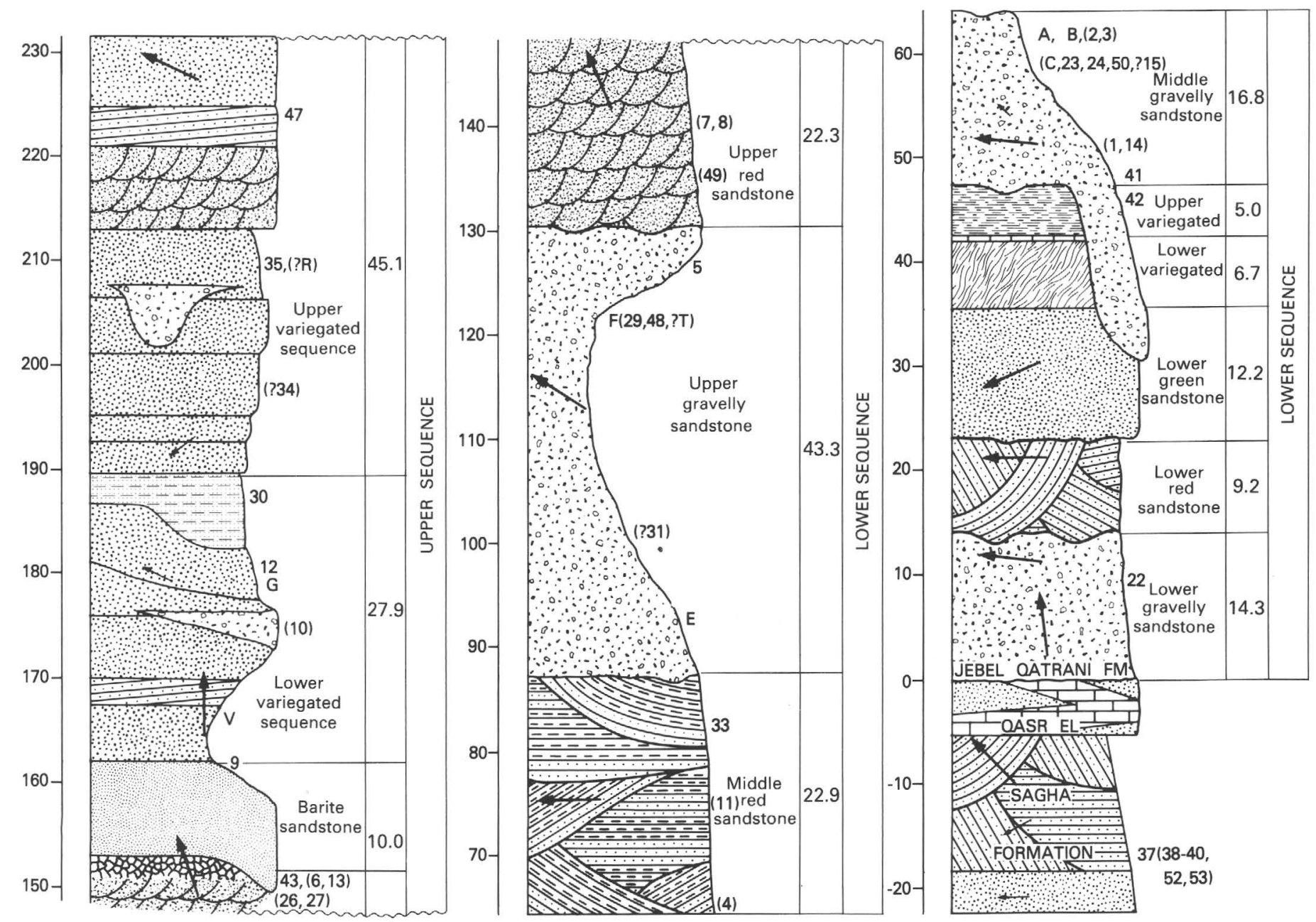

Figure 19.-Continued

The upper red sandstone sequence is developed over the entire study area beneath the barite sandstone (figs. 18, 23). This sequence is somewhat coarser on the average than either the lower or middle red sandstone sequences (medium to coarse sand), and in some areas the color is dominated by orange, green, and brown iron oxyhydrates rather than red dehydrated iron oxides. The upper red sandstone sequence is dominated by large-scale sets of trough and tabular cross stratification that show flow directions varying from due north to northwest, a significant departure from the principally western flow that laid down most of the lower units. Epsilon crossbeds are locally well developed (fig. $23 A-C$ ), and large mud ripup clasts occur locally in this unit (fig. $23 D$ ). At some localities in the upper red sandstone sequence, relatively complete cross sections of individual paleochannels are exposed, allowing measurements of channel sizes. For the most part, streams contributing sediment to the multistory upper red sandstone sequence were no more than about $12 \mathrm{~m}$ in depth and approximately $100 \mathrm{~m}$ in width (fig. $23 \mathrm{C}$ ).

Fossil wood is rare in the red sandstone sequences and where it is found it is generally very poorly preserved. Significant accumulations of crocodile, turtle, fish, and mammal remains occur locally in the middle red sandstone sequence, and concentrations of vertebrate remains of all kinds (but no major localities) are known from the upper red sandstone sequence. Rhizoliths, nest and gallery structures of subterranean termites, probable crayfish burrows, and numerous other 


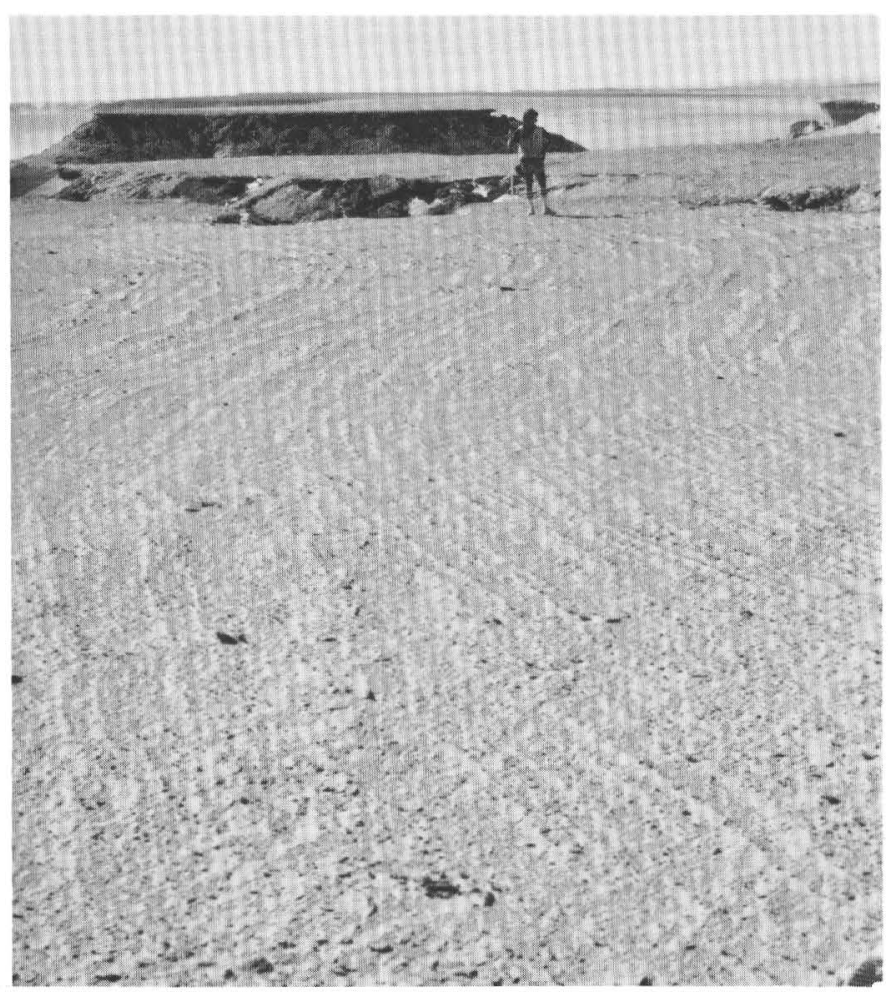

Figure 20.-Bar tops exposed by deflation in the base of the middle gravelly sandstone sequence of the lower part of the Jebel Qatrani Formation, about $3.3 \mathrm{~km}$ west-northwest of the Qasr el Sagha Temple. View to southwest.

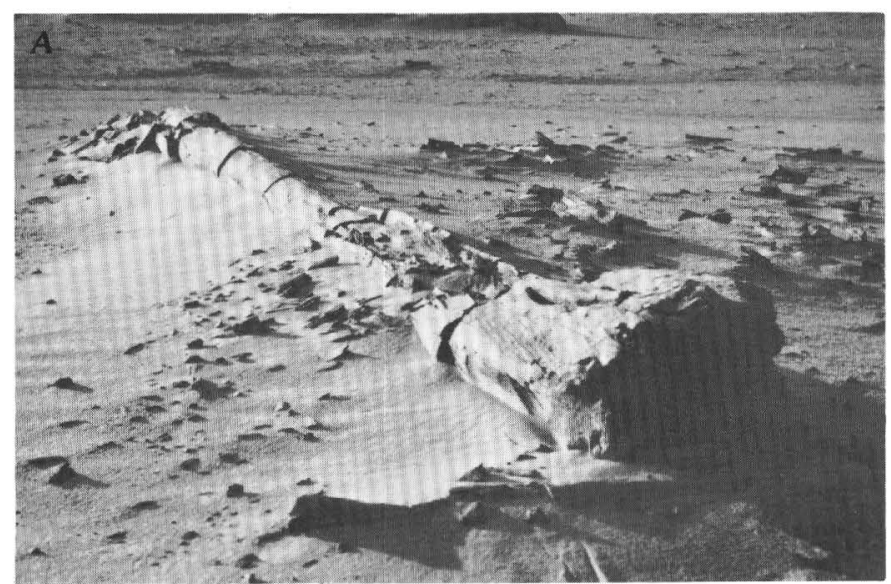

Figure 21.-Fossil logs, lower part of the Jebel Qatrani Formation. $A$, Iron-silicate petrifaction of well-preserved fossil $\log$ in major $\log$ field, middle gravelly sandstone sequence, about $2.8 \mathrm{~km}$ northwest of Dir Abu Lifa. Log is $27 \mathrm{~m}$ long. B, Iron-silicate petrifaction of fossil $\log$ in middle part of middle gravelly sandstone sequence, about $1.5 \mathrm{~km}$ west of Tel Taleb. Log contains a much higher proportion of iron oxyhydrate minerals to silicates than the log depicted in $A$, and therefore is much less well preserved. $C$, Small part of the principal fossil log field in the lower part of the middle gravelly sandstone sequence, about $2.8 \mathrm{~km}$ northwest of Dir Abu Lifa. Field contains at least 200 well-preserved logs, most of which appear to have been aligned by currents (see also fig. 22). View to west; log in foreground in $9 \mathrm{~m}$ long.
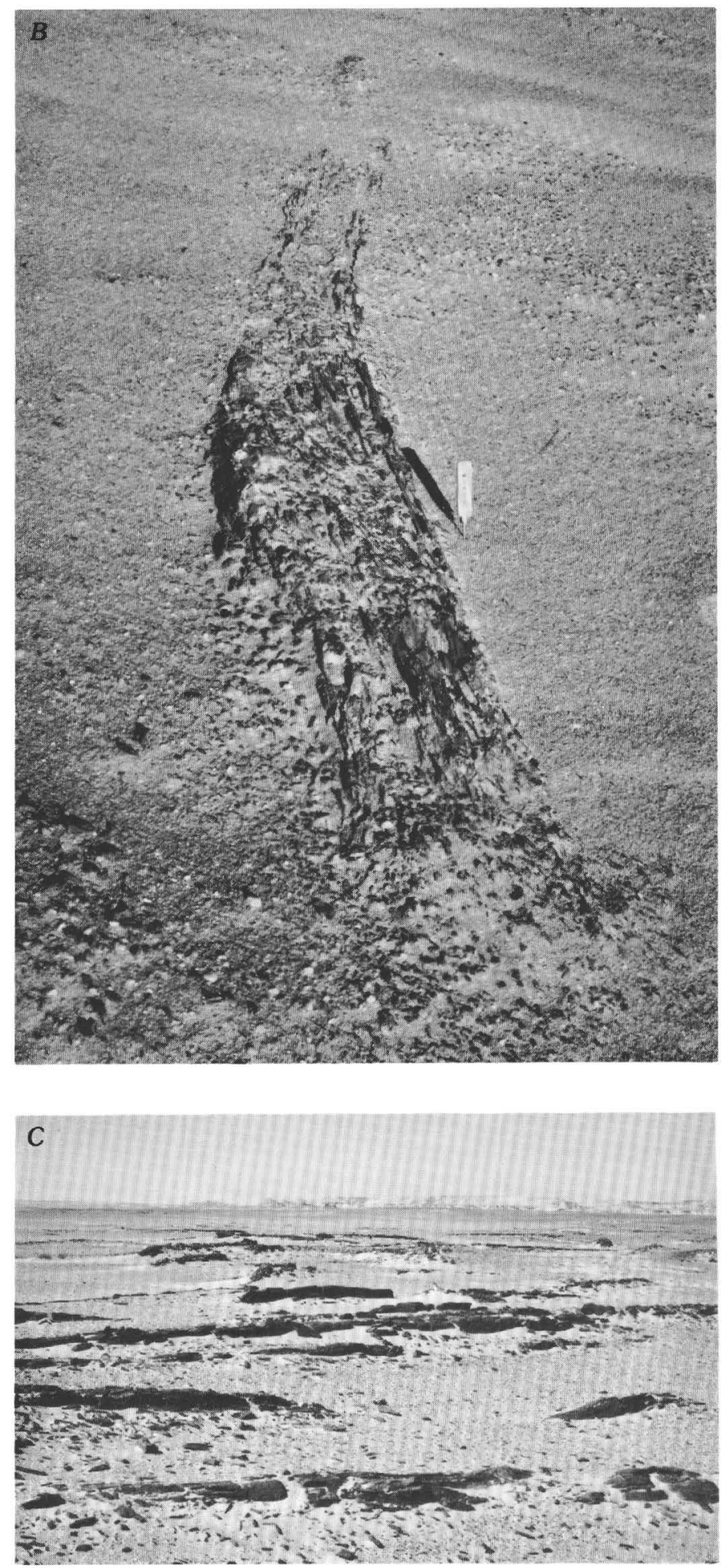


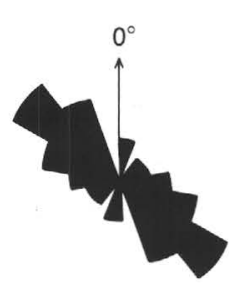

A

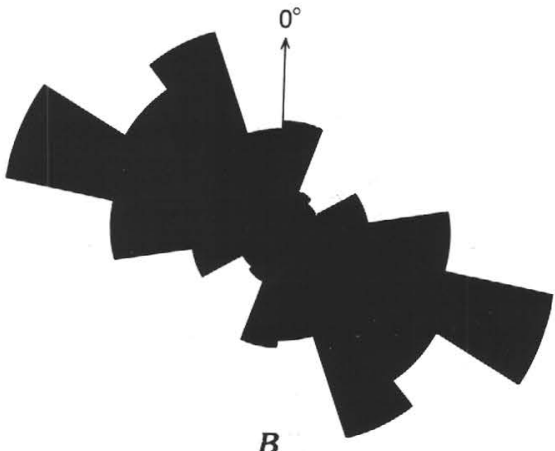

FIGURE 22.-Rose density diagrams showing long axis orientations of fossil logs at two major concentrations in the lower part of the middle gravelly sandstone sequence of the lower part of the Jebel Qatrani Formation. A, From small log field about $3.0 \mathrm{~km}$ westnorthwest of Dir Abu Lifa (60 logs). $B$, From major log field about $2.8 \mathrm{~km}$ northwest of Dir Abu Lifa (155 logs).

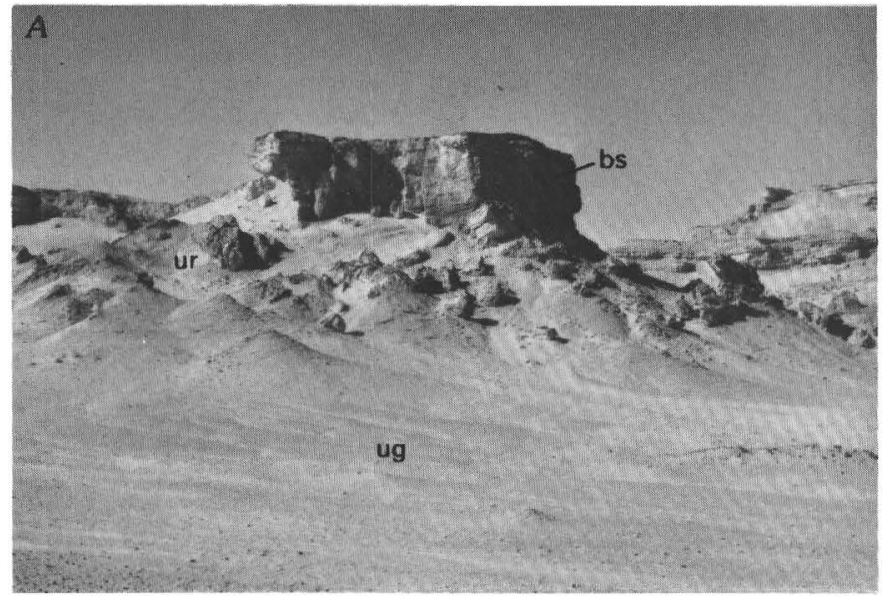

FiguRE 23.-Rocks of the upper part of the lower Jebel Qatrani Formation. A, Upper gravelly sandstone (ug), upper red sandstone sequence (ur), and barite sandstone (bs), as exposed about $2 \mathrm{~km}$ west of Tel el Eswid. Note large-scale epsilon cross stratification at top of upper red sandstone sequence. Top of butte is about $30 \mathrm{~m}$ above the desert valley floor. $B$, Isolated butte showing steep epsilon cross stratification in middle part of upper red sandstone sequence, about $2 \mathrm{~km}$ southeast of Widan el Faras. View to southeast. $C$, Channel scour descending to right and both filled with and truncating epsilon cross stratification in upper part of upper red sandstone sequence, about $2.5 \mathrm{~km}$ south-southeast of Widan el Faras. From this and other cross sections of channels it has been determined that many streams contributing sediment to this part of the Jebel Qatrani section were about $100 \mathrm{~m}$ wide and about 12-15 m deep. $D$, Large ripup clasts of sandy mudstone (arrows) near base of channel scour in lower part of upper red sandstone sequence, about $1 \mathrm{~km}$ south of Tel Markgraf. These attest to the erosion of most of the formerly present floodplain deposits in the lower part of the Jebel Qatrani Formation.
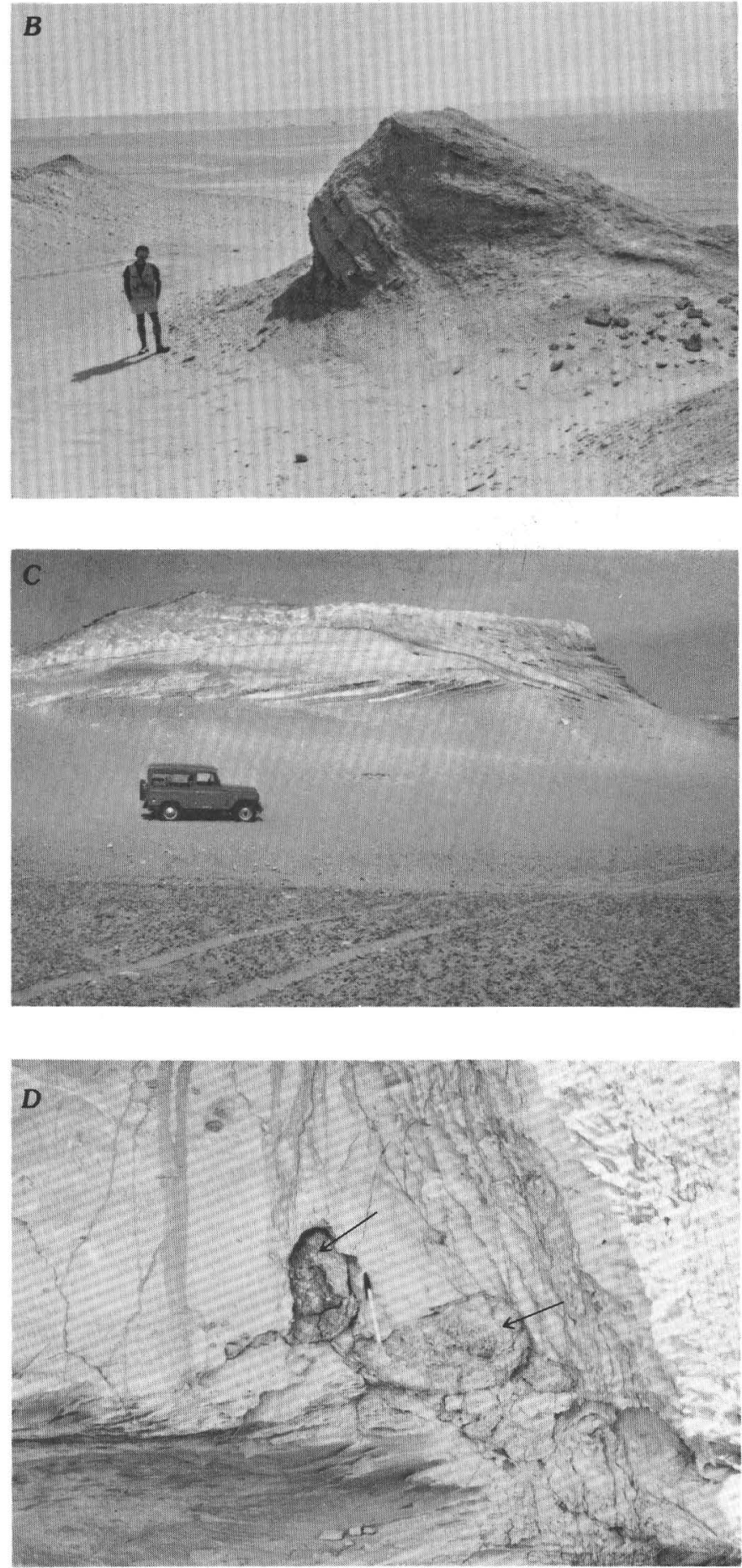


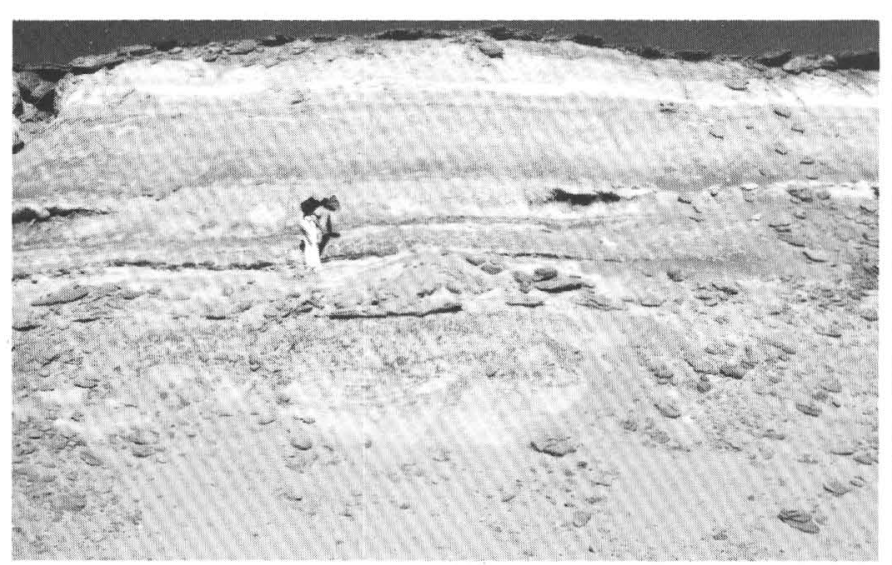

FIGURE 24.- Rocks of the lower and upper variegated sequences of the lower part of the Jebel Qatrani Formation, about $3.3 \mathrm{~km}$ westnorthwest of the Qasr el Sagha Temple. Contact is irregularly developed white sandstone developed at either side at the level of the geologist's head.

trace fossils occur in the red sandstone sequences (Bown, 1982), and these structures commonly originate from cross-stratified set boundaries.

The lower and upper variegated sequences (fig. 24) are dominated by relatively fine grained floodplain sediments, mostly fine sand, sandy mud, and mud. These units are preserved at only two sites within the study area and they account for the only appreciable fraction of floodplain deposits preserved in the lower sequence of the Jebel Qatrani Formation. Over most of the study area, both variegated sequences were deeply scoured and removed by erosion preceding deposition of

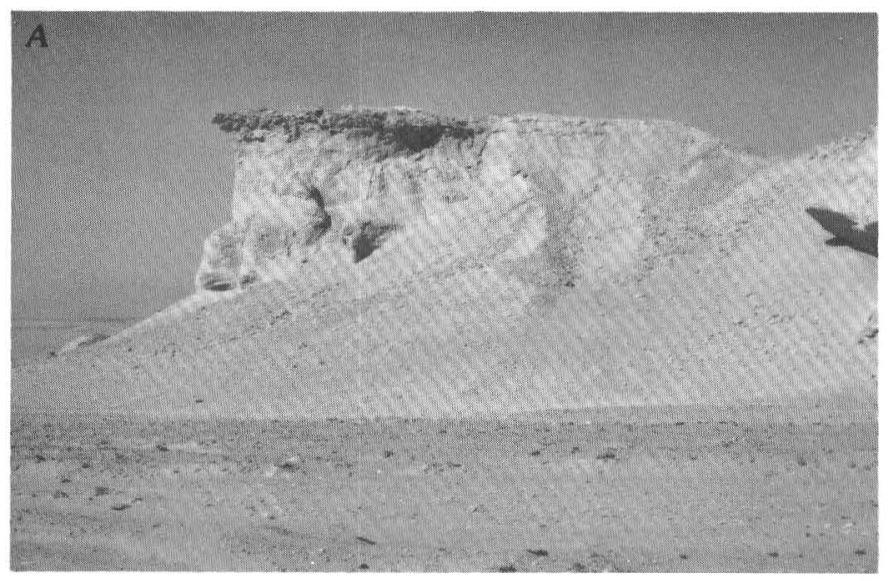

FiguRe 25.-Rocks of the lower green sandstone sequence of the lower part of the Jebel Qatrani Formation. A, Sequence as exposed about $3.1 \mathrm{~km}$ west-northwest of the Qasr el Sagha Temple. Rugose rocks capping ridge on left consist of calcium carbonate cemented rhizolith mats and poorly preserved trace fossils of subterranean termites. View to west; cliff is $21 \mathrm{~m}$ high. $B$, Upper $10 \mathrm{~m}$ of lower the middle gravelly sandstone sequence (fig. 18). The variegated sequences are highly distinctive and are exposed as steep scarps of red, purple, yellow, blue, green, and brown sediment in colored bands a few centimeters to more than $3 \mathrm{~m}$ in thickness. The upper variegated sequence is separated from the lower variegated sequence by a pedogenically altered white sandstone 10 to $80 \mathrm{~cm}$ thick. This unit would have little significance (most Jebel Qatrani sediments show paleopedologic modifications; see later section on "Paleosols") were it not for the fact that its level marks a zone of erosion west of its exposure along the line of section, and the unit appears again some $12 \mathrm{~km}$ to the west (fig. 18). It is also the source of bizarre helical burrows (probably produced by vertebrates) that are otherwise unknown in the Jebel Qatrani Formation (Bown, 1982, fig. 13CE). Pervasive alteration by soil-forming processes and bioturbation by invertebrates (Bown, 1982, fig. 12C, $D$ ) has largely destroyed internal stratification in the variegated sequences.

The lower green sandstone sequence (fig. 25) is a very persistent unit near the base of the Jebel Qatrani Formation. It is present $8 \mathrm{~km}$ northeast of Widan el Faras and continues south and west beyond that landmark at least to a point at the top of the Qasr el Sagha Escarpment above Garet Umm el Zalat, some $27 \mathrm{~km}$ west of Garet el Esh (fig. $1 B$ ), but is absent at Wadi Kadish. The unit lies with an erosional contact atop the lower red sandstone sequence over much of this area, but the latter unit is poorly exposed and (or) absent over large regions east of Widan el Faras and west of Garet el Esh. Above the Qasr el Sagha Temple (fig. $1 C$ ), the lower green sandstone sequence forms a

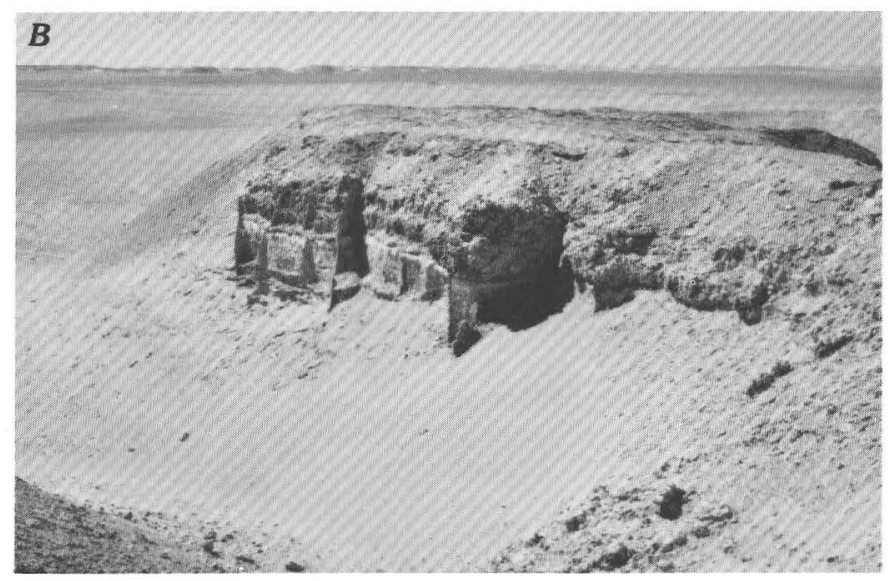

green sandstone sequence, as exposed about $2.0 \mathrm{~km}$ westnorthwest of exposure in $A$. At this locality and for about $2 \mathrm{~km}$ to the west, the upper $15 \mathrm{~m}$ of this unit is a massive sandy gypsum (selenite) with satin spar dikes. View to southwest toward Garet el Esh. 
low but distinctive bench just above the top of the Qasr el Sagha Escarpment, and is easily recognized from a distance by its highly distinctive pistachio green color. Along the line of section (fig. $1 C$ ), the lower green sandstone sequence is about $10-13 \mathrm{~m}$ thick, but it thins to about $5 \mathrm{~m}$ some $6 \mathrm{~km}$ northeast of Widan el Faras. West of the line of section, this sequence maintains a relatively even thickness but develops red mottling in the lower 3-4 m, eventually changing in color to a brick red (Bown, 1982, fig. 9A). About $2 \mathrm{~km}$ north of Garet el Esh, the upper part of the lower green sandstone sequence and all of the lower and upper variegated sequences have been removed by scour at the base of the middle gravelly sandstone sequence (fig. 18).

The base of the lower green sandstone sequence is generally a granular to pebbly sandstone with mud clasts and reworked limonite nodules and exhibiting horizontal bedding. This unit fines rapidly upward into medium- to coarse-grained sand that is greenish gray and appears massive, then again coarsens and displays thick $(1.1 \mathrm{~m})$ sets of trough or tabular cross stratification. Azimuths on these crossbeds indicate flow directions to the southwest and west-southwest. The lower half of the unit is somewhat friable but locally contains a few calcium carbonate cemented rhizolith masses. Gold mottles and thin gypsiferous sandstone interbeds are developed sporadically in the upper part of the unit, and these are commonly capped by $2-3$ meters of flaggy calcium-carbonate cemented sandstone. About $4 \mathrm{~km}$ northwest of Qasr el Sagha Temple, the upper part of the lower green sandstone sequence is locally replaced by up to $15 \mathrm{~m}$ of massive sandy gypsum (selenite; fig. $25 B$ ), but this lithology is not encountered elsewhere in the unit.

The lower green sandstone sequence contains no silicified wood or vertebrate remains, but is is noteworthy for its ichnofauna, particularly the hundreds of fossil nests of subterranean termites (Bown, 1982, figs. 3C, 7C-E, 9A). In two areas about $3 \mathrm{~km}$ northwest of Qasr el Sagha Temple, these nests are preserved as innumerable chalcedony, quartz, and calcite geodes (see also Beadnell, 1905, p. 61).

The nine sequences making up the lower part of the Jebel Qatrani Formation (figs. 18, 19) are, in the main, recognizable and distinctive over most of the bench region between Tel Homar and Wadi Ghorab at the top of the Qasr el Sagha Escarpment. In the Sarab Mukhafet and at Madwar el Bighal at the western extremity of the Fayum Depression (fig. $1 B$ ), the lower part of the formation is composed almost exclusively of gravelly sandstones and drab, well-indurated, multistory sheet sandstones that are rich in rhizoliths; rhizoliths of mangroves locally form dense mats and make up the lower $15-30 \mathrm{~m}$ of the formation over a wide area (fig.

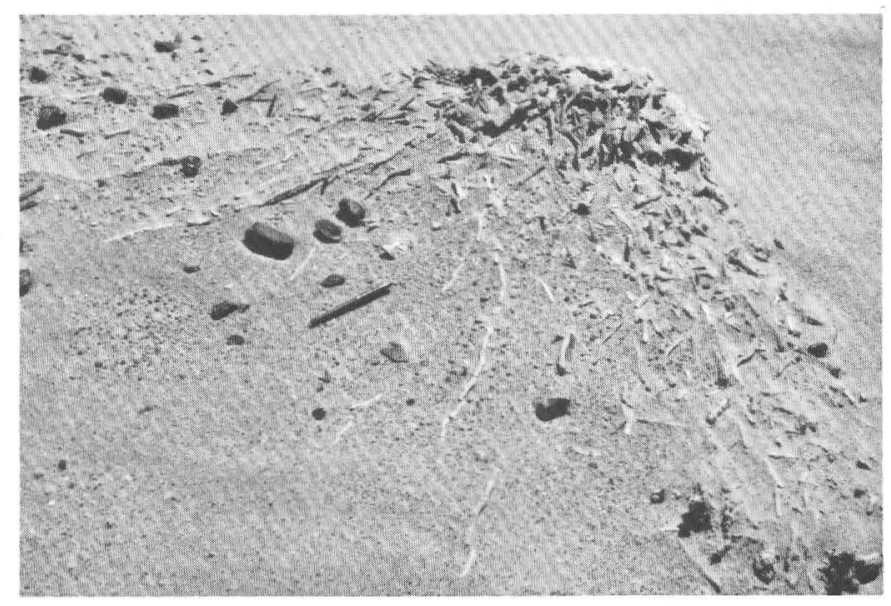

FIGURE 26.-Rhizoliths of stump and root system of a small mangrove in the lower part of the Jebel Qatrani Formation at the head of Wadi Kadish, western part of the Fayum Depression.

26). In the Sarab Mukhafet, this rhizolith unit is succeeded by about $40 \mathrm{~m}$ of interbedded greenish-gray sandstone and sandy mudstone, marly sandstones, and marls with occasional beds of brown or orange sandstone. In the northern part of the Sarab Mukhafet, the uppermost exposed Jebel Qatrani rocks are massive, multistory, cliff-forming sandstones that, in places, lie in scours cut up to $10 \mathrm{~m}$ into the underlying rocks. Rhizoliths are especially abundant, and at one locality the top of the cliff-forming sandstones supports wellpreserved stump and root casts of enormous trees (Bown, 1982, fig. 17D).

\section{BARITE SANDSTONE}

The Jebel Qatrani Formation is conveniently separated into upper and lower parts by a very persistent 4-10-m-thick white to pistachio green sandstone, here called the barite sandstone (figs. 18, 19, 23A, 27), that is developed about $152-162 \mathrm{~m}$ above the formation base. This unit persists from a point about $6 \mathrm{~km}$ northeast of Widan el Faras (where poor exposure and faulting prevent further tracing to the east) more than $60 \mathrm{~km}$ west and west-southwest to at least the area of Wadi Kadish. It is not present at Madwar el Bighal or farther southwest, and appears to be absent also at Elwaht Hialla. Nonetheless, it is an excellent marker bed throughout most of the study area, where it is the resistant unit upholding the El Ekhwat el Talata Escarpment, and is the cliff-forming unit making up the middle of the section at Tel Homar. The unit is locally absent across a subsurface anticlinal structural high some $25-32 \mathrm{~km}$ east of Wadi Kadish. The barite sandstone also appears to thin somewhat to the north, as evidenced in places where exposed in wadis cutting 

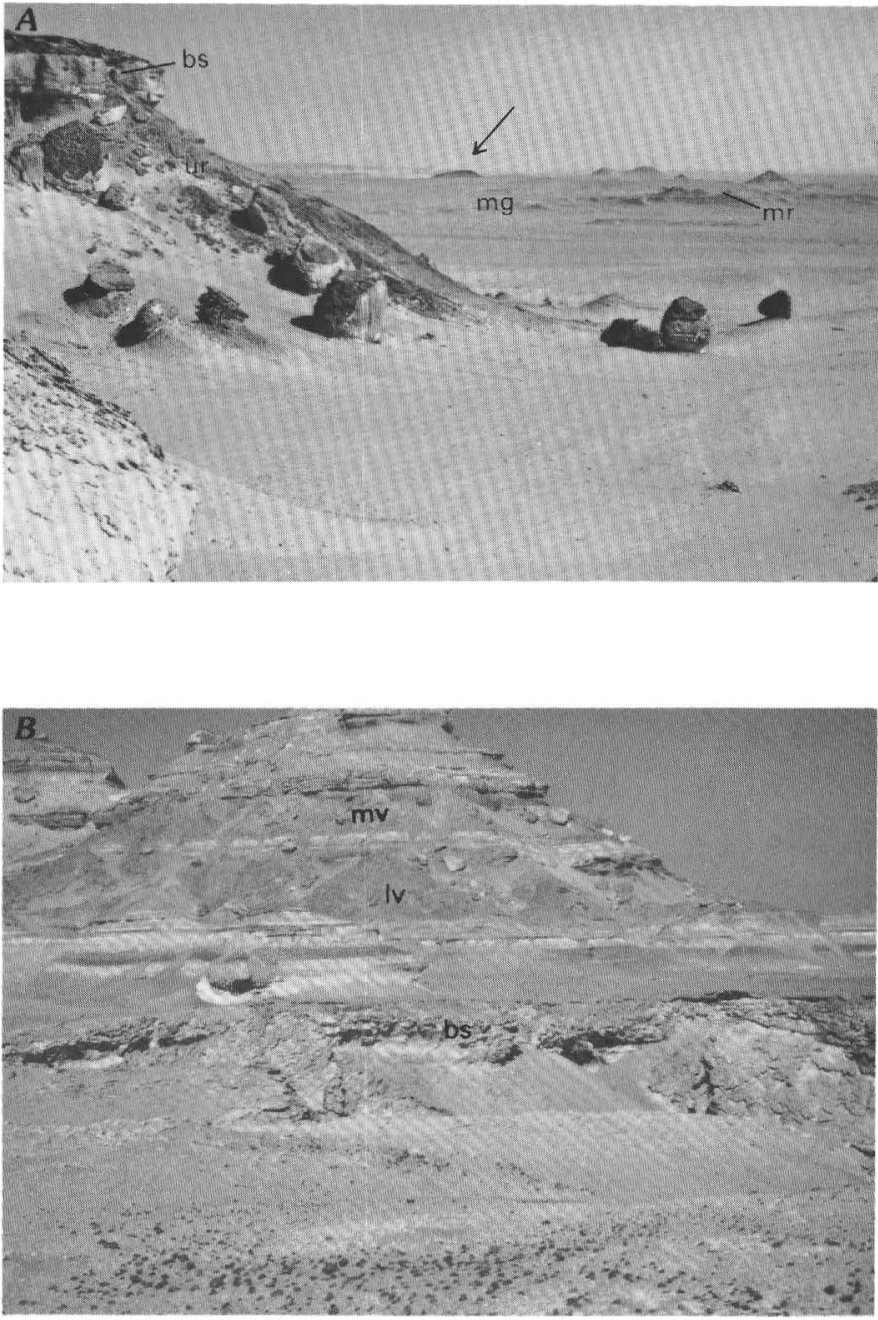

FiguRE 27.- Rocks of the upper part of the lower Jebel Qatrani Formation and the lower part of the upper Jebel Qatrani Formation. $A$, Exposures of the middle red sandstone sequence (mr), middle gravelly sandstone sequence $(\mathrm{mg})$, upper red sandstone sequence (ur), and barite sandstone (bs), about $0.9 \mathrm{~km}$ northwest of Tel el Eswid (arrow). This view is typical of exposures of the barite sandstone, a cliff-forming unit characterized by accumulation of lag blocks on the floors of the valleys beneath where it is exposed. $B$, Lower and middle variegated sequences (Iv and mv, respectively) of the upper part of the Jebel Qatrani Formation and the barite sandstone (bs) of the lower part of the formation, as exposed at the

deeply into the El Ekhwat el Talata Escarpment. The unit derives its name from barite $\left(\mathrm{BaSO}_{4}\right)$ nodules that are abundant in it at some localities.

The barite sandstone is cliff-forming and massive in appearance, and is composed of well-indurated green, white, and pinkish-white medium- to coarse-grained and locally granular sand. Chert pebbles, mud intraclasts, and what appear to be weathered lapilli tuff clasts are locally common in the lower meter, where they form linear bands. Along the line of section, the unit grades upward into a green, fine- to medium-

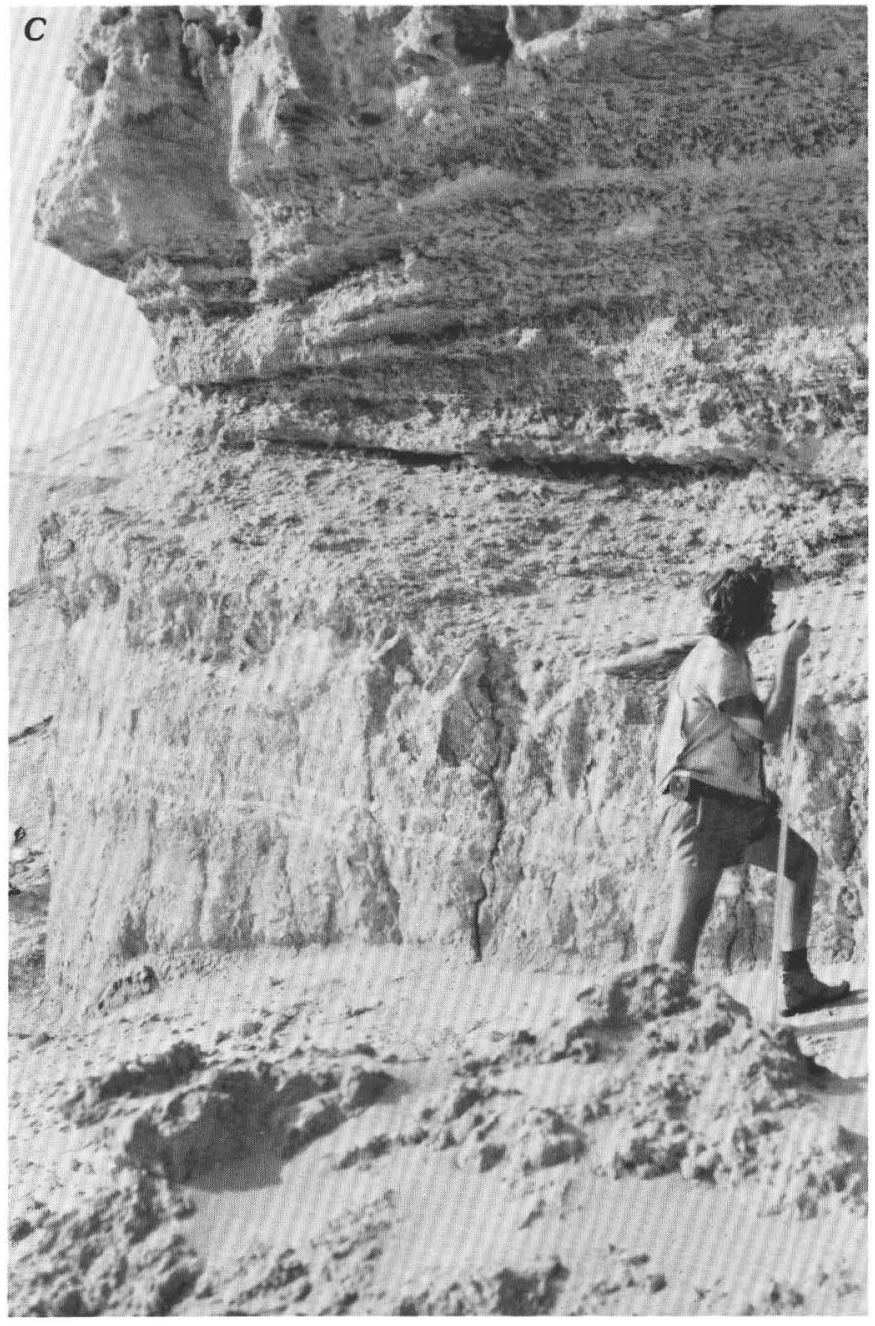

southwest margin of El Ekhwat el Talata. The lower and middle variegated sequences are principally floodplain sequences containing numerous superposed paleosols and are separated by the conspicuous light-colored band about halfway up the large butte in the backgound. Butte is approximately $45 \mathrm{~m}$ high. $C$, Contact (at level of man's shoulders) between upper red sandstone sequence (below) and the barite sandstone (above), about $1 \mathrm{~km}$ north-northeast of Tel Akgrab. At this locality, the upper part of the upper red sandstone is a clay-rich ultisol developed on sandy mudstone. Note the innumerable rhizoliths in the lower $3 \mathrm{~m}$ of the barite sandstone.

grained sandstone that is well cemented with calcium carbonate. The unit contains numerous rhizoliths at some localities (fig. 27C) and tends to weather in a distinctive "honeycomb" pattern. Internal stratification appears to consist of poorly preserved large-scale trough crossbeds. The middle $2.5 \mathrm{~m}$ is generally yellow, friable, medium sandstone that contains abundant gypsum nodules and finely disseminated granular gypsum. The uppermost part of the unit is composed of green to brown ledge-forming sandstone that is also highly gypsiferous locally. 


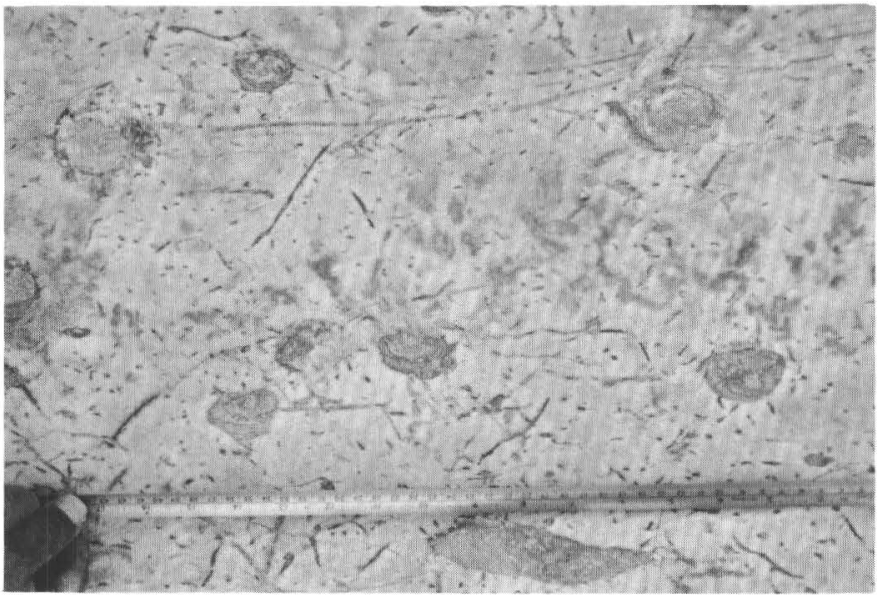

FiguRE 28.- Natural cross section of small termitaria and gallery systems of a subterranean termite in fine to medium sand of middle variegated sequence in the upper part of the Jebel Qatrani Formation, about $3.5 \mathrm{~km}$ southwest of Tel Beadnell. Top of tape is subdivided into centimeters, bottom into inches.

The barite sandstone appears to be a multistory unit; that is, it is made up of several coalesced broadly lenticular units that are separated by marked erosion surfaces. The bottom contact is irregular, with up to $6 \mathrm{~m}$ of regional relief. Along the line of section and for about $1 \mathrm{~km}$ to the east, the barite sandstone lies atop the upper red sandstone sequence; however, farther east and at some localities west of the line of section, the unit overlies deep fragipan horizons of ultisols that formed on sandy mudstones.

A characteristic feature of the barite sandstone is its unusually high gypsum content. This mineral variously takes the form of finely disseminated grains, balllike concretions, or smooth nodules, and in some places occupies about 80 percent of the volume of the unit. Where it is particularly abundant, the gypsum occurs as a series of closely spaced balls with diffuse contacts, tending to merge with one another. Laterally, the gypsum content of the barite sandstone varies considerably, and sections rich in the mineral adjoin sections a few hundred meters away that contain no gypsum. This relationship is clearly seen in the large north-southaligned wadi north of Tel Akgrab (fig. $1 C$ ); there, the southernmost exposures contain little or no gypsum but, moving northward, gypsum content increases from the top of the unit downward until the mineral makes up about 80 percent of the upper $8 \mathrm{~m}$. At two localities, barium has replaced calcium to form barite nodules in this unit (see later section on "Gypsum").

The barite sandstone is also noteworthy because weathered surfaces at its top locally yield large collections of fossil compound fruits of the liane Epipremnum (Wing and Tiffney, 1982; also in Bown and others,

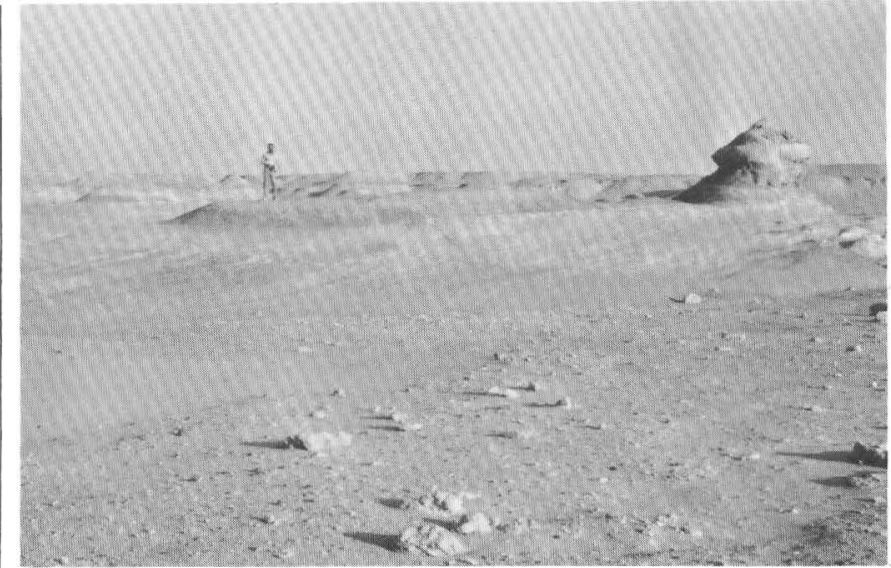

FIGURE 29.- South-dipping epsilon cross stratification overlain by floodplain mudstones near base of lower variegated sequence of upper part of the Jebel Qatrani Formation, about $1.2 \mathrm{~km}$ north of Tel Akgrab.

1982). At some of these sites, it seems likely that the fossil fruits are a lag concentration formed by deflation of younger beds; elsewhere they appear to be more clearly derived from the top of the barite sandstone itself. Fossil nests of subterranean termites (Termitichnus; Bown, 1982) occur in abundance in the middle and upper parts of the barite sandstone in some areas. On the east side of the large wadi north of Tel Akgrab, a lag accumulation of several hundred of these structures is developed on top of the barite sandstone where deflation has stripped off less resistant sediment.

\section{UPPER SEQUENCE OF \\ JEBEL QATRANI FORMATION}

In stratigraphic arrangement, the upper part of the Jebel Qatrani Formation in its type area and adjacent rocks are separable as shown in figure 19.

The lower and middle variegated sequences of the upper part of the Jebel Qatrani Formation (figs. 19, $27 B$ ) consist of $73 \mathrm{~m}$ of fine to coarse variegated sandstones, muddy sandstone and sandy mudstone, lenticular gravelly sandstones, and minor amounts of drab shale and sandy limestone. For much of this part of the section, bioturbation (fig. 28) and soil formation (paleosols) have obscured stratification. Where this is observable, sandstones and gravelly sandstones are typified by large-scale trough and tabular cross stratification. Grain size decreases upward within a coset from coarse sand to fine sand or muddy sand and, in some areas, small-scale trough cross stratification is developed above the large-scale sets. Well-developed epsilon cross stratification (fig. 29) is preserved in some parts of the lower variegated sequence. Basal contacts 
of most of the sandy units appear to be gradational with the exception of a few lenticular gravelly sandstones which have shallowly erosional lower contacts. Most of the sandstones are friable, but pervasive cementation by calcium carbonate or dolomite is commonly encountered at the bases of sandy units, especially where these overlie mudstones or limestones. The lower and middle variegated sequences are definable over most of the bench at the top of the El Ekhwat el Talata Escarpment, but individual units, though well expressed locally, generally do not persist for more than a kilometer. Aside from one unit, which shows consistent paleocurrent bearings between $352^{\circ}$ and $12^{\circ}$, most of the sandstones of the lower variegated sequence were deposited by streams flowing to the west-northwest or west $\left(260^{\circ}-330^{\circ}\right)$. In contrast, the middle variegated sequence has paleocurrent indicators showing that flow was principally to the southwest $\left(227^{\circ}-241^{\circ}\right)$. In the area $2-30 \mathrm{~km}$ east of Wadi Kadish, paleocurrent azimuths in the lower and middle variegated sequences vary from $220^{\circ}$ to $259^{\circ}$, with less numerous but persistent readings of $45^{\circ}-58^{\circ}$, suggesting possible tidal influence.

The lower and middle variegated sequences are host rocks both to important fossil vertebrate localities (notably $\mathrm{V}, \mathrm{G}, \mathrm{R}, \mathrm{Q}$, and 12 ; the locations of all fossil vertebrate localities are depicted in fig. 19) and to significant ichnofossil concentrations, particularly those of the termites. In addition, rhizoliths are spectacularly preserved in the carbonate cemented portions of some of the sandstones.

The top of the lower variegated sequence is formed by a laterally persistent unit of drab mudstone, muddy sandstone, and shale that is exposed continuously from Widan el Faras to Tel Homar (fig. 19). At two sites, the first about $1 \mathrm{~km}$ south-southeast of Widan el Faras and the second about $1 \mathrm{~km}$ north of Tel Taleb, this unit is made up of 2-10 $\mathrm{m}$ of drab mudstone, green and gray shale, and black carbonaceous shale. Though this unit is tabular in appearance, it locally consists of numerous lenticular packages of fine- to medium-grained sandstone that fine upward to sandy mudstone. The base of each fining-upward sequence is a scour defined by flaggy zones of brown iron oxyhydrate cemented sand and sand and mud intraclasts. Poorly preserved fossil wood and iron-silica petrifactions of at least 25 different kinds of fossil fruits (S.L. Wing, written commun., 1984) occur in this unit at the first locality (southsoutheast of Widan el Faras), where they are associated with large mammal bones. At both localities, carbonaceous shales in this unit yield abundant, wellpreserved leaf fossils (Wing and Tiffney, 1982).

Overlying the middle variegated sequence between Widan el Faras and Naqb el Garw are several broad lentils of gravelly sandstone that both intertongue with variegated sand and sandy muds developed beneath and lateral to them, and lie in broad, shallow, erosional scours developed on the variegated beds. Together, these lentils make up the sheet gravel sequence, consisting of about $31 \mathrm{~m}$ of white and yellow medium- to coarse-grained friable sandstone with lenses and interbeds of mud and sand intraclasts, chert pebbles and granules, and granular quartz sandstone. These beds are very distinctive because their surfaces are strewn with chert pebbles. West of Tel Beadnell, the sheet gravel sequence intertongues with red and orange sandstones and sandy mudstones that resemble those of the middle variegated sequence. East of Tel Beadnell, the sheet gravel sequence contains fewer and thinner interbeds of variegated sandstone and sandy mudstone and develops more of a multistory character.

Internal stratification is dominated by grouped sets of large-scale trough and tabular cross stratification. Maximum set thickness is about $1 \mathrm{~m}$ but decreases upward within cosets, as does grain size, which varies from coarse sand and fine gravel to medium sand. The thinner and finer sets commonly grade upward into massive-appearing medium sandstone. Well-preserved cross-stratified sets indicate paleoflow directions to the southwest, west, and northwest. At many localities, internal stratification is obliterated by plant and animal bioturbation.

The sheet gravel sequence of the upper part of the Jebel Qatrani Formation is reminiscent of the gravelly sandstones of the lower part of the formation, but differs from them in its lesser degree of interconnectedness. That is, individual channels filled with gravelly sandstone are enclosed in finer sediment, and it is only in a few areas (e.g., between Tel Beadnell and Widan el Faras) that the sequence develops a true multistory character. Also, in contrast to the gravelly sands developed lower in the section, the sheet gravel sequence contains little fossil wood and almost no well-preserved fossil logs, a characteristic of the upper part of the Jebel Qatrani Formation in general. The sheet gravel sequence is significant in that five of the seven most important fossil vertebrate localities in the upper part of the Jebel Qatrani Formation occur within it (quarries $\mathrm{I}, \mathrm{J}, \mathrm{M}, \mathrm{O}$, and $\mathrm{P}$ on fig. 19). It was also host to a diverse assemblage of trace fossils, including a variety of rhizoliths and traces of subterranean termites, crabs, and crayfish (Bown, 1982).

The uppermost part of the Jebel Qatrani Formation is made up of about $76 \mathrm{~m}$ of green, gray, red, yellow, and brown sheet sandstones and red and orange sandy mudstones. This is the upper variegated sequence and it contains by far the greatest proportion (about 15 percent) of mudstones found in the Jebel 
Qatrani section. Though dominated by fine- to medium-grained sandstone, the upper variegated sequence has great variability in lithology and bed geometry; it consists of large and small medium- to coarse-grained lenticular sandstones, thin, fine- to medium-grained sheet sandstones, lenticular mudstones, and tabular sandy carbonates. The lenticular geometries of most of these units reflect scour and crosscutting relations with underlying rocks.

Lenticular sandstones in the upper variegated sequence vary from 1 to $10 \mathrm{~m}$ in thickness and from about $50 \mathrm{~m}$ to more than $1 \mathrm{~km}$ in breadth, and texturally from medium sand to gravel. In general, the smaller troughs contain a greater proportion of gravelly sediment, whereas coarse sand is usually restricted to the bases of the larger channels or to the bases of fining-upward sequences developed in cross sets within them. Internal stratification in the larger channels also contains a significant proportion of large-scale tabular crossbedding. Distinctive, broad lenticular sandstone bodies varying from about 1 to $6 \mathrm{~m}$ in thickness and extending up to a few kilometers laterally are characteristics of the lower part of the upper variegated sequence. These units are generally composed of coarse to mediumcoarse orange or green sand and present a massive, almost sculpted appearance. They commonly contain lumpy, nodular to pipelike mottled areas that are green in orange sandstones and orange in green sandstones.

Lenticular sandstone bodies in the lower 22-32 m of the upper variegated sequence at Tel Beadnell resemble the apron-channel sandstones described by Bown (1979; = "ribbon" sandstones of Friend and others, 1979), in that thin, fine sandstone "apron strings" (="wings" of Bersier, 1958) extend laterally from the upper part of the central scour for several hundred meters. Lateral to these sandstones and intertonguing with them are thin, steeply dipping beds of alternating fine sandstone, sandy mudstone, and mudstone, all probably representing lateral accretion deposits.

A persistent medium- to coarse-grained sandstone is developed over a wide area at or near the top of the formation, where it has not been removed by erosion at the formation's unconformable upper contact. This unit is made up of large-scale planar tabular cross stratified and very large scale trough cross-stratified beds (developed in broad sets 3 to $7 \mathrm{~m}$ wide); paleocurrent indicators show that flow directions varied between $270^{\circ}$ and $315^{\circ}$ (west to northwest). This unit is everywhere intensely bioturbated and strongly cemented with calcium carbonate. The bioturbation has caused the surface of the sandstone to have a marbly texture composed of innumerable sandstone balls, and sand crystals are developed in these structures at several localities. Where this sandstone is preserved beneath the Widan el Faras Basalt, it has been reddened by scorching and oxidation of iron minerals. West of Tel Beadnell, this unit intertongues with a thick sequence of red muddy sandstone and red mudstone.

Two buff sandy carbonate beds occur in the upper variegated sequence of the Jebel Qatrani Formation. These are tabular units about 0.5 to $1.0 \mathrm{~m}$ in thickness, and they contain grains of fine to medium quartz sand (about 5 percent) suspended in micritic limestone or dolomite. These units are generally underlain by mudstone or muddy sandstone, are overlain by sandstone, and appear to have gradational lower and upper contacts. Freshwater charophytes and ostracodes and fish bones and scales are rare fossils in these units.

Beadnell (1905, p. 60) and Bowen and Vondra (1974, p. 130) recorded the presence of marine mollusks at two different localities in the uppermost Jebel Qatrani Formation near Widan el Faras. Because of the potential significance of these discoveries to interpretations of paleoenvironments in later Jebel Qatrani time, both localities were relocated and examined by us during the 1983 field season. Beadnell's mollusks came from a coarse, white, concretionary quartz sandstone developed in the lower $3-5 \mathrm{~m}$ of a $15-20$-m-thick medium to coarse green quartz sandstone about $50 \mathrm{~m}$ beneath the local base of the Widan el Faras Basalt. The locality, high on the south wall of a steep wadi $1 \mathrm{~km}$ north of Widan el Faras, yields complete internal molds and fragments of shells of a variety of marine mollusks, all of which are currently under study (D. Wilson, oral commun., 1984). The fossils are so numerous at this locality that it is clear that, in spite of their relatively poor preservation, the mollusks cannot have been transported very far after death. The unit containing these fossils forms a distinctive, steep, and cliffforming green band near the top of the upper Qatrani escarpment (fig. 30), and the unit was traced about $4 \mathrm{~km}$ westward, where another accumulation of the mollusks was found at a site about $30 \mathrm{~m}$ beneath the Widan el Faras Basalt. In addition to the invertebrate fossils, this locality also yields abundant trace fossils, including examples of a large Ophiomorpha (fig. 31A) and essentially horizontal sigmoid crab burrows otherwise seen by us only in what are believed to be shallowwater marine rocks in the Qasr el Sagha Formation. Further reconnaissance of upper Jebel Qatrani rocks exposed in the area between the last locality and Tel Beadnell revealed several similar but thinner medium to coarse green sandstones containing Ophiomorpha in the upper $70 \mathrm{~m}$ of the formation. Additional examples of the horizontal sigmoid burrows were located in a medium to coarse gray sandstone about $32 \mathrm{~m}$ above the base of the upper variegated sequence, in the narrow saddle connecting Tel Beadnell with higher parts of the 


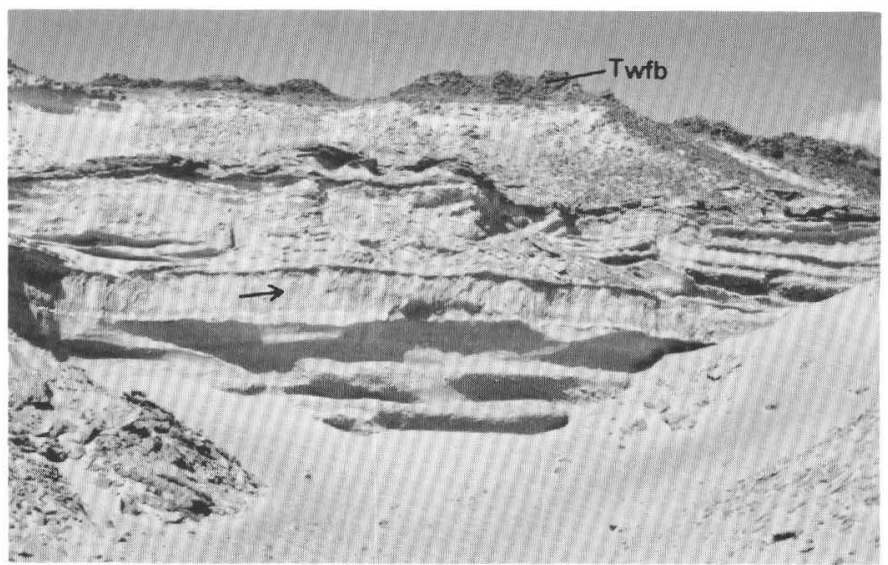

Figure 30.-Medium to coarse green sandstone (level of arrow) near top of upper variegated sequence of upper part of the Jebel Qatrani Formation. This unit is developed about $50 \mathrm{~m}$ beneath the base of the Widan el Faras Basalt (Twfb) and contains numerous concretions that yield a marine fauna dominated by mollusks. This unit and possibly those immediately above and below it were deposited during a brief, minor incursion of the Tethys Sea into the Fayum Basin. The marine sequence is overlain by fluvial sandstones and sandy mudstones containing paleosols.

upper Qatrani escarpment (fig. $1 C$ ). A last new locality with marine invertebrates was located about $4 \mathrm{~km}$ west of Widan el Faras and about $1 \mathrm{~km}$ southeast of the site that is $30 \mathrm{~m}$ beneath the Widan el Faras Basalt. There, several examples of a smaller Ophiomorpha (fig. $31 B$ ) are associated with a few poorly preserved internal molds of cerithid gastropods in outliers of a medium- to fine-grained green calcareous sandstone that is cut out laterally by scours in the upper part of the sheet gravel sequence. Physical stratigraphic relations indicate that this locality is about $80-90 \mathrm{~m}$ beneath the top of the formation, and it is the lowest known occurrence of marine-influenced sediments in the Jebel Qatrani Formation.

The locality cited by Bowen and Vondra (1974) occurs in a thin-bedded to laminated drab mudstone sequence high on the west tower of Widan el Faras. The invertebrate fossils occur as poorly preserved internal molds, shells, and shell fragments of mollusks, including the pelecypods cf. Eurytellina sp., cf. Plicatula sp., cf. Periploma sp., cf. Pitar or Callista sp., cf. Carditamera sp., and cf. Cardiidae, gen. indet., and the gastropod cf. Turbonella sp. (E.G. Kauffman, in Bowen and Vondra, 1974, p. 130). Most of the shells appear to have been transported prior to fossilization and the host sediment appears to have accumulated gradually in a shallow scour.

The four units making up the upper part of the Jebel Qatrani Formation (fig. 19) are loosely defined sequences that are characterized by heterogeneous lithologies, crosscutting relationships, and intertongu- ing of relatively coarser channel and near-channel sediments with relatively finer floodplain alluvium. Within the area adjacent to the lines of section, these rocks are conveniently separated for broad purposes of stratigraphic correlation by the drab/carbonaceous unit and by the conglomeratic sandstone sequence. West of Tel Beadnell, this fourfold division cannot be recognized owing to loss of the drab/carbonaceous unit and to thinning and eventual pinching out of the gravelly sandstone sequence between that landmark and Naqb el Garw (figs. 1, 2B, 2C). West of Naqb el Garw, the Jebel Qatrani cliffs are steep, the upper bench is narrower, much of the upper part of the formation was removed by erosion prior to deposition of the Widan el Faras Basalt, and stratigraphic relations are rendered unclear in many areas by extensive dune sand and serir cover. An undetermined thickness of upper Jebel Qatrani rocks exists above the barite sandstone in the upper valley of Wadi Kadish, where it is made up of alternating carbonate-cemented and uncemented, medium to coarse, gray, green, and yellow sandstones and red, orange, and green mudstones. Thick (up to $15 \mathrm{~m}$ ) masses of rhizoliths, including those of mangroves (Bown, 1982, fig. 16C, D), are distinctively developed over wide areas in the upper Jebel Qatrani Formation in and north of the Sarab Mukhafet. About $10 \mathrm{~km}$ east of Wadi Kadish, current azimuths of $210^{\circ}-$ $224^{\circ}$ and $26^{\circ}-48^{\circ}$ on uppermost Jebel Qatrani rocks indicate tidal influence on southwest-flowing streams. Between 25 and $32 \mathrm{~km}$ east of Wadi Kadish, the whole of the upper Jebel Qatrani Formation is less than $50 \mathrm{~m}$ thick across the axis of an anticline with slight surface expression and which trends about $257^{\circ}$. No rocks west of the Fayum Depression or to the east at Elwaht Hialla are known to belong to the upper part of the Jebel Qatrani Formation.

\section{CHEMICAL LITHOLOGIES IN THE JEBEL QATRANI FORMATION}

At some localities, a significant proportion of Jebel Qatrani lithology is composed of nonclastic rocks, especially gypsum, carbonates, silicates (flint), and ironstone. Though petrographic studies have not yet been undertaken to determine the origins of any of these rocks, all except the thin-bedded limestones are believed to be early diagenetic in origin. Taken together, these lithologies are volumetrically important and some discussion of their occurrence, relationships, and possible modes of origin is appropriate here.

\section{GYPSUM}

Fine granular gypsum is a common constituent of many mudstones and some sandstones in the Jebel Qatrani Formation. In mudstones it occurs as crystals 

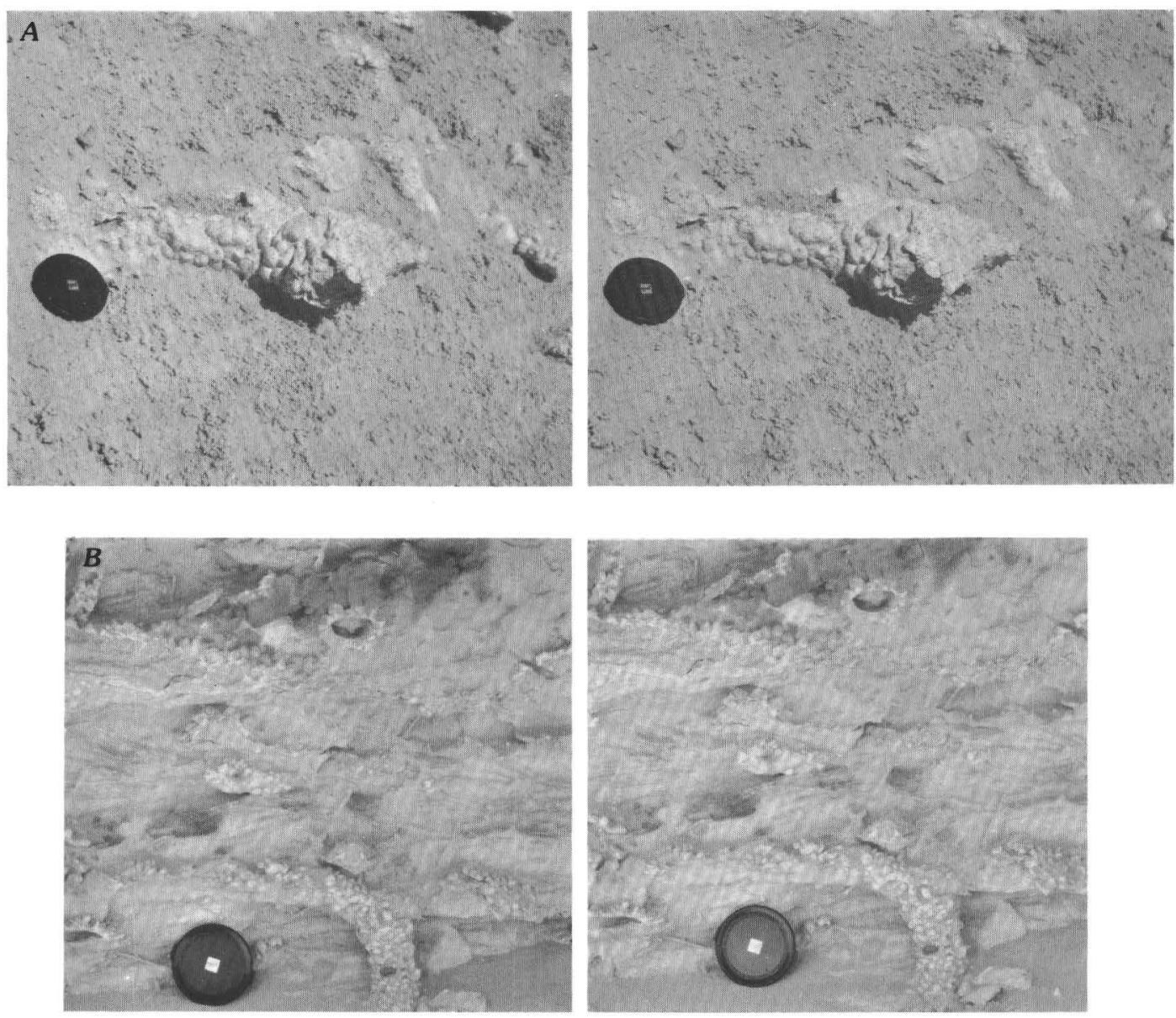

FiguRE 31.-Specimens of the trace fossil Ophiomorpha in the upper part of the Jebel Qatrani Formation. A, Stereophotograph of a large specimen of Ophiomorpha sp. weathering from medium to coarse sandstone about $30 \mathrm{~m}$ beneath base of Widan el Faras Basalt, in

or satin spar veinlets and is most abundant in drab sequences in association with carbonaceous shale (as in the carbonaceous shale at the top of the lower variegated sequence of the upper Jebel Qatrani Formation). In sandstones, gypsum variously occurs as local patches of finely disseminated crystals but in two instances, at the top of the lower green sandstone sequence and within the barite sandstone, it locally makes up much of the volumes of these sand bodies.

The upper part of the lower green sandstone sequence contains and (or) is overlain by as much as $15 \mathrm{~m}$ of massive gypsum developed as granules, gypsiferous sandstone concretions, and anastomosed veins of satin spar where it underlies drab or green muddy sandstones developed in the lower part of the middle red sandstone sequence, about $4.5 \mathrm{~km}$ northwest of Qasr el Sagha Temple (fig. $25 B$ ). This drab part of the middle red sandstone sequence is locally rich in plant debris, which occurs as a hash of poorly preserved stem and

upper variegated sequence, about $3.1 \mathrm{~km}$ north of Tel Comfessa. $B$, Stereophotograph of small specimens of Ophiomorpha weathering from a medium to fine green sandstone near the top of the sheet gravel sequence, about $2.0 \mathrm{~km}$ north-northeast of Tel Comfessa.

leaf fragments and carbonaceous flecks. Similarly, occurrences of masses of gypsum in the top of the barite sandstone appear to correlate in a general way with carbonaceous material in the drab green mudstone and carbonaceous mudstone and shale that is present about 9-25 $\mathrm{m}$ above and that separates the lower and middle variegated sequences of the upper part of the Jebel Qatrani Formation. Although the intervening rocks are generally more or less oxidized horizons of paleosols, we believe the stratigraphic relations of gypsum and carbonaceous matter indicate a causal correlation. We think it likely that sulfate in the ground-water system locally replaced carbonate in lime cement in the lower green sandstone sequence and the barite sandstone and that the source of the sulfur was decaying plant material in overlying sediments. The large amounts of gypsum in the underlying Qasr el Sagha Formation might likewise be due to the prevalence of shelly beds, the presence of organic-rich conglomeratic 


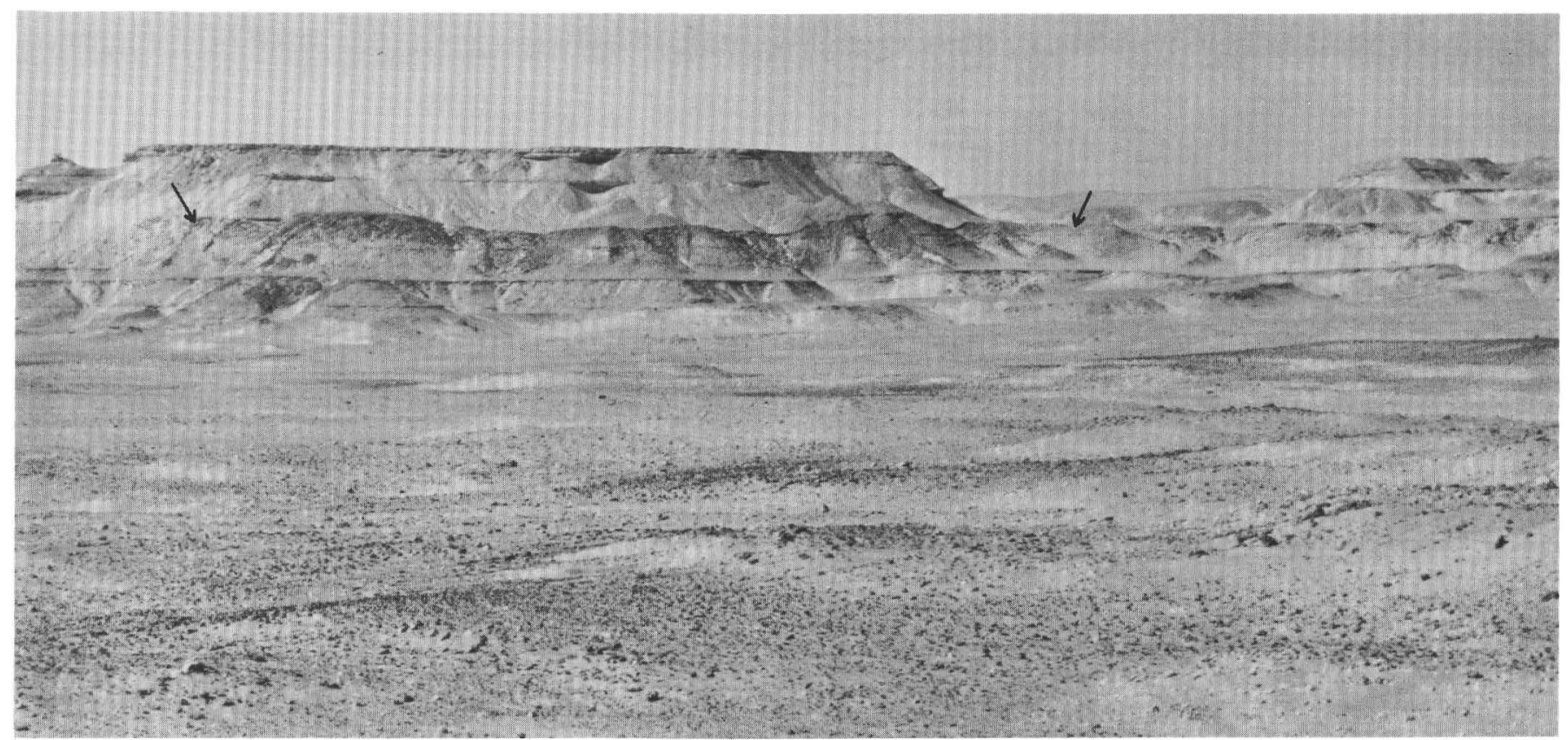

FIGURE 32.-Zone of calcium-carbonate-cemented sandstone at base of scour into less permeable rocks (delimited by arrows) on southeast side of Tel Beradt-shay, middle variegated sequence of the upper Jebel Qatrani Formation. Tel Beradt-shay rises about $30 \mathrm{~m}$ above the surrounding desert valley floor. View to northwest.

coquinas, and the high incidence of organic/carbonaceous matter in general; all are excellent sources of sulfur.

CarboNates aNd FliNT

In the Jebel Qatrani Formation, carbonates (both calcite and dolomite) occur as cement and as dense, thin-bedded, laterally persistent tabular beds. An early diagenetic origin is suggested for the cement, whereas charophytes, ostracodes, and fish remains found in the bedded carbonates indicate their primary origin.

Carbonate cement is sporadically developed in nearly all sandstone bodies of the Jebel Qatrani Formation, but it is nearly always discontinuous or is confined to the bases of sandstones or to the relatively coarse lower parts of cross-stratified cosets. The replacement and surrounding of ancient roots of plants by calcium carbonate, forming rhizocretions and root casts and tubules (Bown, 1982), indicates that its accumulation was very early diagenetic. We believe that it was related to mobilization and concentration of this mineral during ancient (Oligocene) soil formation.

The bases of Jebel Qatrani sandstones are commonly cemented, whereas the remainder of these units is generally relatively free of cement. Cemented lower portions of sandstones are the rule where the coarser lower portions of sandstones lie in scours cut in finer grained sandstones, muddy sandstones, or mudstones. We believe that this preferential distribution of cement reflects its concentration at contacts between relatively impermeable and relatively permeable sediment. Ground water moving through the coarse sand in ancient times introduced carbonates in solution which were then concentrated and precipitated there because the carbonate-enriched solution was perched above the underlying impervious unit (e.g., Brammer, 1968). This explanation is reinforced by cementation patterns in sediments at and near the contact of a broad, shallow scour surface on the south slope of Tel Beradt-shay (fig. $2 E$ ). There, a thick sandstone overlies an irregular paleotopography developed on a red sandy mudstone (fig. 32). Everywhere along this scour surface, on high and low points alike, calcium-carbonate cement is confined to the lower meter or so of the overlying sandstone. This relationship is quite similar to soil accumulations of other labile materials, in which the depth of accumulation is commonly related to the slope of the surface and the greatest concentration occurs at the contact with an impermeable zone, often a clay-rich "pan."

Early diagenetic movement of calcium carbonate in solution through the main bodies of sandstones throughout the Jebel Qatrani section is also evidenced by the preferred calcium-carbonate cementation of trace fossils in what are otherwise friable, unconsoli- 
dated sandstones. Concentration of carbonate was probably instigated by reducing conditions produced by relict organic material in these structures (Bown, 1982). In the Sarab Mukhafet and at Madwar el Bighal, Jebel Qatrani sandstones are more pervasively cemented than elsewhere in the Fayum Depression and thick mats of rhizoliths of mangroves and other plants dominate parts of the section. A primary source of much of the calcite cement in those areas was probably algae, organisms that aid in concentrating calcite in coastal mangrove marshes and backswamps (Hardie, 1970).

Tabular, thin-bedded limestones and dolomitic limestones up to about $1.5 \mathrm{~m}$ thick and extending a few hundred meters to several kilometers laterally occur in the lower, middle, and upper variegated sequences of the upper part of the Jebel Qatrani Formation. These units vary laterally from relatively pure, dense, buff micrite with sparry calcite crystals lining vugs to sandy or muddy micritic limestones. Units with the least component of clastic materials sometimes contain ostracodes, charophyte gyrogonites, fish bones and scales and, more rarely, poorly preserved gastropod, crocodile, turtle, and mammal remains. Bowen and Vondra (1974) attributed most of these carbonates to caliche formation; however, the presence of freshwater ostracodes and charophytes, as well as a lack of requisite textural features in the carbonates, belies that origin (Bown and others, 1982). Instead, most evidence suggests that they are probably shallow floodplain pond deposits (R.M. Forester, written commun., 1981). This idea is reinforced by stratigraphic relations showing that at least some of the thin-bedded carbonates grade laterally into beds or nodular zones of iron oxyhydrate ironstones rich in rhizoliths.

At some localities, these tabular carbonate beds also contain flint nodules or bedded flint, or they grade laterally into thin, tabular flint beds. These units are quite distinctive and resistant and cap several of the prominent flat-topped hills in the area, including Tel Homar (fig. $2 C, D$ ), Tel Markgraf (fig. $2 D, E$ ), and Tel Comfessa (fig. $2 E$ ). The landscape in these and other areas around the El Ekhwat el Talata Escarpment is littered with whole and broken flint nodules which have lagged down during erosion of the surrounding rocks. The numerous pits dug into the flint beds on Tel Homar and Tel Comfessa show that these beds were extensively exploited for artifact materials in ancient times (Beadnell, 1905, p. 61; Caton-Thompson and Gardner, 1934). The origin of the silica is uncertain, though what appear to be weathered vitric tuff clasts are found in the base of the barite sandstone northeast of Tel el Eswid, and these and the basalt flows above the Jebel Qatrani Formation attest to periodic extrusive volcanic activity. Therefore, a possible source of the silica is devitrification of volcanic ash that was finely disseminated in the sediment.

IRONSTONE

Hydrated and dehydrated iron compounds are practically ubiquitous in the Jebel Qatrani Formation, and the differential stratigraphic distribution of this material in its various states gives the formation its colorbanded appearance. The coarser sandstones are generally white, yellow, or gray-green and may contain a few insignificant zones of red, orange, or brown mottling. The finer lithologies, on the other hand, are typically brightly colored in various shades of red, purple, orange, yellow, brown, green, and even blue. Most of this coloration as well as certain zones of iron- and (or) manganese-rich nodules formed by the translocation and concentration of iron, manganese, and aluminum compounds during ancient pedogenesis (see following section on "Paleosols"). Other concentrations are less clearly attributable to soil formation and are treated here.

Platy, reddish-brown ironstone litters the surface of the Jebel Qatrani Formation in many areas where it has lagged from the surrounding sediment. In places, the ironstone is seen in place as $1-10$-mm-thick laminae that mark cross-stratified set boundaries. As is the case with calcite, this appears to reflect concentration of the minerals at boundaries between relatively permeable and impermeable sediments. Brown and yellow-brown ironstone (limonite, goethite, and lepidocrocite) is also one of the principal materials that replaces mollusk shells, the roots of plants, and (sometimes in conjunction with silicate minerals) wood and fruits. At one locality, limonite pseudomorphs after gypsum are abundant, and even fish, crocodile, and mammal bones are occasionally found replaced by ironstone.

Distinctive features of some areas of the Jebel Qatrani landscape are isolated black hills, a few tens of meters long and wide and about 5-15 m high. These hills are composed of sand that has been permeated with hydrated iron minerals or with a combination of ironstone and silicates. The cementation renders them highly resistant to weathering and erosion, much more so than the surrounding largely unconsolidated sands. Examination of two of these masses that are not yet wholly isolated by erosion shows them to be lozenge shaped and to lie in scours in the surrounding sediment. Several of these hills lie in the lower part of the Jebel Qatrani Formation between Etnain Efreet and Tel Homar, and in another area between 3 and $8 \mathrm{~km}$ northeast of Widan el Faras. Much of one of these hills, Tel el Eswid (figs. $1 C, 27 A$ ), is made up of large ferruginized root tubules (fig. $33 A$ ). 


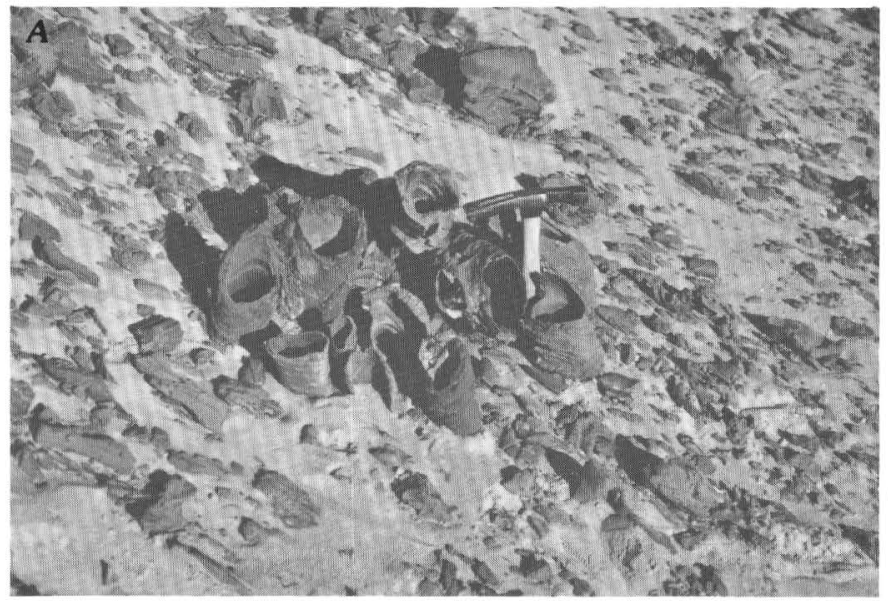

FiguRE 33.-Rhizoliths in ironstone, Jebel Qatrani Formation. A, Large root tubules in silicified ironstone in lower part of middle gravelly sandstone sequence in lower part of the Jebel Qatrani Formation at Tel el Eswid. Grouping is artificial. $B$, Iron-silicate root casts in pebbly coarse sandstone of upper part of middle varie-

An early diagenetic origin for most of this ironstone is indicated by its in situ replacement of plant roots (Alhonen and others, 1975; Bown, 1982, fig. 15D) and by the common occurrence of abraded ironstone clasts in the gravelly or granular parts of some of the sandstones. The lenticular geometries of these deposits and their positions in erosional scours suggest that they accumulated in low areas that filled gradually with sediment and maintained wet conditions, thus facilitating both the accumulation and decomposition of plant debris and the accumulation and hydration of iron compounds. This conclusion is reinforced by the recognition of lenticular scours filled by drab mudstone and muddy sandstone and containing innumerable ironstone-cemented rhizoliths (fig. 33B), associated with carbonaceous mudstone, coalified plant debris, and large amounts of platy ironstone.

\section{PALEOSOLS}

Nearly all sediments of the Jebel Qatrani Formation have, to a greater or lesser degree, undergone early diagenetic modifications related to ancient soil development. In fact, the Jebel Qatrani Formation is another sequence of numerous stacked paleosols like those in the alluvial lower Eocene Willwood Formation of Wyoming (Bown and Kraus, 1981), and we believe that the development of this type of sequence of superposed soils is to be expected in most ancient alluvial sequences (Kraus and Bown, 1982; in press).

The most striking evidence of paleosol formation in the Jebel Qatrani sequence is the brilliant variegation of the sediments, especially well marked in the muds

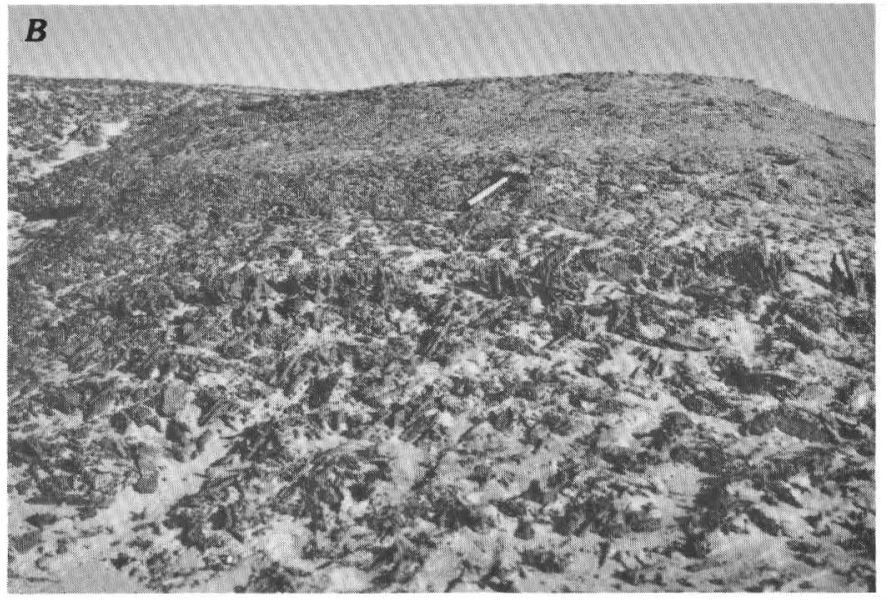

gated sequence of upper part of the Jebel Qatrani Formation, about $1.7 \mathrm{~km}$ north-northwest of Tel Homar. The casts are in growth position at two levels, the first at the head of the hammer, and the second, a better defined zone, below the hammer in the middle of the exposure.

and in the finer grained sands of the lower, middle, and upper variegated sequences of the upper part of the formation. Geochemical studies already accomplished show that this variegation reflects the redistribution of soluble iron compounds in ancient soils and their concentration in lower soil horizons by ground water. There they were hydrated, dehydrated, oxidized, or maintained in a reduced state depending on the thendominant chemical regimes of the soils. In places, the concentrations of iron and manganese are so great that nodular zones or flaggy plinthitic (duricrust) horizons occur. In other soils, lesser amounts of these labile minerals accumulated and then were partially removed by reducing water, causing the rocks to be mottled. In general, orange, yellow, and brown horizons in these ancient soils reflect wetter and (or) cooler conditions in which iron minerals were hydrated during oxidation. Red horizons developed in soils in which drier and (or) warmer conditions or better drainage permitted the formation of dehydrated iron compounds.

Color distribution is generally tabular and generally unrelated to lithology or internal stratification; however, close inspection of these tabular bands sometimes reveals fingers of pigment following internal stratification for a few centimeters. These probably resulted from increased permeability of coarser or poorly sorted sands. Laterally, most Jebel Qatrani soils persist for several kilometers, until they are no longer exposed or have been cut out by erosion. Others change gradually in color laterally (e.g., from red to red mottled with orange to orange) and reflect differential horizon development related to differing ground-water regimes on local topography (catenization), or pedofacies differences (Bown and Kraus, in press). 


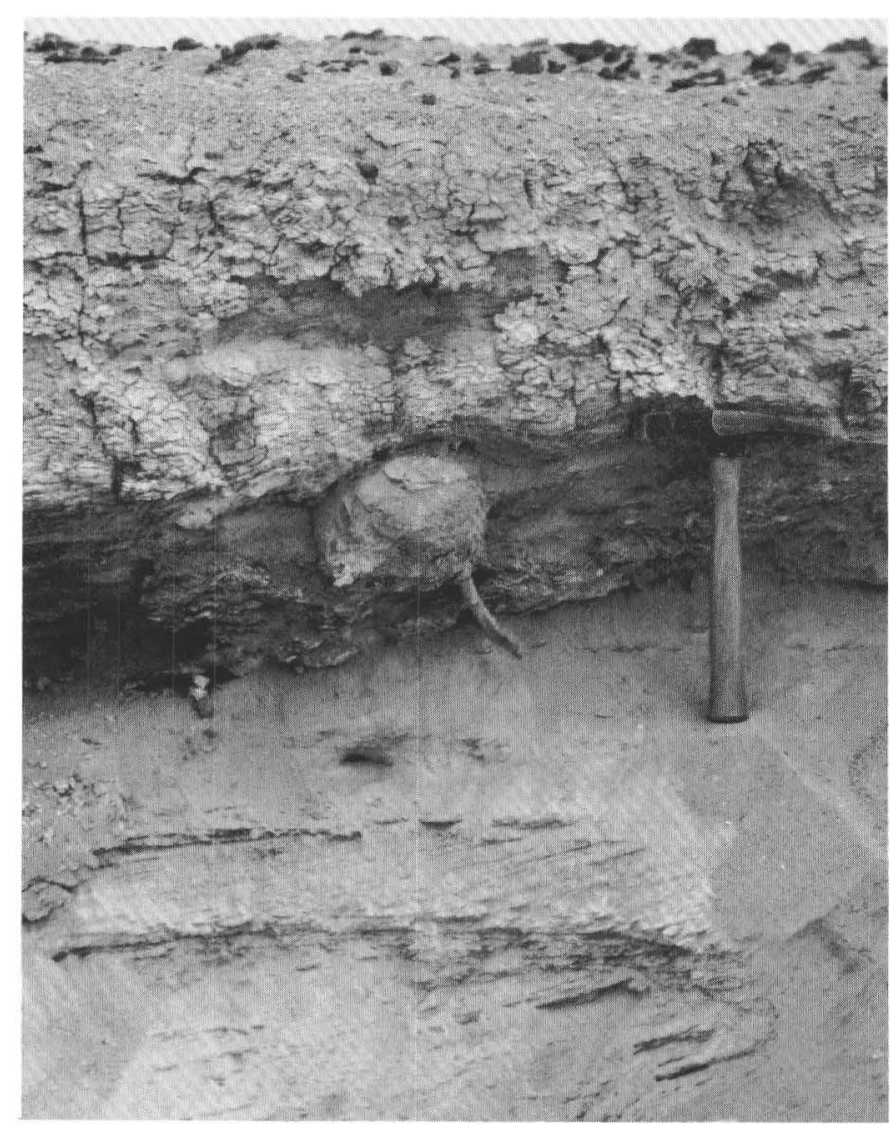

FiguRE 34.-Termitarium and entrance gallery of subterranean termite nest (type specimen of Termitichnus qatranii Bown, 1982) as preserved in muddy medium to fine sand immediately beneath green mudstone at base of drab carbonaceous unit separating lower and middle variegated sequences of upper part of the Jebel Qatrani Formation; about $0.9 \mathrm{~km}$ southeast of Widan el Faras.

Additional evidence of paleosols in the Jebel Qatrani Formation includes the presence of clay skins (cutans) on clastic grains and the presence of clay-lined vugs. Both phenomena result from the downward translocation of clays by soil water and their concentration in vacuities or on the surfaces of clastic grains. In some lower soil horizons (especially the fragipans; see below), the buildup of clay was so great that a thick, impervious pan formed that eventually prevented downward percolation of ground water. The clay pans became the site for concentration of iron minerals; consequently, these units are easily recognized in the field by their bright brick-red color.

Rhizoliths and trace fossils produced by sedimentsurface or near-surface organisms are excellent paleosol indicators, and the Jebel Qatrani Formation has the most diverse and best preserved assemblage of these fossils of any known alluvial deposit in the World (Bown, 1982). The rhizolith assemblage contains root and stem fossils of many small bushy plants, reedy

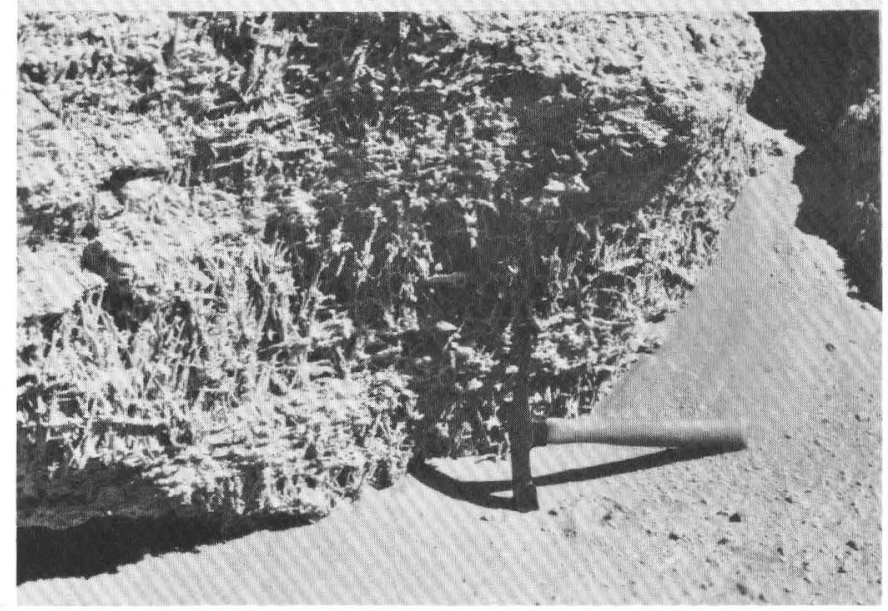

FIGURE 35.-Rhizoliths (root cast and root tubules) in inceptisol developed on medium sand in middle part of middle variegated sequence of upper part of the Jebel Qatrani Formation, about $0.6 \mathrm{~km}$ east of east butte of Tel Markgraf. As illustrated in this example, initial soil formation in the Jebel Qatrani Formation was commonly characterized by obliteration of primary stratification by bioturbation, accompanied by cementation of the lower horizons, in this instance with calcium carbonate. Though most primary stratification has been destroyed in this example, some sedimentary set boundaries are still preserved.

plants, and trees as well as traces of animals, including termites, ants, crabs, crayfish, oligochaete worms, bees, and vertebrates. Rhizolith masses are commonly found in the A horizons of the podzolic soils, and most of the nests of subterranean termites (fig. 34) appear to occur in the lower parts of the sola of a variety of poorly developed soils. Rhizoliths and animal bioturbation, however, are never found in paleosols with clay-rich (argillic) horizons.

Comprehensive studies of the structure, genesis, classification, and paleoenvironmental significance of the Jebel Qatrani paleosols are in progress; however, at this stage of study it appears that at least three major soil groups are represented: Inceptisols (moderately developed soils, including aquepts and tropepts), Spodosols (soils with a spodic horizon, including aquods and ferrods), and Ultisols (soils with a pronounced argillic horizon and low base content, including aquults and udults). The inceptisols (fig. 35) are the most widely developed group of Jebel Qatrani paleosols and reflect little more than incipient soil development. They are especially widespread in the coarser channel deposits, where they are marked with rhizolith or other trace fossil concentrations, local carbonate cementation, and yellow, brown, or orange coloration commonly developed only as mottled areas. Their poor development reflects sporadic erosional and depositional activity within the meander belt and the inability to build up significant concentrations of soil plasma minerals 
(labiles) owing to high permeability of the sediment, high ground water, and a relatively high degree of sediment reworking.

The spodosols are much better developed soils but in the Jebel Qatrani Formation they show varying stages of maturity. They are identified by their singularly good horizon differentiation (well-marked A and B horizons and intertonguing albic and spodic horizons) and by accumulation of iron and aluminum compounds in the lower A and upper B horizons (Bown, 1985). The spodic horizons are generally humus-poor (little organic carbon) and most spodic paleosols of the Jebel Qatrani Formation are therefore ferrods.

The ultisols (fig. 36) are very well represented in the Jebel Qatrani Formation, where some very mature varieties are developed. They are identified by their very pronounced clay-rich horizons (Bt, or textural horizons), which are developed on mostly sand or muddy sand parent materials. Most of these soils show some mottling and therefore probably are most closely related to the aquults.

Kraus (in Bown and others, 1982) identified fragipan horizons in some Jebel Qatrani soils. At that time, these soils were termed spodosols, but it now appears that all of the soils with fragipan horizons probably belong to the ultisols. Fragipan horizons are especially prevalent in the middle red sandstone sequence and at the top of the upper red sandstone sequence (lower part of Jebel Qatrani Formation), and in the lower, middle, and upper variegated sequences (upper part of Jebel Qatrani Formation). Fragipans are subsurface pedogenic horizons that appear indurated when dry but disintegrate when wet (see, e.g., Soil Survey Staff, 1975; Bridges, 1978). They are also typified by high bulk density, an upper zone leached of free iron, aluminum, manganese, and silicate clays, and a lower zone that is enriched in these constituents. The lower zone is commonly divided into polygons (fig. 36) by descending tongues of the upper eluviated zone. Root penetration is strongly restricted in fragipan horizons because of their great density and induration, enhanced by the high clay content. Fragipan horizons are very imperfectly known in modern soils and then from only a few widely separated soils of different character and different parent materials. Their genesis is problematical (Carlisle and others, 1957; Daniels and others, 1966). The fragipans of the Jebel Qatrani Formation vary in thickness from about 0.8 to $2.8 \mathrm{~m}$ and have polygons ranging in diameter from about $5 \mathrm{~cm}$ to nearly $2.0 \mathrm{~m}$ (fig. 36D). Though carbonate-cemented rhizoliths are abundant in the Jebel Qatrani Formation, none are known in any of the fragipan horizons. Some of the ultisols with fragipan horizons appear, from their high clay content, enormous polygons, and depth of hori- zonization, to be very mature or a relatively long time in forming. The most mature of these ultisols almost invariably lie beneath and (or) lateral to rather largescale multistory-multilateral sand bodies. These relations attest to the relocation of major Jebel Qatrani drainages onto very mature, very slowly aggrading, more distal portions of the flood basin.

The remarkable paleosol sequence of the Jebel Qatrani Formation has great potential for detailing soil conditions and general Oligocene climatic regimes in northern Egypt. However, the study of Tertiary and older paleosols is in its infancy, and the techniques for their study and evaluation are only now being formulated.

\section{WIDAN EL FARAS BASALT (UPPER OLIGOCENE)}

\section{DISTRIBUTION}

Everywhere in the Fayum Depression, the contact of the Jebel Qatrani Formation with overlying rocks is a pronounced erosional unconformity of unknown magnitude. At Widan el Faras erosional scour is minimal, about 1-3 m; however, the contact descends markedly to the west and to the south such that about $4 \mathrm{~km}$ west of Widan el Faras about $25 \mathrm{~m}$ of the upper part of the formation that is present at Widan el Faras is missing. The contact rises again west of this point, and it appears that nearly as much of the upper variegated sequence of the formation is preserved at Tel Beadnell (fig. $2 E$ ) as is present at Widan el Faras. At the north edge of the Fayum Depression, the Jebel Qatrani is

FIGURE 36.-Fragipan horizons in Jebel Qatrani paleosols. A, Ultisol with two fragipan horizons, each characterized by tongues of albic (white) material descending into the clay-enriched B horizon. Though the composite fragipan horizon is relatively thick, the soil appears to be more or less intermediate in maturity relative to other Jebel Qatrani fragipan soils because there is little good polygon development. Top of upper red sandstone sequence of lower part of Jebel Qatrani Formation, about $0.8 \mathrm{~km}$ north-northwest of Tel Taleb. B, Fragipan horizon (Bf) overlying clay-enriched textural horizon $(\mathrm{Bt})$ in ultisol developed on sandy mudstones in top of upper red sandstone sequence of lower part of the Jebel Qatrani Formation, about $2.0 \mathrm{~km}$ northeast of Tel el Eswid. Contact of ultisol with overlying barite sandstone is erosional. $C$, Fragipan horizon with well-developed small polygons in upper part of middle variegated sequence of the upper Jebel Qatrani Formation, about $8.0 \mathrm{~km}$ northwest of Tel Homar. $D$, Mature fragipan horizon with exceptionally large polygons (an example is between the two men) developed on sandy mudstones and muddy sandstones at top of upper red sandstone sequence of lower part of the Jebel Qatrani Formation, about $2.0 \mathrm{~km}$ south of Widan el Faras. $E$, Ultisol with thin fragipan horizon and small but well-developed polygons in top of middle red sandstone sequence of lower part of the Jebel Qatrani Formation, about $2.1 \mathrm{~km}$ east-southeast of Tel el Eswid. 

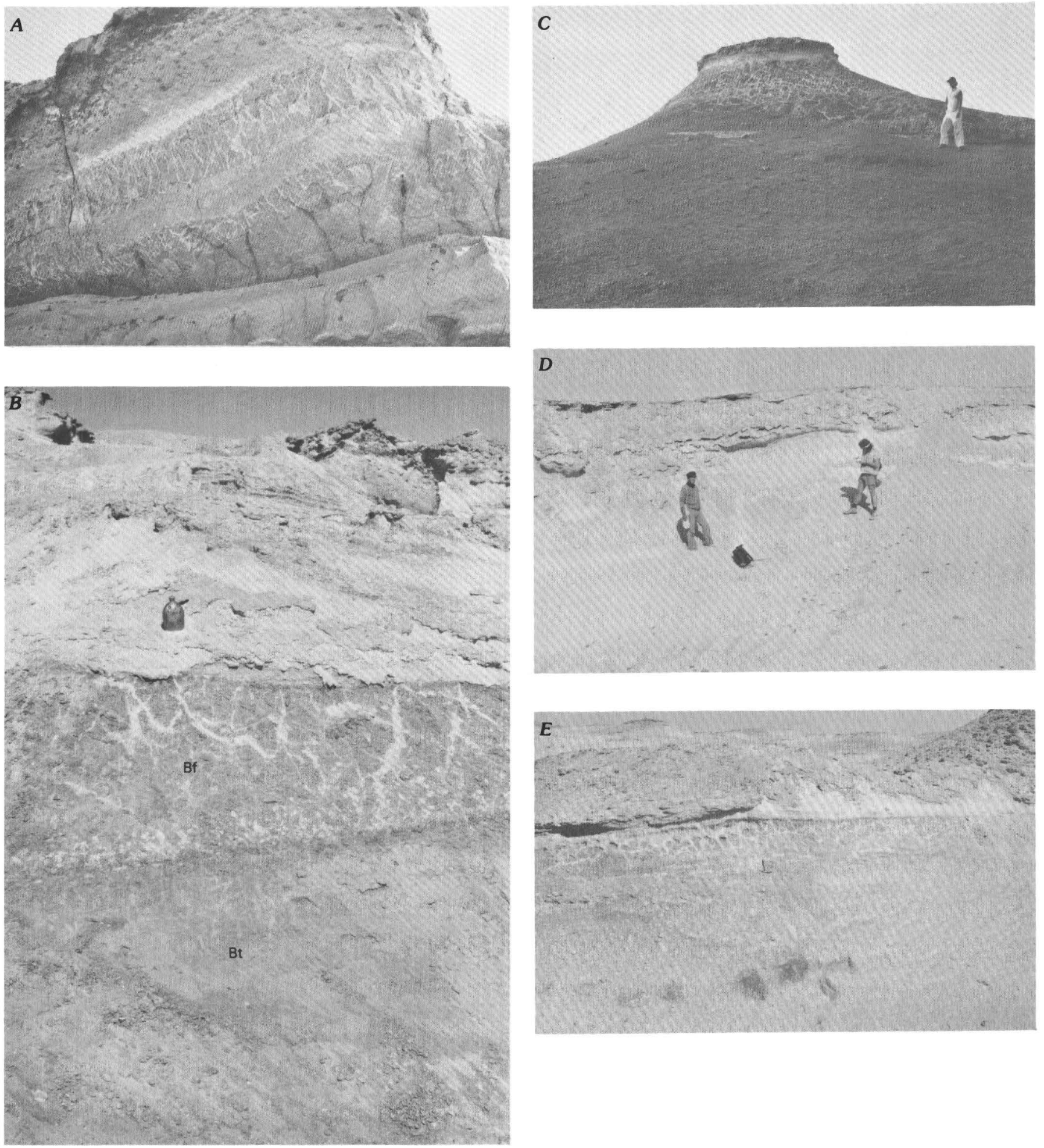


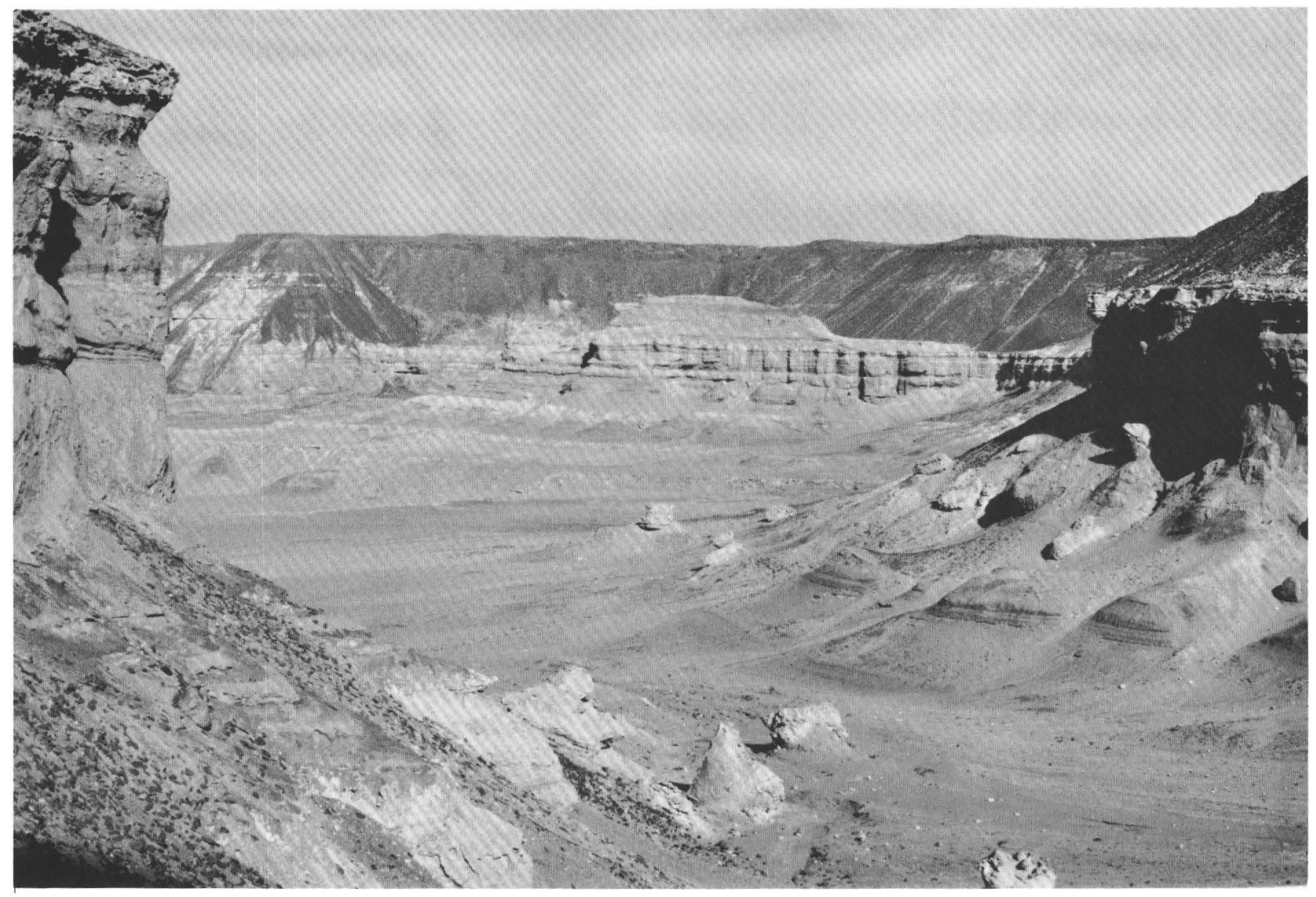

FIGURE 37.-Exposures of upper variegated sequence of upper part of the Jebel Qatrani Formation and of Widan el Faras Basalt (dark, ledge-forming unit on upper horizon in distance), as developed in the area from 0 to $2.0 \mathrm{~km}$ west-northwest of Widan el Faras.

capped by $2-25 \mathrm{~m}$ of the Widan el Faras Basalt (Bowen and Vondra, 1974; fig. 37, this paper), which is exposed from Elwaht Hialla on the east to Naqb el Garw on the west (figs. $1 B, 2 B$ ). Although highly variable in thickness owing to both number and thickness of original flows as well as topographic irregularities at its lower contact, the basalt forms a continuous sheet from Elwaht Hialla to the top of Jebel Qatrani north of Tel Homar. It appears to be thinnest (about $2-8 \mathrm{~m}$ ) at Elwaht Hialla, where it is also repeated several times in some areas by en echelon north side downthrown normal faults. It appears to be thickest (about $25 \mathrm{~m}$ ) above Tel Beadnell. West of Tel Homar, the Jebel Qatrani Formation is overlain by either local pods of this basalt or by the Miocene alluvial Kashab Formation. The Widan el Faras Basalt reaches thicknesses of $80-130 \mathrm{~m}$ in the subsurface north of the Jebel Qatrani (Bayoumi and Sabri, 1970).

Between Tel Homar and Naqb el Garw, local deep erosional scours mark the unconformity between the basalt and the Jebel Qatrani Formation and record a prebasalt topography of relatively steep hills and narrow valleys with at least $40 \mathrm{~m}$ of regional relief. During the first extrusion, the basaltic lava flowed down these valleys, filling the shallowest of them and capping the lowest hills. However, in areas of sharper relief, where the volume of basalt was inadequate to completely fill the deeper valleys, lenses of valley-fill basalt are discontinuous and laterally abut Jebel Qatrani rocks. In some areas, topographic inversion in the present-day arid climate has caused the major north-south-aligned wadis to originate at areas on the Jebel Qatrani between these lenticular basalt masses. These relations are best seen at the top of the Jebel Qatrani in the area between Tel Homar and Naqb el Garw (fig. $2 C$ ). As observed by Beadnell (1905, p. 61), the basalt terminates north of the western shore of Birket Qarun (at Naqb el Garw) and exists nowhere else in the Fayum Depression. It is probably present at Jebel Abu Roash west of Giza (Beadnell, 1902; see fig. 1B, this paper) 
and might have equivalents in the Eastern Desert of Egypt (Shukri and Akmal, 1953; Said, 1962).

\section{INTERNAL STRATIGRAPHY AND AGE}

The Widan el Faras Basalt is a dark, generally densely aphanitic iron-rich extrusive basalt. It appears to be composed of a single flow in areas where it is thinnest; however, weathered and sometimes scorched contacts within the basalt, as well as thin coarse sandstone interbeds (some containing mixed quartz sand and basaltic debris), attest to the presence of at least two or three separate flows over much of the area of exposure of the basalt. These shallow scours show that unconformities of unknown magnitude are contained in the Widan el Faras Basalt. The basalt's upper contact with the overlying Kashab Formation is also erosional and, in the area between Widan el Faras and Tel Homar, is marked by at least $9 \mathrm{~m}$ of relief.

Simons (in Simons and Wood, 1968) recorded K/Ar dates of $24.7 \pm 0.4$ and $27.0 \pm 3.0$ million years for two samples of the Widan el Faras Basalt collected at two unknown localities in the area between Tel Beadnell and Widan el Faras. A sample recovered in 1981 from $60 \mathrm{~cm}$ above the base of the topographically lowest flow about $2 \mathrm{~km}$ west-northwest of Widan el Faras was analyzed by J.D. Obradovich of the U.S. Geological Survey and yielded a date of $31.0 \pm 1.0$ million years (Fleagle and others, in press). This demonstrates that rocks of the Jebel Qatrani Formation immediately beneath the lowest basalt flow are at least as old as late early Oligocene (Tarling and Mitchell, 1976) or earliest late Oligocene (Berggren and others, 1978), and this is with no allowance for the time contained in the erosional unconformity that separates the basalt from the highest beds of the Jebel Qatrani Formation. The highest important fossil vertebrate localities lie another $90 \mathrm{~m}$ beneath this unconformity, so it is a pretty safe guess that the youngest part of the Fayum fauna is probably at least 32.5 million years old. It is almost certain that the two younger dates were obtained from exposures of younger flows. Thus, the youngest exposures of the Widan el Faras Basalt are older than the oldest Tertiary basalts in the Bahariya Oasis (Meneisy and el Kaliuobi, 1975). The geographically closest basalts of similar age to any capping the Jebel Qatrani occur at Abu Zaabal, near Cairo (23.2 $\pm 0.8 \mathrm{Ma}$; Meneisy and Kreuzer, 1974).

The uppermost Qasr el Sagha Formation and its lateral facies equivalent, the Ma'adi Formation, contain an abundant echinoderm and oyster fauna, including Anisaster gibberulus, Echinolampas crameri, Ostrea clotbeyi, $O$. reili, $O$. fraasi, Carolia placunoides, and Plicatula polymorpha. In Egypt, these forms have tra- ditionally marked the uppermost Eocene (Said, 1962), and these occurrences and the age of the lowest part of the Widan el Faras Basalt suggest that the overlying Jebel Qatrani Formation is largely of early Oligocene age. Nonetheless, the Jebel Qatrani Formation yields what appear to be largely endemic mammals and no taxa whose ranges are known to be diagnostic of the late Eocene or early Oligocene, much less a more constrained time framework within the early Oligocene. Though we believe it unlikely, it remains conceivable that an unknown part of the basal Jebel Qatrani Formation is actually latest Eocene in age, as was suggested by Savage and Russell (1983), among others.

\section{KASHAB FORMATION (MIOCENE)}

The Widan el Faras Basalt is overlain by the Miocene alluvial Kashab Formation at the top of the Jebel Qatrani (the Kashab is the same as the El Raml Member of the Moghra Formation of Omara and Sanad, 1975). The contact is markedly erosional, and scours in the top of the basalt are filled with coarse sand, sometimes containing basaltic debris, and chertpebble conglomerate. In the Jebel Qatrani area, a prominent chert-pebble and cobble conglomerate is nearly always found in the lower 10-12 $\mathrm{m}$ of the Kashab Formation. Weathering of this and of the other, rather common chert-pebble and cobble conglomerates in the Kashab has produced a desert pavement over much of the desert north of Jebel Qatrani, and extensive lags of chert-pebbles of Kashab origin occur on Jebel Qatrani and even Qasr el Sagha exposures to the south. In some places between Tel Beadnell and Naqb el Garw and everywhere west of Naqb el Garw, the Widan el Faras Basalt is absent and the Kashab Formation unconformably overlies the Jebel Qatrani Formation, although these units are lithologically quite similar and it is in many places difficult to locate the contact with precision. The upright boles of silicified trees are sporadically found at or just above this contact, and the upper few meters of the Jebel Qatrani Formation above the unconformity are commonly silicified and greatly enriched in hydrated iron minerals. The Kashab Formation is very poorly exposed north of the first breaks along the top of the Jebel Qatrani, and it is largely covered by serir and dune deposits over most of the area between Jebel Qatrani and Wadi Farîgh, located some $50 \mathrm{~km}$ to the north. The best natural exposures of the base of the Kashab Formation in the study area are preserved above the basalt immediately north, northwest, and west of Widan el Faras.

In Wadi Farîgh, continental rocks here referred to the Kashab are developed in low ridges paralleling the 
wadi, and on a few outliers in and marginal to it, notably Jebel Roussa, Garet el Raml, Jebel Geda'a, and Garet el Hamir (fig. 1B). These exposures consist principally of gravelly sandstones, red and orange mediumto coarse-grained sandstones, and red and drab mudstones that are lithologically identical to those of the Jebel Qatrani Formation. Ironstone- and silicacemented sandstones form resistant caps on some of the isolated buttes that rise above the serir, notably Garet Hamid, Garet el Raml, and Garet el Hamir (fig. 1B). The Kashab Formation is present at least as far east as Jebel Abu Roash, and it is exposed $15 \mathrm{~km}$ west of El Giza in several gravel pits (fig. 38) and pipeline trenches. The formation derives its name from the innumerable silicified logs that occur in it and are strewn across broad areas of the desert north of the Fayum Depression (Dixon, 1873; Cuvillier, 1940). Miocene fossil vertebrates were found at Wadi Farîgh in 1981 and 1983 and, as in the Jebel Qatrani Formation, rhizoliths and trace fossils are abundant.

The wholly alluvial Kashab Formation or the slightly younger fluvio-marine Moghara Formation is believed to underlie the extensive serir and dune sand deposits in the Western Desert between the Fayum Depression and Wadi Moghara (fig. $1 A$ ), some $150 \mathrm{~km}$ to the northwest. The Moghara Formation is best exposed along the low escarpment north of Wadi Moghara (Minqar Abu Dweiss-Garet Somara area), but also flanks part of the northern perimeter of the Qattara Depression (fig. $1 A$ ). In both areas, it closely resembles the Dir Abu Lifa Member of the Qasr el Sagha Formation sedimentologically and is overlain by and intertongues with the marine Miocene Marmarica Formation; however, rocks containing marine mollusks occur as far south as Wadi Farîgh. The rich Miocene mammal fauna from Wadi Moghara was originally described by Fourtau (1920).

In the western part of the Sarab Mukhafet and in the upper reaches of Wadi Kadish, uppermost Jebel Qatrani rocks merge almost imperceptibly northward with serir deposits that continue almost unbroken by good exposure for $150 \mathrm{~km}$ northwestward to Wadi Moghara. The Kashab Formation undoubtedly underlies much of this area, even though it does not appear to be present in better exposed areas west of the Fayum Depression, in the region between Madwar el Bighal and the Bahariya Oasis.

\section{SEDIMENTARY ENVIRONMENTS}

\section{QASR EL SAGHA FORMATION}

Rocks referred to the Dir Abu Lifa Member of the Qasr el Sagha Formation were separated into two facies by Vondra (1974): the interbedded claystone, silt-

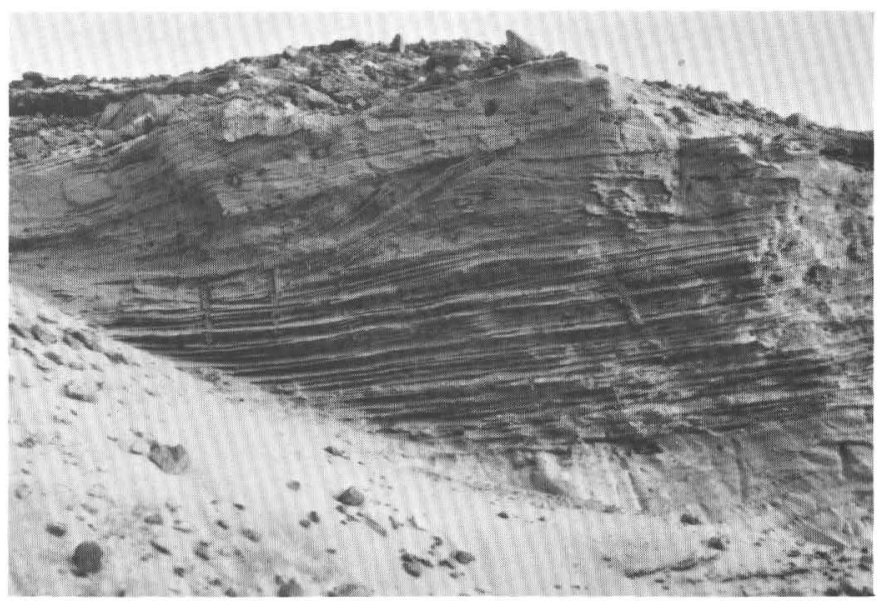

FIGURE 38.-Plane-bedded and large-scale cross-trough-stratified, medium to fine sandstones of alluvial Miocene Kashab Formation, as exposed in a sand and gravel pit, about $15 \mathrm{~km}$ west of El Giza. Middle part of cliff is about $6.0 \mathrm{~m}$ high. Note vertical and subvertical burrows that probably represent compound descending gallery systems of subterranean termites.

stone, and quartz sandstone facies and the quartz sandstone facies. The lithologies and sedimentary structures described for these facies by Vondra suggest that they represent principally the giant crossbedded sandstone sequence and the lower crossbedded sandstone and mudstone sequence, respectively, as used in this paper. Vondra believed that the interbedded claystone, siltstone, and quartz sandstone facies was deposited on a rapidly prograding delta front in quiet, shallow, brackish-marine waters. Vondra believed that his interpretation was reinforced by his identification of deposition "***on the sloping surface of the delta front" (1974, p. 89). The prograding top of this sloping surface was believed to be represented by development of the "foresets" which "****dip at less than five degrees to the northwest and [are] from 100 to $200 \mathrm{~m}$ in length" (Vondra, 1974, p. 86).

These data are indeed consistent with a delta debouching into a bay developed more or less to the north, as suggested by Vondra. However, the contrasting dip directions $\left(185^{\circ}, 229^{\circ}, 345^{\circ}\right.$, and $\left.355^{\circ}\right)$ recorded by us at localities east and west of the Qasr el Sagha Temple, our recognition of west- or west-northwest-oriented channels within this sequence, and internal (intraset) stratification showing flow directions of $255^{\circ}$ to $310^{\circ}$ $\left(45^{\circ}\right.$ to $100^{\circ}$ different from the flow direction suggested by Vondra's “****sloping surface of the delta front***) indicate a somewhat different, nondeltaic origin. McCabe (1977) described giant crossbed sets in Upper Carboniferous rocks of northern England in rocks earlier believed to be wholly deltaic in origin. These giant crossbed sets fill channels with depths up to $40 \mathrm{~m}$ and were interpreted by McCabe as having been produced 


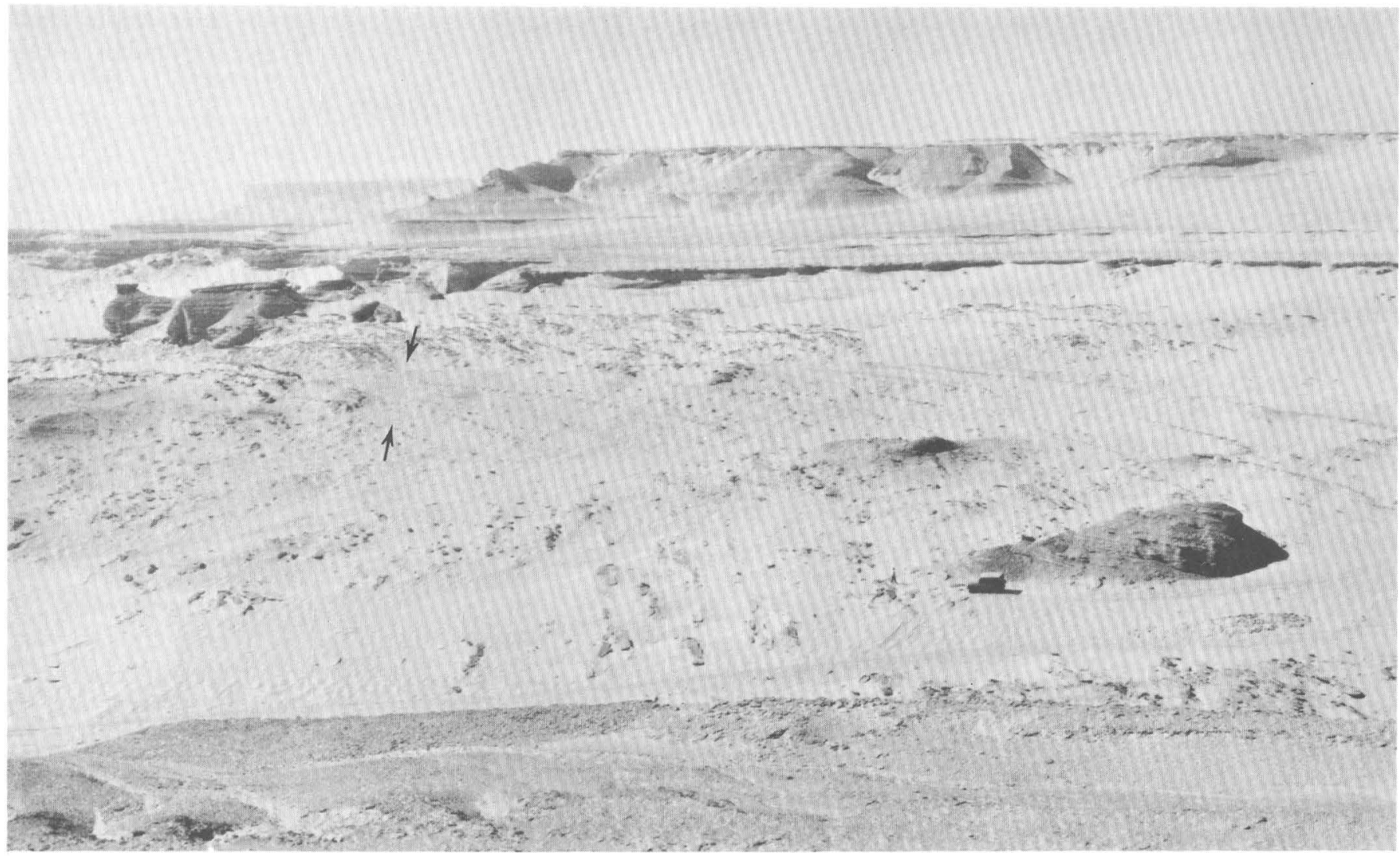

Figure 39.-Curved tops of large-scale lateral accretion surfaces exposed by deflation in middle part of the giant crossbedded sandstone sequence of the Dir Abu Lifa Member of the Qasr el Sagha Formation. Photograph taken to southwest from top of large hill, about 0.6 km north-northwest of the Qasr el Sagha Temple. Note convergence to west of curved lateral accretion surface tops (arrows).

by side-attached, alternate bars that developed in unusually deep distributary channels, rather than by deltaic slope sedimentation. The structures described by $\mathrm{McC}$ abe are quite similar to those in the giant crossbedded sandstone sequence of the Dir Abu Lifa Member of the Qasr el Sagha Formation, with one important difference: in the Upper Carboniferous example, the giant foresets dip downstream. In the Qasr el Sagha Formation, there is a $45^{\circ}$ to $100^{\circ}$ disparity between the dip directions of the giant foresets and the large-scale intrasets. This suggests that the giant cross sets in the bottom of the Dir Abu Lifa Member represent lateral accretion deposits that formed within stream channels. The exhumed tops of these deposits are visible in some large areas above the Qasr el Sagha Temple (fig. 39) and are suggestive of the "scroll tops" of other lateral accretion deposits (e.g., Puigdefabregas, 1973).

The conglomeratic coquina bed above the giant crossbedded sandstone sequence and others in the Dir Abu Lifa Member appear to us to be strandline in origin. The association of disarticulated and commonly waterworn bones, waterworn pieces of fossil wood, and densely packed accumulations of shark and ray teeth, abraded fragments of marine mollusks, and coprolites are reminiscent of reworked shoreline lags. Similar accumulations, dominated by whale, turtle, and fish remains, also are present in the Temple Member of the Qasr el Sagha Formation and in the Birket Qarun Formation west of Garet Gehannam. The lower Qasr el Sagha strandline lags contain turtle carapaces, whale and sawfish remains, internal molds of whale skulls, coprolites, and abraded and (or) rotted fossil wood. At one locality about $4 \mathrm{~km}$ east of Dir Abu Lifa, approximately 40 silicified rotten fossil logs are aligned in parallel in a probable strandline deposit rich in whale and turtle bones. These unusual deposits are generally underlain by muddy sands containing Ophiomorpha and broken crab claws and carapaces. In every instance in the Dir Abu Lifa Member, the conglomeratic coquina beds are overlain by deposits of more alluvial aspect than the beds beneath them. These relations also attest to strandline lag origins for the vertebrate coquina beds. Quite similar, though more abundant strandline lag accumulations of fossil vertebrates are developed in the lower Miocene Moghara Formation south and southeast of El Alemain. 
The lower and upper crossbedded sandstone and mudstone sequences, like the giant crossbedded sandstone sequence, consist of giant (though relatively smaller) foresets composed internally of trough and tabular cross sets and filling erosional scours. Though the crossbed sets are smaller in scale than those of the giant crossbedded sandstone sequence, the direction of flow again was to the west or west-northwest $\left(260^{\circ}-\right.$ $290^{\circ}$ on small-scale cross stratification, and $320^{\circ}$ on large-scale cross stratification). Discrepancies between the dip directions of the giant and large-scale crossstratified sets suggests that this sequence is also made up of lateral accretion deposits that accumulated in fluvial-dominated settings. The occurrence of mud drapes and of rhizoliths beneath set boundaries and within some of the large-scale crossbedded sandstones also attests to a more alluvial environment.

The rocks of alluvial aspect in the Dir Abu Lifa Member of the Qasr el Sagha Formation are separated by sequences of rock of more marine aspect. For example, the giant crossbedded sandstone sequence is separated from the lower crossbedded sandstone and mudstone sequence by four principally marine units. Similarly, the lower and upper crossbedded sandstone and mudstone sequences are separated from each other by the bare limestone sequence, and the upper crossbedded sandstone and mudstone sequence is followed by more than $270 \mathrm{~m}$ of alluvial rocks of the Jebel Qatrani Formation.

Taken in context with paleoenvironmental data from the Birket Qarun Formation and from the Temple Member of the Qasr el Sagha Formation, the temporally evolving picture of the sedimentary environment in the northern Fayum area is one of retreat of shallow seas coupled with a concomitant advance of lagoonal and lowland coastal alluvial plain environments. These changes were both gradual and sporadic in nature and appear to have consisted of at least six major and minor regressive episodes, each succeeded by major and (or) minor transgressions of the marine strand.

In figure 5, estimated stratigraphic positions recording events in this transgressive-regressive cycle are depicted for the stratigraphic column of the Dir Abu Lifa Member of the Qasr el Sagha Formation. In this scheme, the regressive changes from offshore (marine) to onshore (alluvial) conditions are marked by $\mathrm{R}$ at the left-hand margins of the columns and are coincident with strandline conglomeratic coquinas containing a high proportion of remains of terrestrial vertebrates. Transgressive peaks (maximum marine influence) are marked by $\mathrm{T}$. The hypothetical shifts from transgressive to regressive conditions are marked by $r$, and the shifts from regressive to transgressive conditions are denoted by $t$. $T$, $t$, and $r$ are commonly coincident with shelly beds and $t$ and $r$ by shells that show considerable evidence of transport and reworking (disarticulated, broken, and waterworn valves).

The earliest appearance of the coast in the immediate Fayum area during the Eocene was in Birket Qarun and (or) Temple Member time with the development of mangrove swamps and offshore subaqueous dunes in much of the region west of Garet Gehannam. Shallow marine conditions (less than $20 \mathrm{~m}$ water depth) then prevailed until deposition of the middle (or lower?) part(s) of the Temple Member of the Qasr el Sagha Formation, in which at least two major accumulations of fossil vertebrates, coprolites, and fossil trees record strand conditions and lag deposition of these constituents at or near and parallel to the ancient shoreline. The upper part of the Temple Member of the Qasr el Sagha Formation illustrates a return to nearshore shallow marine conditions, perhaps influenced by local lagoonal or offshore bar development (Vondra, 1974). A major regressive episode is marked by erosion at the base of the giant crossbedded sandstone sequence. This erosion followed the development of an east-west-aligned longitudinal trough in which accumulated more than $30 \mathrm{~m}$ of large-scale bar deposits formed by lateral accretion in streams flowing essentially southwest, south-southwest, or west. This indicates that (1) marine regression probably proceeded more or less from east to west (down the trough) in the Fayum region and (2) during this time the Fayum area was bounded on the north by a subaerial elevated area of some kind, as depicted by Salem (1976, fig. 7). Movement on a large anticline $8 \mathrm{~km}$ northeast of Widan el Faras (about $2 \mathrm{~km}$ north of Wadi el Raml) probably began just prior to deposition of the giant crossbedded sandstone sequence because this unit thins markedly north of Dir Abu Lifa and eventually pinches out across that structure to the north. Both the presence of this active anticline and a return to shallow marine conditions above the giant crossbedded sandstone sequence suggest that depression of the large east-west trough through the northern Fayum area was tectonically synclinal in origin. Succeeding regressions (with marine/alluvial strandlines marked at the bases of the gypsiferous golden sand sequence and the lower and upper crossbedded sandstone and mudstone sequences) were of progressively longer durations, culminating in the major westward withdrawal of the sea from this trough during deposition of the alluvial Jebel Qatrani Formation.

In sum, although the Birket Qarun Formation and the Temple Member of the Qasr el Sagha Formation are principally nearshore marine in origin, the coast was clearly never far from the Fayum area during any part of the late Eocene. Unusual conglomeratic coquina 
deposits, probably representing strandline lag accumulations, and mangrove swamps indicate that there was an Eocene coast in the area as early as middle Birket Qarun times and that the Fayum area was wholly emergent at least by the wane of the Eocene, when the depositional environment was dominated by fluvial processes. The change from principally marine to principally fluvial conditions that is recorded in the $77 \mathrm{~m}$ of the Dir Abu Lifa Member of the Qasr el Sagha Formation also marks the major phase of the late Eocene (and perhaps earliest Oligocene) Tethyan regression in the northern Fayum region of Egypt, a regression well recorded throughout the Mediterranean region in general. The position of the marine strand during Dir Abu Lifa time is not clear, but it probably passed west of the Fayum Depression and turned eastward somewhere north of the depression to a point well south of Cairo and around the area of shelf carbonate accumulation that is today represented by the cliffs of the Upper Mokattam Formation (Said, 1962). Structurally controlled mainland streams flowed in a trough parallel to this coast (generally westward), not more or less directly north as believed by earlier workers. This sedimentologic evidence suggests that in Dir Abu Lifa time the main entry of Egyptian interior drainage into the Tethys foredeep was from the east to an embayment in the west and that access to the nearer Tethyan coast on the north was restricted by rising anticlinal structures. This interpretation is reinforced by the continuation of a dominantly westward or southwestward course by streams of the lower part of the Jebel Qatrani Formation, as well as by the presence of widespread mangrove swamps more or less throughout the lower part of the Jebel Qatrani Formation at Madwar el Bighal and in the Sarab Mukhafet at the western edge of the Fayum Depression (Bown, 1982).

Clastic source areas for Qasr el Sagha rocks must have included Paleozoic and Mesozoic clastics as well as basement rocks from the area of El Galala el Bahariya and (or) Jebel Ataqa (fig. 1A), some $125 \mathrm{~km}$ east of the Fayum Depression in the Eastern Desert and adjoining the Red Sea (Geological Survey of Egypt, 1981). Suitable surface and (or) subsurface source rocks exist there and these were probably exposed during both the late Eocene and the lower Oligocene. Cretaceous rocks were exposed at Jebel Abu Roash anticline northwest of Cairo (fig. 1), where islands of Cretaceous clastics and carbonates were exposed in the shallow Qasr el Sagha sea (Beadnell, 1902; Said, 1962). The presence of angular feldspar clasts and the large amount of what is apparently first-cycle quartz in Dir Abu Lifa sediments preclude mainland Egypt south of the Fayum area as a major source of sediment. Though that area must have contributed something to Qasr el
Sagha deposition, most of that region during the latest Eocene was covered by newly emergent older Eocene rocks and these are dominated by shales, muds, and nonclastic rocks. Moreover, there are no suitable uplifted areas to the south that are likely clastic source areas until well into Upper Egypt in the Eastern Desert. The intervening several hundred kilometers contain few post-middle Eocene rocks and it seems to us extremely unlikely that any appreciable volume of clastic sediment was transported across this great distance to the Fayum region in the late Eocene. All of the above evidence pertaining to the sedimentology, paleoenvironments, and source areas of upper Eocene rocks in the Fayum Depression conflicts strongly with the recent resurrection of the antiquated concept of a north-flowing early Tertiary Nile River (Protonile; Kortlandt, 1980).

\section{JEBEL QATRANI FORMATION AND YOUNGER ROCKS}

The Jebel Qatrani Formation is a complex alluvial unit that is characterized by distinct large- and smallscale lateral and vertical facies changes. In general, deposition was by meandering streams and local, small-scale changes in lithology reflect shifting from one local channel environment to another and transition from channel to floodplain deposits. However, larger scale changes from east to west and upward through the section record the approach and retreat of ancient marine strandlines and the change in dominance of the depositional setting from interior alluvial to coastal floodplain, mangrove swamp, and perhaps lagoonal environments. Studies in progress of Jebel Qatrani fluvial sedimentology, paleontology, paleopedology (fossil soils), and the regional relations of the formation provide detailed insights into the nature of the nearshore alluvial systems, the climate and the paleogeography of northern Egypt during the Oligocene.

\section{ALLUVIAL SYSTEM}

Originally termed the "fluvio-marine series" by Beadnell (1905), the Jebel Qatrani Formation was demonstrated to be almost wholly fluvial in origin by Vondra (1967), Bowen and Vondra (1974), and Bown and others (1982). A freshwater alluvial environment for the bulk of the Jebel Qatrani Formation is attested to by a number of evidentiary parameters. These include its large and diverse terrestrial vertebrate fauna including several species of medium-large browsers (Simons and Wood, 1968; Bown and others, 1982) and tropical forest birds (D.T. Rasmussen and E.L. Simons, 1984 oral commun.), its both large and diverse flora of 
land plants, and the ubiquitous presence of freshwater ostracodes and charophytes in floodplain dolomitic limestones. The thin but laterally persistent nature of these carbonates as well as their ostracode fossils indicate that they formed in shallow (less than $3.0 \mathrm{~m}$ deep) freshwater floodplain ponds characterized by low salinity (R.M. Forester, in Bown and others, 1982). The floodplain deposits are formed dominantly of fine sand and mud, upon which formed spodic and ultic paleosols and inceptisols. These deposits contain innumerable rhizoliths, terrestrial invertebrate trace fossils, and local accumulations of fossil leaves, fruits, and wood. The plant fossils show that the Jebel Qatrani landscape hosted abundant and diverse vegetation and at least local areas of forest. Sedimentologic studies constitute some of the strongest evidence of the alluvial origin of most Jebel Qatrani sediments.

Notwithstanding the large body of evidence that the Jebel Qatrani Formation is almost wholly fluvial in origin, it is clear that the evolving alluvial lithotope of the Jebel Qatrani Formation always remained quite nearshore. Wing and Tiffney (1982) reported the presence of at least two components of mangrove vegetation in the Jebel Qatrani flora (Cynometra and Achrostichum) and suggested that the environment of the flora was influenced by nearby salt or brackish water. Rhizoliths of mangroves occur in the Sarab Mukhafet area and in exposures of the Jebel Qatrani Formation bordering the eastern part of the Bahariya Oasis (Bown, 1982). These trace fossils also document stream sedimentation in coastal areas. Even in the type area of the formation, occasional shark teeth, skate and ray mouthparts, and brackish-water mollusks are found; all of these fossils are evidence of marine influences and some attest to at least local areas of brackish water in Jebel Qatrani streams. As is common in coastal environments, tidal incursions and periodic coastal storms raised the salinity of streamwaters, allowing introduction of brackish water and the dispersion of marine organisms several kilometers into the interior by their following the extent of the brackish water upstream. The discovery of marine rocks in the upper part of the Jebel Qatrani Formation is another reminder that the Oligocene coast was never very far away and that the strandline fluctuated considerably. As observed above, paleocurrent azimuths on upper Jebel Qatrani rocks east of Wadi Kadish suggest strong tidal influences on stream sedimentation there.

Stream-channel deposits of the Jebel Qatrani Formation contain large- and small-scale trough and tabular cross stratification and horizontal stratification in proportions suggesting that deposition took place principally on point bars. In some areas, cross sections of epsilon cross-stratified deposits typical of point bars are well preserved and cross sections reveal whole channel geometries, demonstrating that some Jebel Qatrani streams were relatively small (about $100 \mathrm{~m}$ wide and about $15 \mathrm{~m}$ deep). Though streams contributing sediment to the gravelly sandstone sequences of the lower part of the formation may have been much wider, there is no evidence for a single major, very large, northward-flowing principal drainage such as the "UrNil" or "Protonile" suggested by many earlier authors (e.g., Unger, 1859; Blanckenhorn, 1900; Beadnell, 1905; Ball, 1939; Said, 1962; and, most recently, Kortlandt, 1980). Instead, Jebel Qatrani paleocurrent indicators show that streams flowed principally to the southwest and west and, more rarely, to the northwest.

The lower part of the Jebel Qatrani Formation is typified by multistory and multilateral gravelly sheet sandstones consisting of coalesced meander belt deposits. It contains relatively little fine sand or mudstone and has a sandstone:mudstone ratio of approximately $16: 1$. The sedimentary environment was one of highly sinuous streams which migrated laterally and reworked and winnowed out most fine overbank alluvium, resulting in a high degree of channel deposit interconnectedness. This geometry is characteristic of aggrading alluvial regimes that are influenced by a relatively stable tectonic setting (Allen, 1978; Bridge and Leeder, 1979; Kraus, 1980) and is consistent with deposition proximal to a stable or slowly retreating coastline. In the Wadi Kadish area, the lower part of the Jebel Qatrani Formation is made up almost exclusively of channel deposits, indicating even greater stream sinuosities more proximal to the Oligocene coast.

In contrast, the upper part of the Jebel Qatrani Formation is laterally and vertically more variable in lithology; it contains a much higher proportion of fine sand and overbank mudstone, and has a sandstone:mudstone ratio of about 7:1. Sand body interconnectedness appears to be about the same as that in the lower part of the formation for deposits of medium- to fine-grained sandstone, but much less interconnectedness is evident in the gravelly sandstones. This geometric difference probably reflects slightly increased rates of sediment accumulation in response to increased tectonic activity. Consequently, the meandering streams had less opportunity to laterally rework overbank sediments. The presence of several units of nearshore marine rocks at the top of the sheet-gravel sequence and in the upper variegated sequence of the upper part of the Jebel Qatrani Formation suggests that decreased channel interconnectedness in the upper part of the formation might have resulted from gradual depres- 
sion of the alluvial plain, accompanied by both an encroaching marine strand and increased tidal influence on stream sedimentation.

Salem (1976, fig. 12) depicts a northerly progradation of fan delta and slope fan deposits across the Fayum area in Oligocene times. It is emphasized that deposits of fan deltas and (or) slope fans are not present anywhere in the exposed sequence of Jebel Qatrani rocks in the Fayum Depression, and that our paleocurrent studies of Jebel Qatrani sandstones show conclusively that flow was principally to the west, not to the north as indicated by Salem. The "sandy carbonate sediments" depicted by Salem in the same figure at the western end of the Fayum Depression are seen in the field to be principally stream-laid sediments that accumulated in mangrove swamps (indicated by thick mats of mangrove rhizoliths), overlain by channel sandstones and floodplain mudstones much like those of the middle part of the Jebel Qatrani Formation elsewhere. Paleocurrent indicators demonstrate that streamflow in that area was also dominantly to the west, and we suggest that Jebel Qatrani streams were debouching into the southerly salient of a broad bay that may have separated the western area of the Fayum Depression from the Bahariya Oasis (El Bahr Depression). Mangrove rhizoliths are also abundant in the eastern Bahariya area, which might have been near the coast of this bay, and these persist eastward as far as Seton Hill east of the Bahariya Oasis.

CLIMATE

Paleosols are important indicators of paleoclimates, and those of the Jebel Qatrani Formation comprise a variety of inceptisols and relatively immature to relatively mature alluvial spodosols and ultisols. The large amounts of translocated clay, iron, aluminum, and manganese minerals in these soils, the relative abundance of hydrated iron compounds, and the pervasive development of gley mottling related to local aqueous leaching of iron pigmentation suggest that Jebel Qatrani soils were generally damp but that there were frequent intervals of good drainage. The absence of any calcrete nodules, in conjunction with well-developed clay-enriched zones and with the localized cementation of trace fossils with calcium carbonate, shows that although carbonates were available during soil development, they were unable to accumulate in the developing soil profiles except irregularly at textural boundaries or around local centers rich in decomposing organic debris (trace fossils, rhizoliths, vertebrate fossils). The restriction of carbonate sedimentation and its incorporation in fossils and the coarser sands probably reflect the greater permeability of those sediments and, hence, the relatively greater degree of ground-water movement through them. Periodically or locally wet conditions on Jebel Qatrani floodplains are also indicated by concentrations of hydrated ironstone (sometimes cementing rhizolith masses) in drab fine sandstone and mudstone situated in depressions with scoured basal contacts, and by freshwater origin floodplain carbonates. Drab, iron-oxyhydrate-rich mudstones intertongued with carbonaceous mudstones and shales rich in the leaves, stems, and fruits of plants record swampy conditions in some areas.

Localities having relatively good soil drainage (more distal on the floodplain) as well as times of relatively drier conditions in general are represented by soils having no gleyed, dehydrated iron compounds concentrated in their reddish or purple B horizons. Trace fossils of soil invertebrates occur in nearly every kind of paleosol in the Jebel Qatrani Formation, with the exception of the $\mathrm{Bt}$ and fragipan horizons of some of the ultisols. Those of both solitary and colonial insects, animals that cannot tolerate water in their nests, gallery systems, or burrows (e.g., the termites, ants, wasps, and bees) were excavated in relatively dry soils or in sandy parent materials above the ground-water table. Other organisms (e.g., crabs and crayfish) preferred damper materials for burrowing, and in general the distribution of their trace fossils reflects these preferences.

Fossil megafloras are good indicators of paleoclimates, and those of the Jebel Qatrani Formation show clear affinity to tropical Indomalaysian floras. Fossil leaves representing at least 15 species of plants in 9 families are now known in the Jebel Qatrani flora (Wing and Tiffney, 1982). The flora include Salviniaceae (Salvinia), Nelumbonaceae (Nelumbo), Sterculiaceae (Triplochiton), Leguminosae (Cynometra), Pteridaceae (Acrostichum), Ochnaceae, Sapotaceae, Typhaceae, and Palmae. Woods (Krausel, 1939; Wing and Tiffney, in Bown and others, 1982) and fruits and seeds are also preserved at several localities; the fruits and seeds are under study but appear to contain at least 25 species distributed among the Annonaceae (Annonaspermum), Burseraceae (Canarium), Icacinaceae (Icacinacarya), Menispermaceae (Eohypserpa), and Araceae (Epipremnum), among other forms. This flora shows clear affinity with the Eocene London Clay flora, and its presence indicates that the Jebel Qatrani fossil plants lived in a "tropical forest existing in a wet, perhaps monsoonal, climate" (Wing and Tiffney, 1982, p. 67). Seasonal wetness, perhaps monsoonal in nature, is also indicated by the Jebel Qatrani paleosols (Bown and others, 1982), and tropicality is suggested indirectly by the mammalian fauna, the avian fauna (D.T. 
Rasmussen, oral commun., 1984), and the trace fossils of subterranean termites (Bown, 1982).

\section{DEPOSITIONAL SETTING AND PALEOGEOGRAPHY}

Early Tertiary deposition in the Western Desert of Egypt appears to have consisted of filling of basins developed on a pre-Tertiary topography made up of eroded anticlinal and synclinal structures with a general east or northeast trend (Shata, 1953; Bayoumi and el Gamili, 1970). Folding that produced these structures probably began in the Middle Cretaceous (Shata, 1953), but continued sporadically through the Tertiary (Shata, 1953; Kostandi, 1963). Therefore, the thicknesses of early Tertiary rocks in the Fayum Depression as well as in the rest of the Western Desert of Egypt vary considerably, being thinnest across the tops of active buried structural highs and thickest in the intervening structural depressions. It seems clear that the underlying, sporadically rising structures locally controlled depositional thicknesses of the Jebel Qatrani Formation as they did rocks of the Dir Abu Lifa Member of the Qasr el Sagha Formation.

As outlined above, the Jebel Qatrani Formation is a principally alluvial deposit composed of both single and multistory sand bodies, representing channel and nearchannel deposits, and lesser amounts of mudstone, shale, and limestone which formed on floodplains. Meandering streams dominated Oligocene depositional systems in the Fayum area of Egypt, but sediment accumulation was strongly influenced by periodic oscillations of the marine strandline. Lower Jebel Qatrani rocks reflect the first major episode of terrestrial sedimentation in northern Egypt since the Late Cretaceous, and this terrestrial episode was instigated by the late Eocene Tethyan regression, an event recorded over all of the central and western Tethyan regions as well (e.g., Cavelier and others, 1981; Plaziat, 1981). Tectonic stability of the Fayum region during the waning, earliest Oligocene part of this regression is indicated by the formation of thick multistory, multilateral sand bodies in the lower part of the Jebel Qatrani Formation. These were deposited by high-sinuosity streams on a coastal alluvial plain, and most fine-grained floodplain deposits were removed by lateral reworking of the meandering channel systems. This type of deposition seems to have culminated in formation of the thick, multistory barite sandstone in about the middle of the formation, a unit developed nearly continuously for more than $70 \mathrm{~km}$ in the Fayum Depression. Paleocurrent indicators for the lower part of the Jebel Qatrani Formation indicate that these sediments were deposited by streams flowing essentially to the west or southwest, as they did during deposition of most of the Dir Abu Lifa Member of the Qasr el Sagha Formation.
This suggests that activity along the more or less eastwest-aligned trough through the Fayum area continued into the Oligocene.

Renewed advance of Tethys, heralding less stable tectonic conditions, is recorded in the middle of the Jebel Qatrani Formation by sand bodies exhibiting less channel interconnectedness than those in the lower part of the section. Paleocurrent indicators for the upper part of the Jebel Qatrani Formation show that streams had by that time developed a recurrent northwestern flow component. This probably resulted from alluvial drainage readjustment under the influence of the advancing strandline. Though deposition continued apace in the central region of the present-day Jebel Qatrani, it appears that little sediment representing the upper part of the Jebel Qatrani Formation was deposited in the area north of Wadi el Raml, between the basalt mine and the western part of Elwaht Hialla. Our field studies show that the effect of postdepositional east-west-aligned normal faulting in that area has tended to repeat several times the units in the lower part of the Jebel Qatrani section. It is unknown whether displacement on any of these faults is great enough to have faulted out the upper $190 \mathrm{~m}$ of the formation in this area, but we believe it unlikely. Rather, we suspect that the large anticline north of Wadi el Raml was an elevated area in late Jebel Qatrani time and that formational thinning in this region is due to increasingly thinner amounts of alluvial fill to the north, over the top of this structure. Though the limbs of this anticline dip quite steeply $\left(>30^{\circ}\right.$ in some areas), the structure does not affect the dip of Jebel Qatrani rocks exposed adjacent to it on either the north or the south. It is therefore likely that this anticline is the southern margin of a highland area that existed north of the present-day Jebel Qatrani during much of the Oligocene (see Salem, 1976). This highland area would have confined streamflow south of it westward, restricting access to the perhaps closer Tethyan coast on the north. Other anticlines, active during Oligocene deposition, affected the thickness of the Jebel Qatrani sequence in a narrow area about $25-32 \mathrm{~km}$ east of Wadi Kadish. There the entire formation thins to less than $100 \mathrm{~m}$ across a west-southwest trending anticline. The effect of subsurface structure on late Eocene and Oligocene deposition in the Fayum region is depicted in figure 40 .

Development of shoreline and shallow marine conditions is recorded by thin sandstones containing marine mollusks in the upper part of the formation (250-290-m levels) in the area between Widan el Faras and Tel Beadnell. This minor marine advance was closely followed by retreat of the sea, perhaps instigated by local uplifting or tilting of the northern Egyptian region, or 


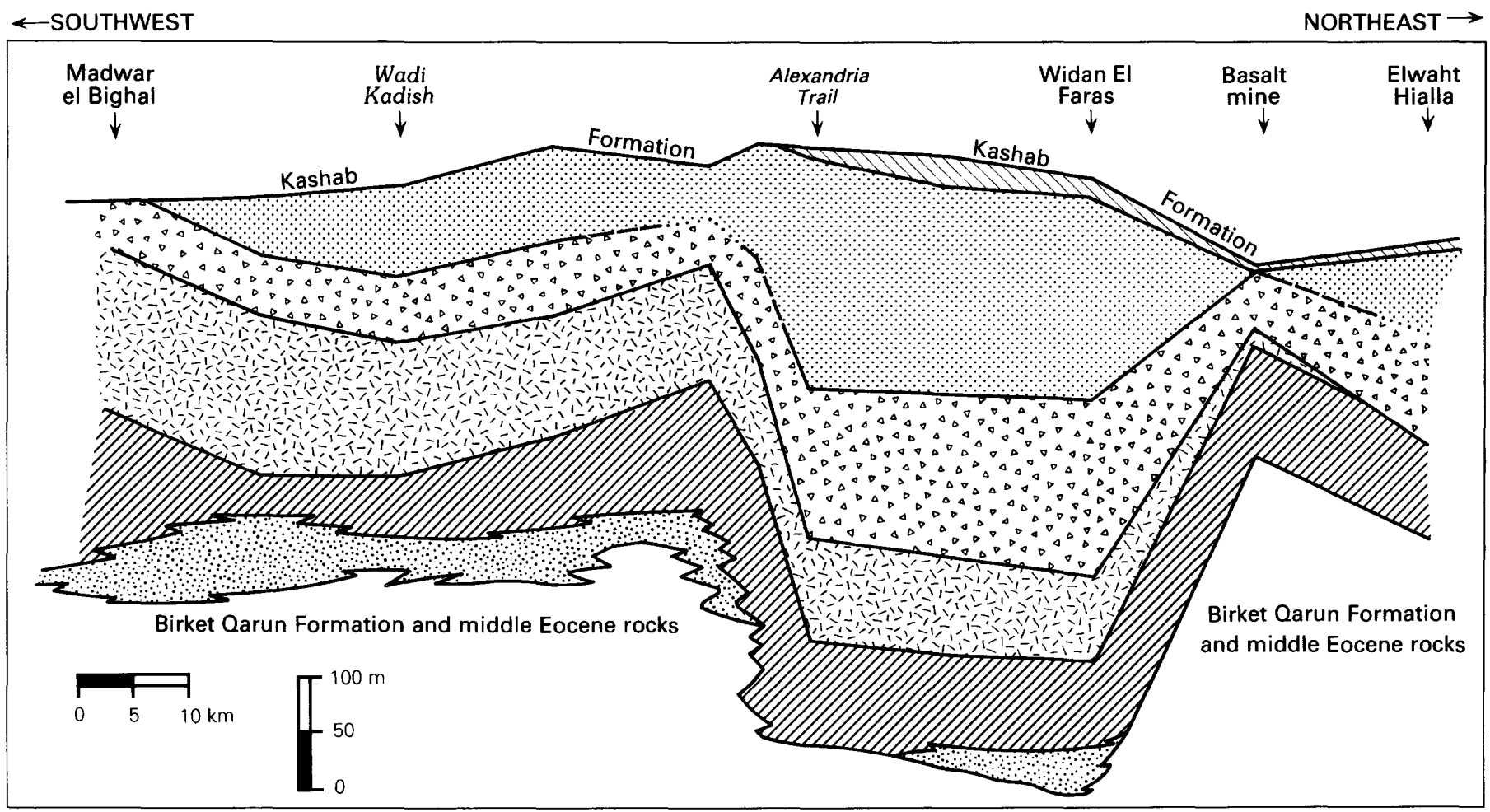

EXPLANATION

\begin{tabular}{|c|c|}
\hline & \\
\hline & tion hompong \\
\hline & $\begin{array}{l}\text { Jebel Qatrani Formation (upper part) } \\
\text { Jebel Qatrani Formation (lower part) }\end{array}$ \\
\hline
\end{tabular}

FiguRE 40.--Influence of buried Eocene and Oligocene anticlines on formation thicknesses, facies distributions, and trough of the principal early Tertiary Fayum Basin, in the region between Madwar el Bighal and Elwaht Hialla, northern Fayum Depression. Anticlines occur (1) between Wadi Kadish and the Alexandria Trail and (2) at the Basalt Mine, causing formation thinning. Principal early Tertiary Fayum Basin developed in the area between the Alexan-

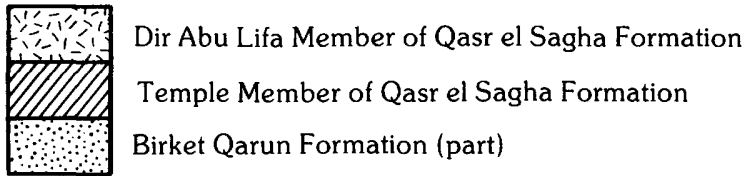

dria Trail and the Basalt Mine. Distribution of barite sandstone, which forms the contact between the upper and lower parts of the Jebel Qatrani Formation, is depicted as follows: solid line=present and well developed; dashed line=present but poorly developed; dotted line $=$ absent. Some data for Birket Qarun and Qasr el Sagha Formations provided by C.F. Vondra (written commun., 1982).

sional surface developed on the Jebel Qatrani Formation and other rocks over a wide area from the Gulf of Suez to the Fayum Depression, and perhaps as far west as the Bahariya Oasis. Rittmann (1954) believed that this volcanic activity in northern Egypt was related to renewed tension along African (northwest-trending) subcrustal lineaments, an idea also endorsed by Salem (1976). In the northern part of the Fayum Depression, these basaltic lavas make up the Widan el Faras Basalt, and they are observed to thin west of Tel Homar (fig. $2 C, D$ ) and northeast of Widan el Faras. This indicates that the local source vents are probably buried beneath serir and the Kashab Formation somewhere north or northeast of Tel Beadnell. In the Fayum Depression, the origin of the basaltic extrusions is apparently unrelated to the major east-west normal faults 
northeast of Widan el Faras, many of which displace the Widan el Faras Basalt between Wadi el Raml and Elwaht Hialla. One such fault with at least $60 \mathrm{~m}$ of displacement also offsets the Kashab Formation at a locality several kilometers northwest of Tel Homar. These relations suggest that much of the east-westtrending normal faulting is quite recent. In a few areas between Tel Beadnell and Widan el Faras, the Widan el Faras Basalt thickens and descends topographically to the south. This relationship indicates (1) that erosion prior to extrusion of the basalt was controlled by the east-west-aligned structural trough through the northern Fayum area and (2) that this trough was active as late as the time of basalt extrusion.

\section{PROVENANCE}

Several lines of geologic evidence offer information about the source of sediments of the Jebel Qatrani Formation. The clastic fraction of these rocks is overwhelmingly dominated by quartz sand. Most of this quartz is subangular to moderately well rounded, though angular clasts are certainly not rare. In the lower part of the formation, relatively coarse sands are more the rule than in the upper part of the formation. The dominance of relatively coarse quartz sand is perhaps illusory, as it might suggest that finer clastic sources were unavailable. As is generally true of alluvial systems, the finer grained sediments were deposited mostly in interchannel areas, and it has been shown that most of these deposits were reworked during Jebel Qatrani time by extensive lateral migration of stream channels. Where floodplain sediments are preserved they are dominated by sandy silt and mud. Though some of the clay in the muds might be diagenetic in origin, it is clear that most of the feldspar clasts in the sands and muds alike are unaltered. Because the quartz sand varies considerably in roundness and size (even relatively unabraded doubly terminated quartz crystals are rare clasts in some of the sandstones), it seems clear that much of the sand has been recycled from older sediments, whereas a significant remainder was derived from relatively proximal felsic igneous sources.

Thick deposits of Eocene nearshore marine rocks cover most of the Fayum region today as they did at the onset of Jebel Qatrani deposition in the latest Eocene or earliest Oligocene. Moreover, the distribution of these rocks today indicates that they must have formed most of the surface rocks between the Fayum Depression and Upper Egypt, or that in some areas they became progressively covered by Jebel Qatrani fluvial sediments. These Eocene rocks contain appreciable amounts of sandstone (generally medium- to finegrained) and therefore make up both a proximal and an obvious source for some of the finer and more mature sands, as well as for muds in the Jebel Qatrani Formation. Indeed, the Jebel Qatrani-Qasr el Sagha contact is now known to be shallowly erosional all along the Qasr el Sagha Escarpment, and the magnitude of the unconformity might well have increased southward, away from the trough area of greatest accumulation of Jebel Qatrani sediments. However, the Eocene sediments contain little coarse sand, few chert nodules, no chert pebbles, and no gravels. Pebbles and granules of light and dark brown, yellow, red, and black chert are volumetrically important clasts in the gravelly sandstones of the Jebel Qatrani Formation, and a few of these cherts contain molds of Cretaceous and Paleozoic mollusks, corals, and bryozoans. The only rocks of these ages that are likely to have been exposed in the late Eocene or early Oligocene occur east of the Fayum Depression in the Eastern Desert and far to the south in Upper Egypt (see Salem, 1976, fig. 12, for distribution of hypothetical landmasses in Egypt in late Eocene and Oligocene times).

Most early geologists who studied the continental sequence in the Fayum Depression and adjoining areas were influenced by the northern coast of present-day Egypt and by the awesome northerly flowing Nile River. Thus was born the idea that Oligocene Egypt might have been similar-that a large river (the "Ur-Nil" or "Protonile") carried sediments to the Fayum area from "the interior of a continent hundreds of miles to the south of [the] Bahariya Oasis" (Beadnell, 1905, p. 67). Said (1962), Butzer and Hansen (1968) and, most recently, Kortlandt (1980) have differed on the precise nature and location of this hypothetical southern source, but they were in general agreement that the principal areas of sediment source lay to the south. Bowen and Vondra (1974) were reluctant to endorse a "Protonile" river, but they believed that primary sedimentary structures they studied indicated north-flowing streams and that the Nubia Sandstone (Upper Cretaceous) was a likely second-cycle source because, according to Shukri and Ayouty (1953), that unit contains the greatest volume of coarse-grained sedimentary rocks in Upper Egypt.

Our paleocurrent data indicate conclusively that streams contributing sediment to the lower $160 \mathrm{~m}$ of the Jebel Qatrani Formation were flowing to the southwest or west, and that these directions changed gradually in the upper part of the section to dominantly west 
and northwest. Even in the uppermost part of the formation, adjacent to units containing marine mollusks, the principal paleoflow directions are to the west and northwest, and, immediately beneath these marine units, they show a strong southwestern component. The consistency of these measurements throughout $340 \mathrm{~m}$ of the section strongly indicates that access to the principal sediment-source areas was controlled by a large east-west-aligned trough bounded by topographic highs. Therefore, source areas lay to the northeast and east of the Fayum Depression in early Jebel Qatrani time, and these were augmented and eventually replaced by sediment sources to the east and southeast (all probably in the Eastern Desert of Egypt). The paleocurrent azimuths for the Jebel Qatrani Formation are also consonant with those obtained from the Dir
Abu Lifa Member of the Qasr el Sagha Formation, and they agree as well with the evidence from trace fossils and "reefs" of mangrove rhizoliths that, throughout most of Jebel Qatrani deposition, the most available (if not the closest) coastline lay to the west. This coast appears to have been in the vicinity of the Bahariya Oasis but might even have been more to the east, in the vicinity of the El Bahr Depression (fig. 1A). A topographically isolated coast may have been more proximal to the Jebel Qatrani area on the north. The presence of a large north-south-aligned embayment of the Tethys Sea in the area of the El Bahr Depression or perhaps northeast of the Bahariya Oasis also cannot be discounted. A hypothetical depositional model for the Fayum area of northern Egypt during the early Oligocene is depicted in figure 41 . 


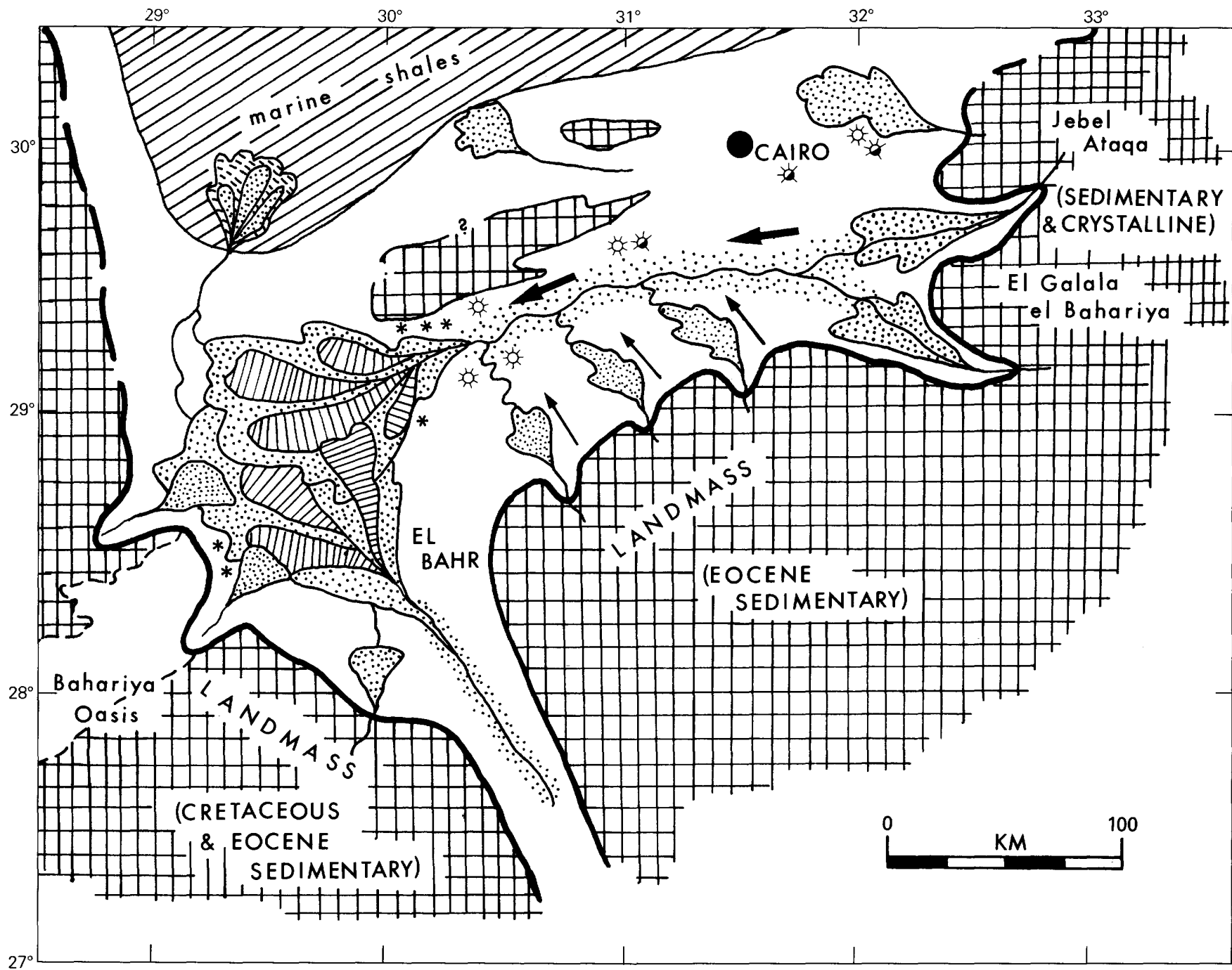

\section{EXPLANATION}

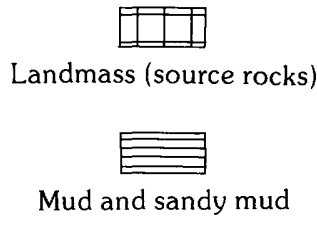

$\because \because \because \vdots$

Sand and gravel

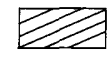

Marine shales

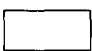

Flood plain and coastal plain, undifferentiated

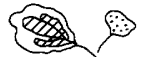

Deltas,fans
*

Rhizoliths of mangroves

20,

Rhizoliths of large trees

re

Fossil log fields

Major and minor paleocurrent trends

FIGURE 41.-Hypothetical depositional model for the Fayum Depression and adjoining areas of northern Eqypt during the early Oligocene. Stream and delta system in the El Bahr area is highly conjectural and retained from Salem (1976). Positions of Cairo and eastern part of Bahariya Oasis retained for geographical reference. (Modeled after Salem, 1976, fig. 12, but with considerable revision.) 


\section{REFERENCES CITED}

Aghion, Henri, 1940, Sur les massifs de gres et quartzites traverses par des tubes du type Gebel Ahmar: Bulletin of the Faculty of Science, Cairo University (Egypt), v. 21, p. 1-15.

Alhonen, P., Koljonen, T., Lahermo, P., and Uusinoka, R., 1975, Ferruginous concretions around root channels in clay and fine sand deposits: Bulletin of the Geological Society of Finland, v. 47, p. $175-181$.

Allen, J.R.L., 1978, Studies in fluviatile sedimentation: An exploratory quantitative model for the architecture of avulsioncontrolled alluvial suites: Sedimentary Geology, v. 21, p. 149 197.

Andrews, C.W., 1901, Preliminary note on some recently discovered extinct vertebrates from Egypt (Pt. I): Geological Magazine, v. 8, p. $400-409$.

-1903, Notes on an expedition to the Fayum, Egypt, with descriptions of some new mammals: Geological Magazine, v. 10, p. 337-343.

1906, A descriptive catalogue of the Tertiary of the Fayum, Egypt: London, British Museum Trustees, $347 \mathrm{p}$.

Attia, M.I., 1950, The geology of the iron ore deposits of Egypt: International Geological Congress, 18th, London, Proceedings, v. 13, p. 6-13.

Ball, John, 1939, Contributions to the geography of Egypt: Cairo, Survey Department, 300 p.

Ball, John, and Beadnell, H.J.L., 1903, Baharia Oasis: Its geology and topography: Cairo, National Printing Department, 84 p.

Barron, T., 1907, The topography and geology of the district between Cairo and Suez: Cairo, National Printing Department, 133 p.

Bartholemew, John \& Son, Ltd., 1978, Egypt; 1:1,000,000, World Travel Series Map.

Bayoumi, A.I., and el-Gamili, M.M., 1970, A geophysical study on the Fayum-Rayan area, with reference to its subsurface structures: Arab Petroleum Congress, 7th, Kuwait, Proceedings, v. 2 (35, B-2), p. 1-15.

Bayoumi, A.I., and Sabri, A.M., 1970, Quantitative analysis of gravity anomalies in the Qatrani-Wadi el Natrun area: Institute d'Egypte Bulletin, v. 51, p. 25-24.

Beadnell, H.J.L., 1901, The Fayum Depression: A preliminary notice of the geology of a district in Egypt containing a new Palaeogene fauna: Geological Magazine, v. 8, p. 540-546.

-1902, The Cretaceous region of Abu Roash, near the pyramids of Giza: Cairo, Survey Department, 48 p.

- 1905, The topography and geology of the Fayum Province of Egypt: Cairo, Survey Department, $101 \mathrm{p}$.

Berggren, W.A., McKenna, M.C., Hardenbol, J., and Obradovich, J.D., 1978, Revised Paleogene polarity time scale: Journal of Geology v. 86 , p. $67-81$.

Bersier, A., 1958, Sequences detritiques et divagations fluviales: Eclogia Geologia Helvetica, v. 54, p. 854-893.

Blanckenhorn, M., 1900, Neues zur Geologie und Palaontologie Aegyptens: Zeitschrift der Deutschen Geologischen Gesellschaft, v. 52 , p. $403-479$.

Bowen, B.E., 1971, Paleoenvironmental interpretations of the Oligocene Jebel el Qatrani Formation, Fayum Depression, Egypt, U.A.R.: Geological Society of America north-central section, Fifth annual meeting, Abstracts with Programs, p. 254.

Bowen, B.E., and Vondra, C.F., 1974, Paleoenvironmental interpretations of the Oligocene Gabal el Qatrani Formation, Fayum Depression, Egypt: Annals of the Geological Survey of Egypt, v. 4 , p. $115-138$.
Bown, T.M., 1979, Geology and mammalian paleontology of the Sand Creek facies, lower Willwood Formation (lower Eocene), Washakie County, Wyoming: Geological Survey of Wyoming Memoir 2, $151 \mathrm{p}$.

1982, Ichnofossils and rhizoliths of the nearshore fluvial Jebel Qatrani Formation (Oligocene), Fayum Province, Egypt: Palaeogeography, Palaeoclimatology, Palaeoecology, v. 40, p. 255-309.

1985, Maturation sequences in lower Eocene alluvial paleosols, Willwood Formation, northwest Wyoming, U.S.A., in Kraus, M.J., ed., Field Guide to Trip 2, Fourth International Conference on Fluvial Sedimentology, Fort Collins, Colo.

Bown, T.M., and Kraus, M.J., 1981, Lower Eocene alluvial paleosols (Willwood Formation, northwest Wyoming, U.S.A.) and their significance for paleoecology, paleoclimatology, and basin analysis: Palaeogeography, Palaeoclimatology, Palaeoecology, v. 34, p. $1-30$.

Bown, T.M., Kraus, M.J., Wing, S.L., Fleagle, J.G., Tiffney, B.H., Simons, E.L., and Vondra, C.F., 1982, The Fayum primate forest revisited: The Journal of Human Evolution, v. 11, p. 603-632.

Bown, T.M., and Simons, E.L., 1984, First record of marsupials (Metatheria: Polyprotodonta) from the Oligocene in Africa: Nature, v. 308 , p. $447-449$.

Brammer, H., 1968, Decalcification of soils developed in calcareous Gangetic alluvium in East Pakistan: Pakistan Journal of Soil Science, v. 4, p. 8-20.

Bridge, J.F., and Leeder, M.R., 1979, A simulation model of alluvial stratigraphy: Sedimentology, v. 26, p. 617-644.

Bridges, E.M., 1978, World soils: Cambridge, Cambridge University Press, $128 \mathrm{p}$.

Butzer, K.W., and Hansen, C.W., 1968, Desert and river in Nubia: Madison, University of Wisconsin Press, 562 p.

Carlisle, F.J., Knox, E., and Grossman, R., 1957, Division V-Soil genesis, morphology and classification: Fragipan horizons in New York soils; I-General characteristics and distribution: Soil Science Society of America Proceedings, v. 21, p. 320-321.

Carruthers, W., 1870, On the petrified forest near Cairo: Geological Magazine, December 1870, p. 306-310.

Caton-Thompson, G., and Gardner, E.W., 1934, The Desert Fayum: London, Royal Anthropological Institute of Great Britain and Ireland ( 2 vols.), $167 \mathrm{p}$.

Cavelier, C., Chateauneuf, J.-J., Pomerol, C., Rabussier, D., Renard, M., and Vergnaud-Grazzini, C., 1981, The geological events at the Eocene/Oligocene boundary: Palaeogeography, Palaeoclimatology, Palaeoecology, v. 36, p. 223-248.

Cuvillier, J., 1940, L'Oligocene du Gebel Kashab (Desert Lybique): Comptes Rendus Academie des Sciences Paris,v.210, p.340-342.

Daniels, R.B., Nettleton, W.D., McCracken, R.J., and Gamble, E.E., 1966, Morphology of soils with fragipans in parts of Wilson County, North Carolina: Soil Science Society of America Proceedings, v. 30, p. 376-380.

Dixon, W., 1873, A petrified forest in the Libyan Desert: Nature, March 13, 1873, p. 363-364.

Faris, M.I., Farag, I.A.M., and Gheith, M., 1956, Contributions to the geology of Bahariya Oasis: Abstracts of the Proceedings of the Geological Society of Egypt, v. 2, p. 36-38.

Fleagle, J.G., Bown, T.M., Obradovich, J.D., and Simons, E.L., in press, How old are the Fayum primates? Congress of the International Primatological Society, 10th, 1985, Proceedings.

Fleagle, J.G., Simons, E.L., and Conroy, G.C., 1975, Ape limb bone from the Oligocene of Egypt: Science, v. 189, p. 135-137. 
Fourtau, Rene, 1894, Etude geologique sur le Gebel Ahmar: Bulletin de l'Institute Egyptien, ser. 3, no. 5, p. 377-386.

- 1920, Contribution a l'etude des vértebrès miocenes de l'Egypte: Cairo, Government Printing Office, $122 \mathrm{p}$.

Friend, P.F., Slater, M.J., and Williams, R.C., 1979, Vertical and lateral buildings of river sandstone bodies, Ebro Basin, Spain: Journal of the Geological Society of London, v. 136, p. 39-46.

Geological Survey of Egypt, 1981, Geologic Map of Egypt.

Hardie, L.A., 1970, Algal structures in cemented crusts and their environmental significance, in Hardie, L.A., ed., Sedimentation on the modern carbonate tidal flats of northwest Andros Island, Bahamas: Johns Hopkins University Studies in Geology 22, p. $159-177$.

Hayasaka, I., 1935, The burrowing activities of certain crabs and their geologic significance: American Midland Naturalist, v. 16, p. 99-103.

Kelly, S.R.A., and Bromley, R.G., 1984, Ichnological nomenclature of clavate borings: Palaeontology, v. 27, p. 793-807.

Kortlandt, Adriaan, 1980, The Fayum primate forest: Did it exist? The Journal of Human Evolution, v. 9, p. 277-297.

Kostandi, A.B., 1963, Eocene facies maps and tectonic interpretation in the Western Desert, U.A.R.: Revue de l'Institute Francais du Pétrole, v. 18: p. 1331-1343.

Kraus, M.J., 1980, Genesis of a fluvial sheet sandstone, Willwood Formation, northwest Wyoming, in Gingerich, P.D., ed., Early Cenozoic paleontology and stratigraphy of the Bighorn Basin, Wyoming, 1880-1980; University of Michigan Papers on Paleontology, v. 24 , p. $87-94$.

__ 1985 , Sedimentology of Early Tertiary rocks, northern Bighorn Basin, in Kraus, M.J., ed., Field Guide to Trip 2, International Conference on Fluvial Sedimentology, 3d, Fort Collins, Colo., p. 26-33.

Kraus, M.J., and Bown, T.M., 1982, Alluvial paleosols: Recognition and significance for paleoenvironmental reconstruction and basin analysis: International Association of Sedimentologists Annual Meeting, Hamilton, Ontario, 1982, Abstracts, p. 13.

_- in press, Paleosols and time resolution in alluvial stratigraphy, in Wright, P.V., ed., Palaeosols: Their recognition, classification, and interpretation: London, Blackwell, and Princeton, N.J., Princeton University Press Geology Series.

Krausel, R., 1939, Ergbnisse der Forschungreisen Prof. E. Stromer's in den Wusten Agyptens, IV. Die fossilen Floren Agyptens: Abhandlungen der Bayerischen Akademie der Wissenschaften Mathematische-Naturwissenschaften Abteilungen, Neue Folge, v. 47, p. $1-140$.

MacDonald, D.I.M., and Jefferson, T.H., 1985, Orientation studies of waterlogged wood: A paleocurrent indicator? Journal of Sedimentary Petrology, v. 55, p. 235-239.

McCabe, P.J., 1977, Deep distributary channels and giant bedforms in the Upper Carboniferous of the Central Pennines, northern England: Sedimentology, v. 24, p. 271-290.

Meneisy, M.Y., and el-Kaliuobi, B.A., 1975, Isotopic ages of the volcanic rocks of the Bahariya Oasis: Annals of the Geological Survey of Egypt, v. 5, p. 119-122.

Meneisy, M.Y., and Kreuzer, Hans, 1974, Potassium-Argon ages of Egyptian basaltic rocks: Geologisches Jahrbuch, v. 9, p. 21-31.

Newbold, L., 1848, On the geological position of the silicified wood of the Egyptian and Libyan Deserts, with a description of the "petrified forest" near Cairo: Quarterly Journal of the Geological Society of London, v. 4, p. 349-357.

Omara, S.M., and Sanad, Selim, 1975, Rock stratigraphy and structural features of the area between Wadi el Natrun and the
Moghra Depression (Western Desert, Egypt): Geologisches Jahrbuch, v. 16, p. 45-73.

Orlebar, A.B., 1845, Some observations on the geology of the Egyptian Desert: Journal of the Bombay Branch of the Royal Asiatic Society, v. 2, p. 229-251.

Plaziat, J.-C., 1981, Late Cretaceous to late Eocene palaeogeographic evolution of southwest Europe: Palaeogeography, Palaeoclimatology, Palaeoecology, v. 36, p. 263-320.

Puigdefabregas, Cayo, 1973, Miocene point bar deposits in the Ebro Basin, northern Spain: Sedimentology, v. 20, p. 133-144.

Rittmann, A., 1954, Remarks on the eruptive mechanism of the Tertiary volcanoes of Egypt: Bulletin of Volcanology, v. 15, p. 109117.

Said, Rushdi, 1962, The geology of Egypt: Amsterdam, Elsevier, $377 \mathrm{p}$.

1981, The geological evolution of the River Nile: New York, Springer-Verlag, $151 \mathrm{p}$.

Salem, Rafik, 1976, Evolution of Eocene-Miocene sedimentation patterns in parts of northern Egypt: American Association of Petroleum Geologists Bulletin, v. 60, p. 34-64.

Savage, D.E., and Russell, D.E., 1983, Mammalian paleofaunas of the World: London, Addison-Wesley, $432 \mathrm{p}$.

Selley, R.C., 1969, Near shore marine and continental sediments of the Sirte Basin, Libya: Quarterly Journal of the Geological Society of London, v. 124, p. 419-460.

Shata, A., 1953, New light on structural developments of the Western Desert of Egypt: Institute Désert Egypte Bulletin, v. 3, p. 101-106.

Shazly, E.M. el, Hazek, N.M.T. el, Monem, A.A., Khawasik, S.M., Zayed, Z.M., Mostafa, M.E.M., and Morsi, M.A., 1974, Origin of Uranium in Oligocene Qatrani sediments, Western Desert, Arab Republic of Egypt, in Formation of Uranium ore deposits; sedimentary basins and sandstone-type deposits; sedimentary deposits in other areas, Proceedings of I.A.E.A. 2(STI Pub. 374): p. 467-478.

Shukri, N.M., 1953, The geology of the desert east of Cairo: Institute Désert Egypte Bulletin, v. 3, p. 89-105.

Shukri, N.M., and Akmal, M.G., 1953, The geology of Gebel elNasuri and Gebel el-Anqabiya district: Societe de Géographie d'Egypte,"v. 26, p. 243-276.

Shukri, N.M., and Ayouty, M.K., 1953, The mineralogy of the Nubian Sandstone in Aswan: Institute Désert d'Egypt Bulletin, v. 3, p. $65-88$.

Simons, E.L., 1961, An anthropoid mandible from the Oligocene Fayum beds of Egypt: American Museum Novitates 2051, p. 1-5. 1962, Two new primate species from the African Oligocene: Postilla 64, p. 1-12.

-1974, (Parapithecidae: Old World Higher Primates): New species from the Oligocene of Egypt and the initial differentiation of the Cercopithecidae: Postilla 166, p. 1-12.

Simons, E.L., and Bown, T.M., 1984, A new species of Peratherium (Didelphidae: Polyprotodonta): The first African marsupial: Journal of Mammalogy, v. 65, p. 539-548.

-1985, Afrotarsius chatrathi, first tarsiiform primate (?Tarsiidae) from Africa: Nature, v. 313, p. 475-477.

Simons, E.L., and Kay, R.F., 1983, Qatrania, new basal anthropoid primate from the Fayum, Oligocene of Egypt: Nature, v. 304, p. 624-626.

Simons, E.L., and Wood, A.E., II, 1968, Early Cenozoic mammalian faunas, Fayum Province, Egypt: Peabody Museum of Natural History (Yale) Bulletin 28, 105 p. 
Soil Survey Staff, 1975, Soil Taxonomy: U.S. Department of Agriculture Soil Conservation Service Agricultural Handbook 436, $754 \mathrm{p}$.

Tarling, D.H., and Mitchell, J.G., 1976, Revised Cenozoic polarity time scale: Geology, v. 4, p. 133-136.

Unger, F., 1859, Der versteinerte Wald bei Cairo und einige andere Lager verkeiselten Holzes in Agypten: Sitzungsberichte der Mathematisch-Naturwissenschaftlichen Classe der Kaiserlichen Akademie der Wissenschaften (Wein), v. 33, p. 209-233.

Vondra, C.F., 1967, Stratigraphy of the Upper Eocene and Oligocene deposits in the Fayum Depression: Geological Society of America Annual Meeting, 1967, Abstracts with Programs, p. 229.
1971, Upper Eocene transitional and nearshore marine deposits, Fayum Depression, Egypt, U.A.R: Geological Society of America north-central section, Fifth Annual Meeting, Abstracts with Programs, p. 285-286.

1974, Upper Eocene transitional and near-shore marine Qasr el Sagha Formation, Fayum Depression, Egypt: Annals of the Geological Survey of Egypt, v. 4, p. 79-94.

Wing, S.L., and Tiffney, B.H., 1982, A paleotropical flora from the Oligocene Jebel Qatrani Formation of northern Egypt: A preliminary report: Miscellaneous Series of the Botanical Society of America, v. 162, p. 67. 


\section{GLOSSARY}

Bahariya (baharia)

Bahariya Oasis

Bahr Youssef

Birket

Birket Qarun

Dir (deir)

Dir Abu Lifa

Elwaht Hialla

Ekhwat el Talata, El

Etnain Efreet

Galala el Bahariya, El

Garet (gar, garat, qaret)

Garet el Esh

Garet Gehannam (Gahannam)

Garet el Ghaziya

Garet el Gindi

Garet Hamid

Garet el Hamir

Garet el Hamra

Garet Harra

Garet Maghnini

Garet el Raml

Garet Somara

Garet Umm el Zalat

Gedida
North

North Oasis

Joseph's canal

Lake

Lake of the Horn

Church

Church of the Father of Leaves (P.D. Gingerich and E.L. Simons (oral commun., 1983) observed that Dir Abu Lifa is misplaced on all extant maps of the Fayum region. The correct location is about $3.0 \mathrm{~km} \mathrm{~N}$. $57^{\circ}$ $\mathrm{E}$. of where it is shown on all other maps.)

Hill (of the boy) Hialla

The three sisters

The two ghosts

Northern Galala plateau (eminence)

Hill; generally flat-topped

Hill of the Nest

Hill of Hell

Hill of the Gypsy Woman

Hill of the Soldier

Hamid's Hill

Hill of the Donkeys

Red Hill

Hill of the Cat

Hill of the Crazy Men

Hill of Sand

Hill of the Black Man

Hill of the Mother of Boulders

New
Ghard

Ghard el Hineishat

Ghard el Qattiniya

Jebel (djebel, gebel, gabal)

Jebel Geda'a

Jebel Ghorabi

Jebel Qatrani

Jebel Roussa

Kashab

Madwar el Bighal

Minqar abu Dweiss

$\mathrm{Naqb}$

Naqb el Garw

Qasr

Qasr el Sagha

Sarab Mukhafet

Serir

Tel

Tel Akgrab

Tel Beadnell

Tel Beradt-shay

Tel Comfessa

Tel el Eswid

Tel Homar

Tel Markgraf

Tel Taleb

Tel Torisha

Wadi

Wadi Efreet

Wadi Farîgh

Wadi Ghorab

Wadi Kabir

Wadi Kadish

Wadi Moghara

Wadi el Raml

Widan el Faras

Yardang
Large dune (commonly a seif)

Hineishat's dune

Dune of Cotton

Ridge, cliff

Cliff of the Grandfather

Crow Ridge

Tar Ridge

Rice Ridge

Wood

Yoke of the Mule

The Bird's Beak

Pass

Pass of the Small Dog

Temple

Temple of the Goldsmith

Mirage Basin

Pebble desert

Hill

Scorpion Hill

Beadnell's Hill

Teapot Hill

Scarab Hill

Black Hill

Donkey Hill

Markgraf's Hill

Fox Hill

Hill of the Horned Viper

Ravine or watercourse, generally dry

Ghost Wadi

Empty Wadi

Wadi of the Crows

Big Wadi

Chaotic Wadi

Moghara Wadi

Wadi of Sand

Ears of the Mare

Elongate, wind-sculptured hill 


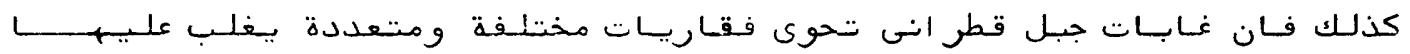

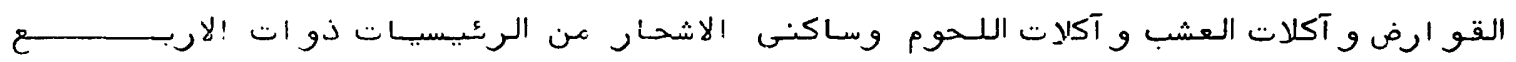
• المتقـدمة كالـقرود

هذ ا وقد تتم تحديد أحيـاء كثيرة من اللافقـاريبات بو اسطة آثنار حفربيـت وكذلهـك الدبـور والنمل وجر اد البـحر والنمل الاسود والنمل الابسيض الذى يـعبيش تتحت الارض .

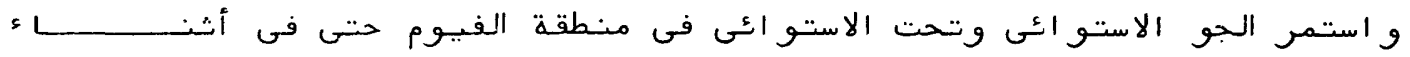

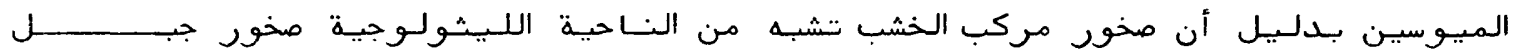
قطر انس المتكونة أو اخر الاولـبـوسين و أو ائل الميوسين ، حيـث كانت الر سوبيـات قــ ملاء ت حوض الفيوم ، و أخير ا استطلاعت الانـهار أن تصب فى بحر التيشى من الجنوب مـــن حين لا خَر وفى أمـاكن محددة كـان البحر يـغزو الارض، أشنـاء الميوسين حتى زمن وســـــ

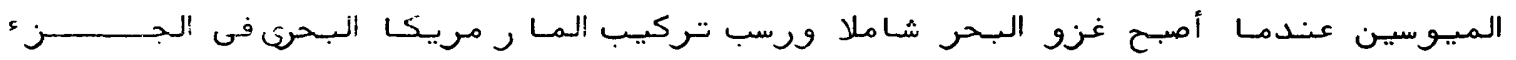
• الشمـالى من الصحر اء الغربية 
وهذ ا دلسيل و اضح على أن منـاطق الترسيب الاصلـية لهذه الصخور توجد فى متـــاول اليد اكثر من تلك الو اقعة على بعد مئسات الكيلـومتر ات فى مصر العليـ والتى اقترحها كل من عمل سابقـا

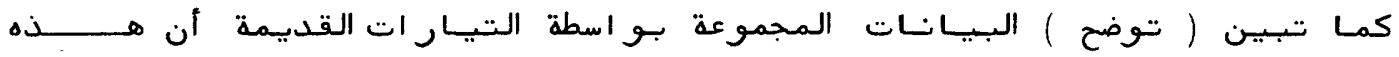
المصادر الاملية قد تنقع الى الشرق من منخفض الفيوم ، ويحتمل أن تكون قـريبة مــــن

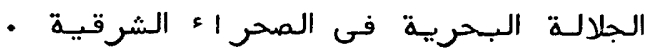

و أثنـاء فترة الاولـيجوسين كانت منطقة الفيوم عبـارة عن شاطىء سهلى منخف فـ ذات منـاح استو ائى وشبه استو ائى تميز بـوفرة و اختلاف أنو اع النبـاتـات •

وكانت المستـققعات الاستو ائية تنطفى على الشريط الساحلى التـابع لـلاولـيجوســــين ثم بعد ذلك لـدخول الغـابـات الذى يـعم تو اجد أنو اع مختلـفة من الاشجار مثع الكرمـة

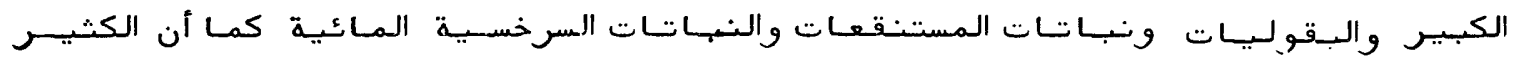
من تلكك العنـاصر النبـاتيـة الاقليمية تشبه الاجنـاس الاستو ائية وشبه الاستو ائية فـى

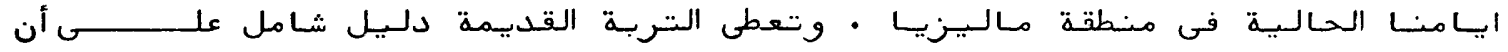
التربة رطبه ولكنها توضح أن سقوط الامطار كان موسمى تتقريبـا

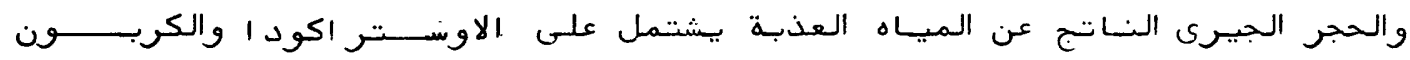
المشع الذى أمكن بـو اسطتهها تسجيل تكوين شريط سهول فيضية محلية كبيرة . وتلــــك الار اضى الشاطئية المنخفضة قد تحطمت بو اسطة تفرعات نهرية كثيرة والتى تنتسهى فـى اتجاه الغرب والشمال الغربى ، وبعيد ا شيكامـا عن اتجاه البحر التيسى •

السهل الفيضى به تضاريس بسيطة ، وعو اصف تكون المد الذى يدخل الميـاه المـالـحـة فى مجرى النهر لـمسافة عدة كيلـو متر ات على الارض خشية تز اوج الاسمـاك البحريـــــة وسملك القرش والدرنك والشعاعيـات والرخويـات والقشريـات وكذلك التمـاسيح وسلاحف الميــــاه العذبة و الاسماك والرخويـات 
هذا والتـآكا، المتتـابع قد أثير بو اسطة رفع محلى أوظـى عام للسهول المـاعيـة

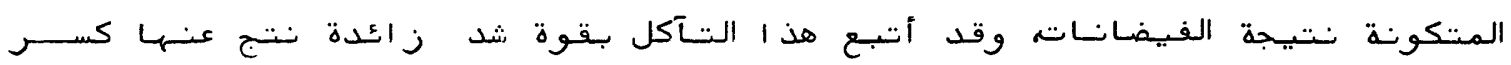

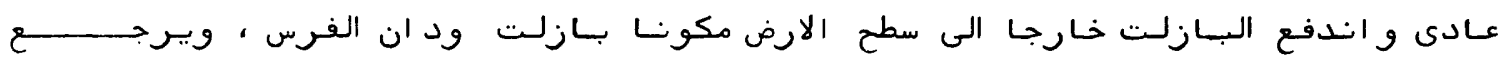

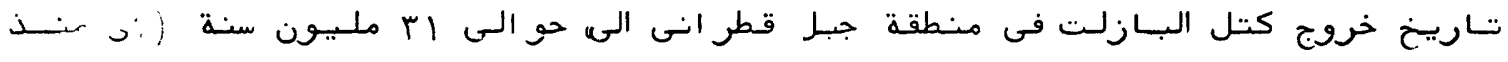

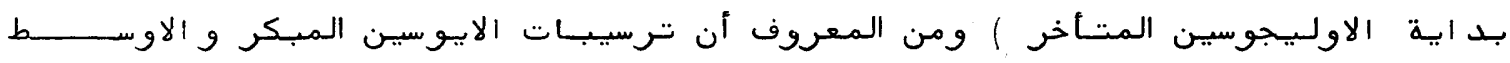

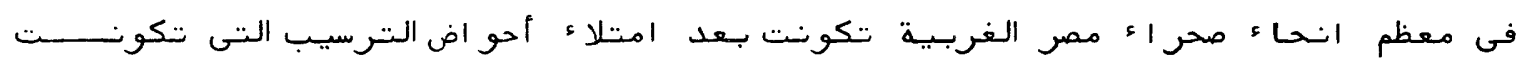
أشنـاء العصر الكريتتـاوى المتـاخر • وقد ملسكت معظم الاحو اض الترسيبيـة المتكونة علـى رفوف البحر التيسى العظيم مع نهاية الايوسين الاوسط . وبـالرغم من أن هذا البحث يقترح أن اتجـاه الخط الرئيسى الذى يـقمم حوض الترسيب فى منطقة الفيوم هو غرب / جنوب غرب ، شرق / شمال شرق فقد بقيت المنطقة نشـــة أو على الاقل استمرت تستقبل سمك غير عادى من الترسيبـات أشنـاء الايبوسين المتـأخـر و الاولـيـجوسين المبكر

ونظر ا لان صخور الايوسين المتـاخر و الاولـيجوسين المبكر يقل سمكها كلمـا اتجهنـا شمالا ، وكذلك لان المعلـومـات القديمة توضح أن تلكك الترسيبـات تكونت نتيجة اندفــاع المجارى المـائية كالـجد اول و الانهار تجاه الغرب ، كما أن حوض الفيوم كان قد انفصل

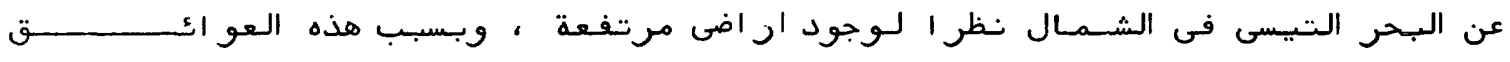

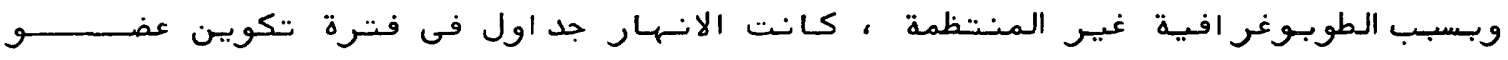

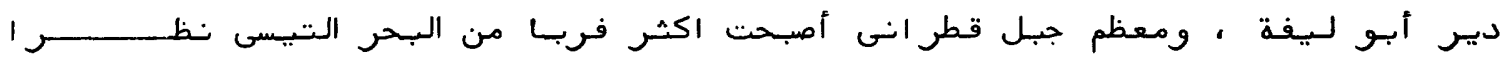

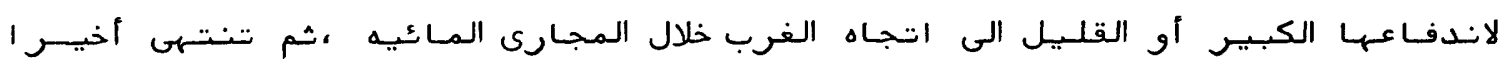

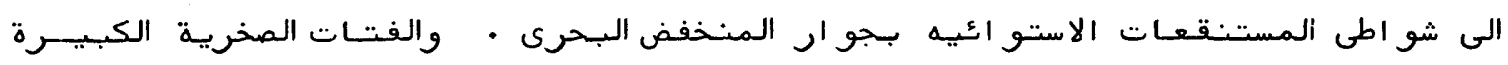
فى عضو دير أبو لـيفه التـابـع لـتكوين قصر الصاغة والتى يفلب على تركيبسها الرملـــى

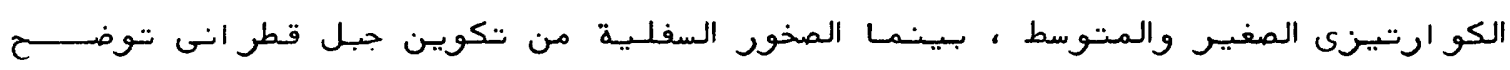

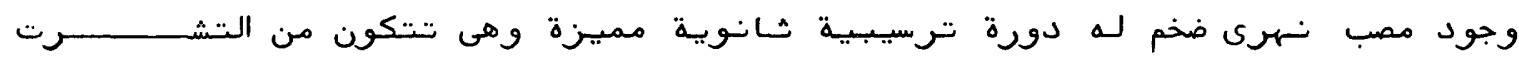
وحصى ، وكذلك من فتـات مخرية أولـية | تشمل نسبيا على بلوررات فلـسبـار متجويـــة أو مسحوجة ) وهى مشتقة من الصخور النـاريـة المحتويـة على فلســـبــارات . 


\section{بسم اللهه الرحمن الرحيم}

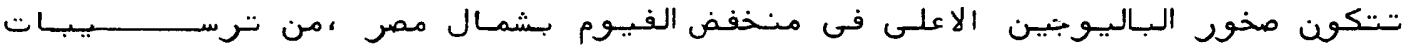
شاطئيه وترسيبـات نهريه مكونة تكوين قصر الصاغة الذى يـنتمى الى الايبوسين العلــوى،

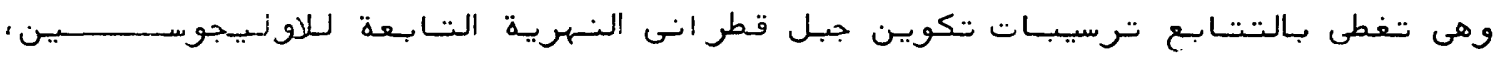
وكذلك بـازلت ود ان الفرس • والجزء العلـوى لـتكوين قصر الماغة ( عضو دير ابولسيفة ) بنفس المنطقة يتكون من VV متر ا من ترسيبـات الحجر الرملهى وكذلك ترسيبـات متر اكمة

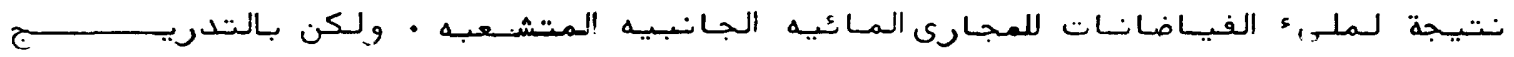
تـر اجع البحر إلتيـثى أثتـاء الايوسين المتـأخر وتلا ذلك تقدم السهول الفيسضانيه فــى

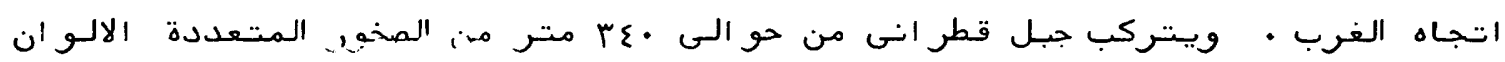
المتكونة بالفيضانـات المـائية مثل الحجر الرملى الصغير والكبير الحبيبـات ألتى تصل الـى لى

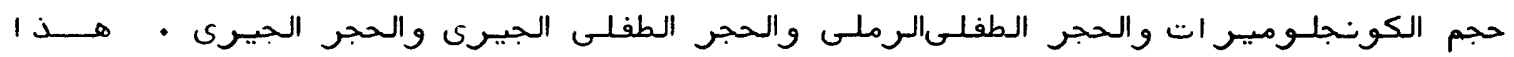

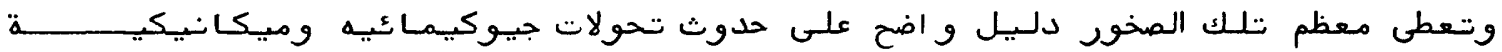
عميقه وكثيرة ترجع الى تكوين التربة القديمة

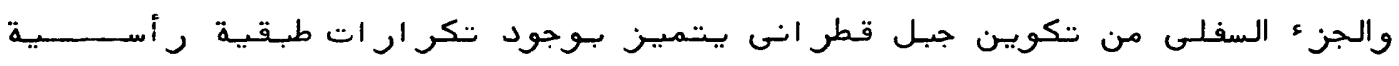
كثيرة وكتل رملـية جـانبيه متعدده وهذ ا يؤكد أن الترسيبـات حدثت بو اسطة التفرعـات النهريـة وتحت ظروف هـادئة من الحركات الارضية وعلى عكس ذلك فـان الجزء العلـوى مـــن تكوين جبل قطر انى يشتمل على نسبة عظيمة من الحجر الرملى النـاعم والحجر الطفلــــى وعدد من الكتل الرملية غير المتتـابعة ، وهذا بهعزى الى ترسيب فى ظروف اكثر نشاطا للحركات الارضية وكذلك تحت تـأثير تتعدى البحر على الشاطىء

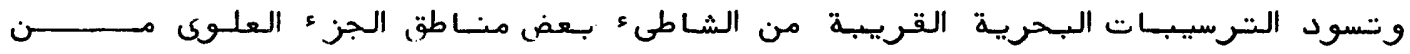

تكوين جبل قطر انى ، ولـكن هذ ا التقدم كان نـادر ا و استمر لـفترة قصيرة ثم اتبســع أولا بـانقلابه الى ترسيبات ماعية ثم بعد ذلك تبعة تـآكل كلى . 